\title{
CARACTERIZAÇÃO DA RAÇA NELORE E TESTE DE PATERNI- DADE POR MARCADORES MOLECULARES
}

\author{
ARTUR JORDÃO DE MAGALHÃES ROSA \\ Zootecnista
}

Orientador: Prof ${ }^{\circ}$. $\mathrm{Dr}^{\circ}$. Irineu Umberto Packer

Dissertação Apresentada à Escola Superior de Agricultura "Luiz de Queiroz", da Universidade de São Paulo, para obtenção do Título de Mestre em Agronomia, Área de Concentração: Ciência Animal e Pastagens.

\section{PIRACICABA}

Estado de São Paulo - Brasil

Janeiro - 1997 


\section{Dados Internacionais de Catalogação na Publicação (CIP) DIVISÃo DE BIBLIOTECA E DOCUMENTAÇĀO - Campus "Luiz de Queiroz"/USP}

Rosa, Artur Jordão de Magalhães

Caracterização da raça nelore e teste de paternidade por marcadores moleculares / Artur Jordão de Magalhães Rosa. - - Piracicaba, 1997.

114 p. : il.

Dissertação (mestrado) - Escola Superior de Agricultura Luiz de Queiroz, 1997. Bibliografia.

1. Gado nelore 2. Melhoramento genético 3. Método estatístico 4. Marcador molecular I. Título

CDD 636.291

636.2082 


\title{
CARACTERIZAÇÃO DA RAÇA NELORE E TESTE DE PATERNI- DADE POR MARCADORES MOLECULARES
}

\author{
ARTUR JORDÃO DE MAGALHÃES ROSA
}

Aprovada em: 21/ 03/ 1997

Comissão julgadora:

Prof. Dr. Irineu Umbert Packer

Prof. Dr. Luiz Lehmann Coutinho

Dr. Alexander George Razook
ESALQ/ USP

ESALQ/ USP

IZ/ Sertãoziho

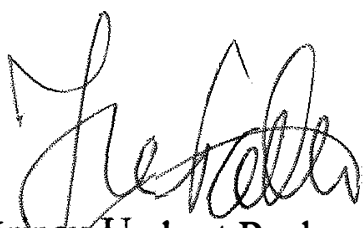

Prof. Dr. Irngy Umbert Packer

Qrientador 
A minha namorada pelo apoio e toda a felicidade que tem me dado.

A minha mãe pelo carinho, incentivo e esforço desempenhado na minha educação pessoal e formação escolar.

Dedico este trabalho 


\section{AGRADECIMENTOS}

- Ao Prof. Dr. Irineu Umberto Packer, pela orientação, disponibilidade, auxílio na elaboração desta dissertação e amizade, qualidades que tornam mais agradáveis os anos de convivência;

- Ao Prof. Dr. Luiz Lehmann Coutinho, pela importante e indispensável colaboração e estímulo ao meu aprimoramento quanto às atividades laboratoriais;

- Ao Prof. Dr. Roland Venkovsky, pelas sugestões durante a elaboração do projeto de dissertação;

- Aos professores do Dept ${ }^{\circ}$ de Zootecnia, pelos ensinamentos recebidos;

- À ESALQ- Escola Superior de Agricultura "Luiz de Queiroz", pela oportunidade de realizar este curso de Pós-graduação;

- Ao IZ- Instituto de Zootecnia de Sertãozinho e, em especial aos Pesquisadores Alexander George Razook e Leopoldo Andrade Figueiredo, pelo apoio necessário à elaboração deste projeto;

- Aos técnicos do laboratório de Biotecnologia Animal (Mário, Maria Antônia e Nirlei), pelo auxílio na execução dos trabalhos experimentais e amizade compartilhada;

- Aos colegas de Pós-Graduação e, em especial, Fábio, Marcos e Rodrigo, pela amizade e ajuda quando esta foi necessária;

- Aos amigos e familiares pelo estímulo;

- Ás secretárias do Departamento de Zootecnia, Claudia e Vera, e da Pós Graduação, Celine, Silvia, Maria Helena, Luia, Stela, Marisa, Edilma, Lia, pela disponibilidade e atenção;

- À todos aqueles que de alguma forma contribuíram na elaboração e execução deste trabalho;

- À Capes, pela concessão de bolsa de estudos. 


\section{SUMÁRIO}

LISTA DE TABELAS V V

LISTA DE FIGURAS vii

RESUMO IX ix

SUMMARY Xi

1- INTRODUÇÃO 1

2- REVISÃO DE LITERATURA 3

2.1- A RAÇA NELORE 3

2.1.1- Nomenclatura e Taxonomia 3

2.1.2- Origem e Domesticação 4

2.1.3- Introdução do Nelore no Brasil 5

2.1.4- Aspectos Gerais da Raça Nelore $\quad 6$

2.1.5- Situação Atual

2.2-DESENVOLVIMENTO DA GENÉTICA $\quad 8$

2.2.1- Grandes Descobertas na História da Genética $\quad 8$

2.2.2-Marcadores Genéticos 11

$\begin{array}{ll}\text { Marcadores Morfológicos } & 12\end{array}$

$\begin{array}{ll}\text { Marcadores Bioquímicos } & 12\end{array}$

Antígenos Eritrocitários $\quad 13$

2.2.3- Marcadores Moleculares $\quad 14$

$\begin{array}{ll}\text { RFLP } & 14\end{array}$

$\begin{array}{ll}\text { Minissatélites } & 15\end{array}$

$\begin{array}{ll}\text { RAPD } & 16\end{array}$

$\begin{array}{ll}\text { Microssatélites } & 17\end{array}$

$\begin{array}{ll}\text { Polimorfismo de Conformação } & 19\end{array}$ 
2.3- USO DE MARCADORES MOLECULARES

2.3.1- Mapa Genômico

2.3.2- Identificação de Regiões que Influenciam em Características Quantitativas "QTL” $\quad 23$

$\begin{array}{ll}\text { Produção e Qualidade de Carne } & 24\end{array}$

$\begin{array}{ll}\text { Produção e Qualidade de Leite } & 26\end{array}$

$\begin{array}{ll}\text { Fertilidade } & 28\end{array}$

Doenças Hereditárias $\quad 29$

Resistência à Doenças Infecciosas $\quad 30$

2.3.3- Seleção Assistida por Marcadores Genéticos "MAS” $\quad 32$

2.3.4-Estudos Taxomômicos de Populacionais $\quad 35$

$\begin{array}{ll}\text { 2.3.5- Teste de Paternidade } & 38\end{array}$

3- MATERIAL E MÉTODOS 42

$\begin{array}{ll}\text { 3.1-MATERIAL } & 42\end{array}$

$\begin{array}{ll}\text { 3.1.1- Tampões } & 42\end{array}$

3.1.2- Soluções $\quad 44$

3.2-MÉTODOS $\quad 47$

3.2.1- Obtenção das Amostras 47

3.2.2- Coleta de Sangue $\quad 47$

3.2.3- Extração e Quantificação de DNA $\quad 47$

Método Desenvolvido por Innis et al. (1989) 48

Método Rápido de Extração e Purificação com Sal 48

3.2.4- Reação de Amplificação dos Marcadores RFLP 49

Hormônio do Crescimento

Kapa-Caseína $\quad 51$

$\beta$-Lactoglobulina $\quad 52$

3.2.5-Digestão das Amostras $\quad 52$ 
3.2.6- Eletroforese

3.2.7- Visualização dos Fragmentos de DNA

3.2.8- Marcação dos Iniciadores

3.2.9- Marcação Radioativa do Padrão de Peso Molecular

3.2.10-Reação de Amplificação dos Marcadores Microssatélites

INRA-006

BM-1224

IGF I

3.2.11- Visualização dos Microssatélites

Eletroforese

Gel de Sequênciamento

Coloração por Prata

Autoradiografia

3.3.1- Caracterização da Raça Nelore

Estimação do Peso Molecular

Frequência Gênica e Genotípica para RFLP

Frequência Gênica e Genotípica para Microssatélites

Conteúdo de Polimorfismo Informativo (PIC)

65

Heterozigosidade Intraloco (HET) e Heterozigosidade Média (HETM)

66

Diversidade Gênica Intraloco (DG) e Diversidade Gênica Média

Equilíbrio de Hardy-Weinberg (EHW) 
4- RESULTADOS E DISCUSSÃO $\quad 70$

4.1-CARACTERIZAÇÃO DA RAÇA NELORE $\quad 70$

4.1.1- Determinação dos Genótipos $\quad 70$

$\begin{array}{ll}\text { Kapa-Caseína } & 70\end{array}$

Hormônio do Crescimento $\quad 72$

$\begin{array}{ll}\beta \text {-Lactoglobulina } & 74\end{array}$

$\begin{array}{ll}\text { INRA-006 } & 76\end{array}$

$\begin{array}{ll}\text { CSFM-50 } & 76\end{array}$

$\begin{array}{ll}\text { BM-1224 } & 79\end{array}$

$\begin{array}{ll}\text { IGF I } & 79\end{array}$

4.1.2- Frequência Gênica para RFLP $\quad 82$

4.1.3- Frequência Gênica para Microssatélites $\quad, 83$

4.2- PROBABILIDADE DE EXCLUSÃO

$\begin{array}{ll}\text { 4.3- TESTE DE PATERNIDADE } & 88\end{array}$

4.3.1- Famílias Estudadas no Teste de Paternidade 90

5- CONCLUSÕES 95

REFERÊNCIAS BIBLIOGRÁFICAS 97 


\section{LISTA DE TABELAS}

Tabela 1. Peso médio da raça Nelore em CDP-Controle de Desenvolvimento Ponderal

Tabela 2. Cronologia das grandes descobertas na história da genética 09

Tabela 3. Relação entre período de exposição e contagem por segundo (CPS)

Tabela 4. Frequências gênicas observadas (freq) e seus respectivos erros padrão (ep), heterozigose (Het), diversidade gênica (Div) e conteúdo de polimorfismo informativo (PIC) para os marcadores RFLP Kapa-caseína (Kpcs), $\beta$-lactoglobulina ( $\beta$-lact) e Hormônio do Crescimento (GH) e teste $\chi^{2}$ para Equilibrio de Hardy-Weinberg (EHW)

Tabela 5. Frequências gênicas observadas (freq) e seus respectivos erros padrão (ep), heterozigose (Het), diversidade gênica (Div) e conteúdo de polimorfismo informativo (PIC) para o marcador microssatélite IGF I e teste $\chi^{2}$ para Equilíbrio de Hardy-Weingerg (EHW)

Tabela 6. Frequências gênicas observadas (freq) e seus respectivos erros padrão (ep), heterozigose (Het), diversidade gênica (Div) e conteúdo de polimorfismo informativo (PIC) para o marcador microssatélite BM- $1224 \mathrm{e}$ teste $\chi^{2}$ para Equilibrio de Hardy-Weinberg (EHW)

Tabela 7. Frequências gênicas observadas (freq) e seus respectivos erros padrão (ep), heterozigose (Het), diversidade gênica (Div) e conteúdo de polimorfismo informativo (PIC) para o marcador microssatélite CSFM- $50 \mathrm{e}$ teste $\chi^{2}$ para Equilíbrio de Hardy-Weinberg (EHW) 
Tabela 8. Frequências gênicas observadas (freq) e seus respectivos erros padrão (ep), heterozigose (Het), diversidade gênica (Div) e conteúdo de polimorfismo informativo (PIC) para o marcador microssatélite INRA-006 e teste $\chi^{2}$ para Equilíbrio de Hardy-Weinberg (EHW)

Tabela 9. Probabilidade de exclusão (PE) para cada marcador genético empregado e probabilidade de exclusão combinada (PEC) para todos os marcadores

Tabela 10. Genótipos dos animais participantes do teste de paternidade

Tabela 11. Proporção de touros excluídos de paternidade considerando os genótipos da vaca e da progênie e frequências gênicas na população e probabilidade de paternidade do touro considerado (PP) 


\section{LISTA DE FIGURAS}

Figura 1. Fragmento amplificado e sítios de restrição para a enzima Hinf I no alelo 1 de Kapa-caseína

Figura 2. Fragmento amplificado e sítios de restrição para a enzima Hinf I no alelo 2 de Kapa-caseína

Figura 3. Genótipos para Kappa-caseína, $M=$ Marcador de peso molecular ( $\phi x)$ e ND = amostra não digerida

Figura 4. Fragmento amplificado do alelo 1 do Hormônio de Crescimento

Figura 5. Fragmento amplificado e sítios de restrição para a enzima $A l u$ I no alelo 2 do Hormônio do Crescimento

Figura 6. Genótipos para Hormônio do Crescimento, $\mathrm{M}=$ Marcador de peso molecular $(\phi x)$ e ND = amostra não digerida

Figura 7. Fragmento amplificado e sítio de restrição para a enzima Hae III no alelo 1 da $\beta$ - Lactoglobulina

Figura 8. Fragmento amplificado e sítios de restrição para a enzima Hae III no alelo 2 da $\beta$ - Lactoglobulina

Figura 9. Genótipos para Beta-Lactoglobulina, $\mathbf{M}=$ marcador de peso molecular $(\phi x)$ e $\mathrm{ND}=$ amostra não digerida

Figura 10. Fragmento amplificado contendo a região microssatélite INRA- 006

Figura 11. Fragmento amplificado contendo a região microssatélite CSFM- 50

Figura 12. Genótipos para o microssatélite INRA-006, $M=$ marcador de peo molecular (10pb ladder) 
Figura 13. Genótipos para - o microssatélite CSFM-50: $M=$ marcador de peso molecular (10pb ladder)

Figura 14. Fragmento amplificado contendo a região microssatélite BM- 122479

Figura 15. Fragmento amplificado contendo a região microssatélite IGF I- 006

Figura 16. Genótipos para o microssatélite BM-1224: $M=$ marcador de peo molecular (10pb ladder)

Figura 17. Genótipos para o microssatélite IGF-I, M= marcador de peo molecular (10pb Ladder)

Figura 18. Famílias participantes do teste de paternidade 


\section{RESUMO}

O presente trabalho tem por objetivo estimar as freqüências gênicas para os marcadores genéticos RFLP kapa-caseína, $\beta$-lactoglobulina e hormônio do crescimento e os microssatélites IGF I, INRA-006, CSFM-50 e BM-1224 na raça Nelore e desenvolver um teste de paternidade.

As freqüências gênicas foram estimadas em um total de 63 animais da raça Nelore, não aparentados em primeiro grau, participantes da "PGP- Prova de Ganho de Peso", de 1995 do IZ de Sertãozinho. O Teste de Paternidade foi aplicado a 13 famílias obtidas aleatoriamente da amostra.

As freqüências gênicas obtidas para os RFLP foram, 0,913 e 0,087 para os alelo A e B da Kapa-caseína respectivamente, 0,405 e 0,595 para os alelos A e B da $\beta$ lactoglobulina respectivamente e freqüência 1,0 para o alelo A (leucina) do Hormônio do Crescimento. As freqüências encontradas para os microssatélites foram: IGF I, 2 alelos com 0,262 e 0,738; CSFM-50, 5 alelos com 0,016, 0,270, 0,246, 0,151 e 0,317; BM-1224, 7 alelos com 0,008, $0,048,0,460,0,278,0,119,0,079$ e 0,008 e INRA-006, 7 alelos com 0,150,0,008, 0,016, 0,191, $0,426,0,087$ e 0,119 .

A probabilidade de exclusão (PE) estimada para os marcadores Kapacaseína, $\beta$-lactoglobulina, Hormônio do Crescimento, IGF I, CSFM-50, BM-1224 e INRA-006 foi respectivamente, $0,0731,0,1759,0,0,1560,0,5077,0.4406$ e 0,5210 . A probabilidade de exclusão combinada (PEC) para todos os marcadores alcançou 0,9089.

Os resultados do Teste de Paternidade acusaram erro de identificação em duas das 13 famílias, ou seja, aproximadamente $15 \%$ da amostra. A paternidade foi negada para três sistemas genéticos (CSFM-50, BM-1224 e INRA-006) em uma das famílias e em um (BM-1224) sistema para a outra. Os resultados do teste de paternidade apresentaram probabilidade de paternidade variando entre 0,6115 e 0,9987 , com média 0,8814 . 


\section{SUMMARY}

This study was conducted to determin the gene frequency of the RFLP (Kappa-Casein, $\beta$-Lactoglobulin and Growth Hormone) and microsatellites (IGF I, INRA-006, CSFM50 and BM-1224) as genetic markers and the development of a Paternity Test in the Nelore breed.

The genes frequencies were estimated on 63 not close related Nelore animals that participated on the Sertãozinho-IZ "Feedlot Test of Performance" in 1995. The Paternity Test was applied to 13 random families.

The results of the RFLP genes frequencies were 0,913 and 0,087 on the Kappa-casein A and B alleles respectively; 0,405 and 0595 on the $\beta$-Lactoglobulin A and B alleles respectively, and 1,0 to the Growth Hormone (leucine) A allele. The microsatellites results were: IGF I, 2 alleles with 0,262 and 0,738; CSFM-50, 5 alleles with 0,016, 0,270, 0,246, 0,151 and 0,317; BM1224, 7 alleles with $0,008,0,048,0,460,0,278,0,119,0,079$ and 0,008, and INRA-006 7 alleles with, $0,150,0,008,0,016,0,191,0,426,0,087$ and 0,119 .

The Exclusion Probability estimated for the Kappa-casein, $\beta$ Lactoglobulin, Growth Hormone, IGF I, CSFM-50, BM-1224 and INRA-006 genetics markers was $0,0731,0,1759,0,0,0,1560,0,5077,0,4406$ and 0,5210 respectively, and the Combined Exclusion Probability for all markers was around 0,9089 .

The Paternity Test results showed misidentification in two of the 13 families, that means $15 \%$ of the sample. Misidentification were verified in three genetics systems (CSFM-50, BM-1224 and INRA-006) in one of the excluded families and in one (BM-1224) for the other. The Paternity Test results presented paternity probability in a range of 0,6115 and 0,9978 , with average of 0,8814 . 


\section{1) INTRODUÇÃO}

O melhoramento genético da raça Nelore vem sendo alcançado pela seleção de indivíduos que possuam um valor genético superior para características de crescimento, circunferência escrotal e avaliação subjetiva de musculosidade. Os animais selecionados são utilizados como reprodutores, alterando a constituição genética do rebanho, de modo a obter um incremento na produtividade.

Dentre as metodologias estatísticas disponíveis para a predição do mérito genético dos animais o "BLUP- Melhor Preditor Linear não Tendencioso" tem o emprego bastante difundido. A obtenção do valor genético através do BLUP é realizada utilizando dados de desempenho de animais aparentados. Portanto erros de identificação de paternidade são prejudiciais, reduzindo o ganho genético anual da população.

As relações de parentesco entre indivíduos podem ser verificadas empregando diversas categorias de marcadores genéticos. Esta verificação se convencionou chamar de teste de paternidade. Inicialmente marcadores morfológicos,

grupos sangüíneos, polimorfismos bioquímicos e complexo principal de histocompatibilidade (MHC) foram utilizados com este propósito. Entretanto, estas categorias de marcadores nem sempre fornecem resultados conclusivos, e devido ao grande número de sistemas genéticos necessários para um resultado adequado o custo do teste de paternidade limita o seu uso.

Os recentes avanços na área da biologia molecular, como por exemplo o desenvolvimento da reação em cadeia da polimerase (PCR) vem contribuindo significativamente para solucionar estas limitações, gerando novos sistemas genéticos conhecidos por marcadores moleculares.

Os marcadores moleculares que podem ser destacados com o propósito de teste de paternidade são: RFLP, impressão digital do DNA (DNAfingerprinting) e principalmente os microssatélites loco específico. Os microssatélites loco específico são, geralmente, altamente polimórficos, mesmo em populą̧ões endogâmicas, apresentando a vantagem de serem codominantes, bastante freqüêntes, bem distribuídos e 
facilmente obtidos por PCR. Estas características contribuem para facilitar a determinação da origem dos alelos paternais.

O teste de paternidade pode ser efetuado somente em animais pertencentes a populações caracterizadas para os sistemas genéticos que se pretende utilizar. Isto por que a probabilidade de paternidade é dependente da freqüência gênica dos alelos herdados do pai.

No presente trabalho serão estimadas as freqüências gênicas

para os marcadores genéticos RFLP kapa-caseína, $\beta$-lactoglobulina e hormônio do crescimento e os microssatélites IGF I, INRA-006, CSFM-50 e BM-1224 na raça Nelore com o objetivo de desenvolver um teste de paternidade. 


\section{2- REVISÃO DE LITERATURA}

\section{1-A RAÇA NELORE}

\subsection{1- Nomenclatura e Taxonomia}

Os bovinos são encontrados em praticamente todos os países do mundo e, estima-se que existam mais de 1,2 bilhões de animais de pelo menos 780 raças. A evolução da cultura humana tem sido influenciada pelos bovinos, representando importante fonte de alimento e trabalho (Loftus et al., 1994a, b). Pertencem ao gênero Bos, tribo Bovini, família Bovidae, e ordem Artiodactyla. Além do gênero Bos, a tribo Bovini possui os gêneros Bison (Bisão), Bubalus (Búfalo asiático) e Syncerus (Búfalo americano) (Nowak \& Paradiso, 1983; Simpson, 1984).

A nomenclatura clássica de Linnean distingue duas espécies do gênero Bos, o Bos taurus e Bos indicus. O grupo Bos taurus engloba as raças européias e africanas, sem cupim e Bos indicus as indianas e africanas, com cupim (Del Lama, 1991). Esta classificação é suportada na alta diversidade genética estimada a partir de polimorfismos protéicos (Manwell \& Baker, 1980) e polimorfismo do cromossomo Y, geralmente submetacêntrico em taurinos e acrocêntrico em zebuínos (Kieffer \& Cartwrigth, 1968).

Entretanto, esta classificação tem gerado muitas controvérsias, tanto ao nível de tribo, quanto de sub-gênero. Diversos autores propuseram reagrupar os gêneros Bos e Bison em um único gênero Bos, baseados na capacidade de serem gerados híbridos interespecíficos entre Bos e Bison, na anatomia, no DNA mitocondrial, no DNA ribossomal e análise de seqüências de DNA repetitivo (Modi et al. 1996).

Por outro lado, a classificação das raças européias e indianas como espécies diferentes parece inadequada, devido à completa interfertilidade e ao fato de não existir isolamento geográfico, como sugerem alguns autores, que classificam estes grupos como subgrupos 
da espécie Bos primigenius, Bos primigenius fd indicus e Bos primigenius fd taurus (Epstein \& Mason, 1984).

\subsection{2- Origem e Domesticação}

A domesticação de algumas espécies animais, em especial os bovinos, deve ter ocorrido há aproximadamente 9.000 anos, de acordo com achados arqueológicos e estudos isoenzimáticos (Epstein, 1971; Manwell \& Backer, 1980; Graml et al, 1986).

Diversos autores acreditam em uma origem monofilética, em que todas as raças domesticadas de bovinos, exceto o gado de Bali, descendem da extinta espécie bovina selvagem Bos primigenius, domesticada a 8.000-10.000 anos (Epstein, 1971; Grigson, 1980; Epstein \& Mason, 1984). Entretanto, a origem polifilética do gado doméstico vem sendo proposta em alguns estudos, indicando domesticação independente para os grupos bovinos taurinos e zebuínos (Naik, 1978; Grigson, 1980; Loftus et al., 1994 a, b).

O centro de dispersão do Bos primigenius foi a Ásia (Epstein \& Mason, 1984), de onde migrou para a Europa e África, durante o Pleistoceno. Esta ampla distribuição geográfica permitiu a sua diferenciação em três subespécies, o $B$. primigenius namadicus, asiático, o B.primigenius primigenius, europeu e o B. primigenius opisthonomus, norteafricano. O B. primigenius namadicus, subespécie selvagem que deu origem ao $B$. primigenius indicus, ocorreu durante todo o domínio da civilização Neolítica na Ásia (Del Lama, 1991).

Para se estimar a distância genética entre as raças taurinas e indianas. foi utilizada análise da seqüência de DNA mitocondrial. As raças estudadas formaram dois grupos distintos, um indiano e outro reunindo as raças européias e africanas. A divergência estimada entre zebuínos e taurinos ocorreu entre 575.000 e 1.150 .000 anos, bem acima dos 10.000 anos postulado pela hipótese de domesticação única (Loftus et al., 1994 a, b). 
Medjugorac et al. (1994) sugerem movimentos em larga escala, de populações de gado doméstico migrando conjuntamente com humanos da Ásia para a Europa, através dos Balcãs como explicação para as distâncias genéticas entre 14 raças de gado calculadas através de 86 locos de grupos sangüíneos, proteínas do sangue e do leite. Esta migração ocorreu no período Neolítico, há aproximadamente 9.000 anos, com a ocorrência de acasalamentos entre gado doméstico e selvagem.

\subsection{3- Introdução do Nelore no Brasil}

Os primeiros animais bovinos a desembarcarem no Brasil foram trazidos de Portugal por Martim Afonso de Souza e se espalharam pelo Brasil para serem utilizadas como tração animal. A introdução de gado zebuíno no Brasil objetivou melhorar a adaptação e rusticidade através de cruzamentos com os bovino existentes e ocorreu em três fases (Santiago, 1960; Del Lama, 1991).

A primeira etapa ocorreu durante a colonização, até o final do século XIX, com entradas ocasionais, de poucos animais, na Bahia. Estes foram acasalados com o gado existente, produzindo um gado mestiço que despertou a atenção de criadores. Após esta fase, iniciouse o grande ciclo das importações, sendo os fluminenses os precursores deste movimento. Ainda no século XIX, os mineiros passaram a adquirir animais dos plantéis do Rio de Janeiro e da Índia, formando um grande número de criações. No final deste período o zebu podia ser encontrado nos Estados do Rio de Janeiro, Minas Gerais e Bahia (Santiago, 1960).

A crise da peste bovina levou o governo brasileiro a proibir as importações em 1921. A partir desta data, somente 5 importações foram autorizadas, entretanto diversos animais continuaram a ser introduzidos no Brasil através de entradas ilegais de sêmen, provenientes da Índia, configurando assim a terceira fase (Del Lama, 1991). 
O Nelore foi introduzido, oficialmente, por Manuel Uberlhart Lengruber em 1880, como animal de zoológico. Entretanto, Santos (1991) afirma que diversas entradas ocorreram sem o conhecimento da alfândega.

\subsection{4- Aspectos Gerais da Raça Nelore}

A raça Nelore foi formada a partir do Ongole, gado grande, dócil, pelagem branca ou cinza clara, chifres curtos e face em forma de ataúde, proveniente do sul da Índia, mas recebeu alguma contribuição de gado Misore, com pelagem cinza a preto, chifres alongados e pontiagudos (Santiago 1960; Del Lama, 1991). O Nelore apresenta a combinação destes dois tipos raciais, com predominância do Ongole, apresentando caracteristicas adequadas à produção de carne (Santiago, 1985).

A padrão racial do Nelore é determinado pela $\mathrm{ABCZ}$ - Associação Brasileira dos Criadores de Zebu (BRASIL, 1994). Para ser registrado, o animal deve apresentar, entre outras características, bom desenvolvimento, ossatura forte, musculatura compacta e temperamento dócil e ativo. A cabeça deve possuir comprimento e largura médios, vista frontal em forma de ataúde, perfil subconvexo, orelhas curtas em ponta de lança, chifres curtos e firmes ou sem chifre na variedade mocha. Os pelos são curtos e finos de coloração branca e cinza e pele com pigmentação escura.

O Nelore vem sendo selecionado quase exclusivamente para produção de carne, representando a principal raça zebuína utilizada para este propósito, desde a década de sessenta (Santos, 1995). O registro dos animais começou a ser efetuado em 1938 e o livro de registros teve o seu fechamento em 1971. Até o ano de 1996, 3.395.804 animais Nelore haviam sido registrados, representando $72,21 \%$ do total do registro geral de nascimento (RGN), e 1.534 .774 animais haviam recebido o RGD- registro geral definitivo, ou seja, $66,92 \%$ do total. 
A média de peso de animais registrados da raça Nelore, participantes do programa de controle de desenvolvimento ponderal promovido pela $\mathrm{ABCZ}$ está apresentada na Tabela 1.

Tabela 1. Peso médio da raça Nelore em CDP- Controle de Desenvolvimento Ponderal da ABCZ.

\begin{tabular}{|c|c|c|c|c|c|c|c|c|c|c|}
\hline \multirow{3}{*}{ Sexo } & \multirow{3}{*}{$\begin{array}{l}\text { Peso } \\
\text { ao } \\
\text { Nascer }\end{array}$} & \multicolumn{9}{|c|}{ Idades Padrão (Dias) Regime Alimentar } \\
\hline & & \multicolumn{3}{|c|}{205} & \multicolumn{3}{|c|}{365} & \multicolumn{3}{|c|}{550} \\
\hline & & I & II & III & I & $\Pi$ & III & I & II & III \\
\hline M & 30 & 162 & 185 & 192 & 218 & 278 & 298 & 287 & 378 & 419 \\
\hline$F$ & 29 & 151 & 170 & 175 & 199 & 247 & 267 & 258 & 332 & 361 \\
\hline
\end{tabular}

$\mathrm{I}=$ animais à pasto, $\mathrm{II}=$ animais semi-estabulados, $\mathrm{III}=$ animais estabulados

Fonte: ABCZ- Associação dos Criados de Zebu, Uberaba/MG, 1994.

\subsection{5- Situação Atual}

A raça Nelore possui diversos criadores, empresas e instituições de pesquisa realizando programas de melhoramento genético, alguns dos quais foram apresentados no I Simpósio Nacional de Melhoramento Animal (1996) como por exemplo: DEPARTAMENTO DE GENÉTICA FMRP-USP (Lôbo, et al., 1996), PROMEBO- ANC (Campos, 1996), PAINT-Lagoa da Serra (Dias, 1996) e PROZEBU-ABCZ (Josahkian, 1996).

Estes programas de melhoramento genético utilizam, na maioria, a metodologia dos modelos mistos para a estimação do valor genético dos animais, em termos de Diferença Esperada Na Progênie-DEP para características relacionadas ao desenvolvimento ponderal, 
circunferência escrotal e avaliação de musculosidade e precocidade (Campos, 1996; Silva, 1996; Pötter, 1996; Purgly, 1996).

Além do melhoramento de Nelore puro, "raças sintéticas", como por exemplo o Brangus- Projeto Natura, Braford- Delta-G, Canchim, entre outras vem sendo desenvolvidas envolvendo criadores, empresas e instituições de pesquisa, utilizando o Nelore como raça Zebuína. A busca da heterozigosidade, almejando um incremento na produção devido a heterose, está bastante difundido entre os produtores e novamente o Nelore está sendo bastante aproveitado em cruzamentos com raças de origem européia, como o Charolês, Chianina e Fleckvieh (Euclides, Filho, 1996).

\section{2- DESENVOLVIMENTO DA GENÉTICA}

\subsection{1- Grandes Descobertas na História da Genética}

Emery e Malcon (1995) publicaram uma relação, apresentada na Tabela 2, com as principais descobertas responsáveis pelo desenvolvimento da tecnologia do DNA recombinante. Gregor Mendel é considerado o "Pai da Genética" por ter formulado em 1866 as leis da herança, com base se em seus experimentos com ervilhas. $\mathrm{O}$ termo entidade mendeliana é utilizada ao se referir a uma característica de herança simples, ou seja, determinada por um par de alelos. Estes alelos são transmitidos, um de cada progenitor à prole. Pouca importância foi dada aos experimentos de Mendel até o final do século XIX. 
Tabela 2. Cronologia das grandes descobertas na história da genética

\begin{tabular}{|c|c|}
\hline 1866- Gregor Mendel & Formulação das leis da herança \\
\hline 1902- Walter Sutton & Localização dos fatores hereditários nos cromossomos \\
\hline 1906- William Bateson & Descoberta do princípio de ligação genética \\
\hline 1908- Hardy-Weinberg & Primeiras estudos de genética de populações \\
\hline 1912- Thomas Morton & Conceito da disposição linear dos alelos no cromossomo \\
\hline 1944- Avery; McLeod e & Informações genéticas armazenadas em ácidos nucléico (DNA) e não \\
\hline McCarty & em proteínas \\
\hline 1953- Watson e Crick & Demonstração da estrutura molecular do DNA \\
\hline 1961- Jacob e Monod & Proposição do modelo "operon" \\
\hline 1965- Arber & Descoberta das enzimas de restrição \\
\hline 1966-Nirenberg; & \\
\hline Mathaaei e Leder & Estabelecimento do código genético \\
\hline 1970- Kelly e Smith & Descoberta das enzimas de restrição tipo II \\
\hline 1974- Grodzicker & $\begin{array}{l}\text { Primeira utilização dos polimorfismos de fragmentos por restrição } \\
\text { "RFLPs" em análise genética }\end{array}$ \\
\hline 1975- Southern & Desenvolvimento da técnica "Southern Bloting" \\
\hline 1980-Botstein & Construção de mapa de ligação empregando "RFLP" \\
\hline 1983-Mullis & Formulação da reação em cadeia da polimerase (PCR) \\
\hline 1985- Jeffreys & $\begin{array}{l}\text { Utilização de sonda multilocal para regiões minissatélites para gerar } \\
\text { padrão genético complexo }\end{array}$ \\
\hline 1988- Saiki & Utilização de Polimerase Termoestável \\
\hline $\begin{array}{l}\text { 1989- Tautz; Weber e } \\
\text { May }\end{array}$ & Emprego de PCR na detecção de microssatélite unilocal \\
\hline 1994-Bishop; Barendse & Publicação dos primeiros mapas genéticos de bovinos \\
\hline
\end{tabular}

Fonte: Emery \& Malcon (1996) modificado. 
Em 1902, Walter Sutton formulou a teoria de que as unidades de herança, como eram chamados os genes na época, estavam fisicamente localizados nos cromossomos. William Bateson em 1906, descobriu o conceito de ligação genética entre características localizadas em um mesmo cromossomo. Em 1912, Thomas Morgan apresentou o conceito da disposição linear dos genes em cada cromossomo.

A natureza química do gene começou a ser desvendado somente em 1944, com as descobertas de Oswald Avery, MacLeoad e McCarty. Estes autores estabeleceram que os genes são compostos de ácido nucléico, conhecido por ácido desoxirribonucléico- DNA e não por proteínas como se acreditava anteriormente. Watson e Crick, propuseram, em 1953, a estrutura dupla fita em espiral para o DNA. Cada fita seria uma cadeia de nucleotídeos, e cada nucleotídeo composto por uma base nitrogenada, uma molécula de açúcar e uma molécula de fosfato. Nirenberg, Nathaaei e Leder decifraram o código genético em 1966, estabelecendo a relação entre as combinações possíveis de trinca de nucleotídeos, conhecida por "codon" e os vinte aminoácidos existentes.

Estas descobertas contribuíram para o progresso da genética, que por sua vez influenciou outras disciplinas como a biologia, a citologia e em especial o melhoramento genético das diferentes espécies cultivadas. O desenvolvimento das técnicas empregadas no estudo do DNA, como "Southern Bloting" e "PCR- polimerase chain reaction", esta contribuindo para se aprofundar o conhecimento da estrutura e regulação da expressão do código genético.

Em 1996, o Mapa Genômico de humanos apresentava aproximadamente 1.000 marcadores genéticos polimórficos distribuídos ao longo do genoma e mais de 16.000 genes mapeados como resultado do esforço conjunto de diversos países. (Schuler et al. 1996). Os bovinos possuem três mapas genéticos publicados (Fries et al., 1993; Bishop et al., 1994; Barendse et al., 1994) e 877 locos com informações relacionadas ao seu mapeamento (Eggen \& Fries, 1995).

As informações relacionadas às seqüências nucleotídicas do DNA, de aminoácidos das proteínas correspondentes, características estruturais das proteínas, assim como 
informações relacionadas à sua atividade biológica para as diferentes espécies (Homo sapiens, Mus musculus, Bos taurus, etc... ) provenientes de diferentes bancos de dados (por exemplo: Genethon e EMBL Data Library) estão depositadas no GenBank e podem ser acessadas via Internet (Benson et al., 1996).

Um mapa genético saturado é pré-requisito para a identificação de regiões cromossômicas que interferem em características de interesse econômico (Beckmann \& Soller, 1990). Estes estudos de associação entre características de importância econômico e marcadores genéticos fornecem subsídios para a implementação das metodologias de avaliação genética empregadas na seleção de reprodutores (Georges et al., 1995). O conhecimento de características genéticas desejáveis, através de marcadores genéticos, permitiria o seu uso em programas de seleção assistida por marcadores (Soller \& Beckmann, 1983). Os marcadores deverão ser particularmente importantes em características de dificil mensuração ou que não podem ser diretamente mensuradas (resistência a doenças, características de carcaça e produção de leite em touros), de baixa herdabilidade (fertilidade), ou que apresentam correlações genéticas negativas (produção de leite e concentração de gordura no leite) (Schwerin et al., 1995).

\subsection{2- Marcadores Genéticos}

A domesticação dos animais permitiu ao ser humano exercer a seleção artificial para características desejáveis e alterar, mesmo que inconscientemente, a constituição genotípica destas populações (Santos, 1995). O conhecimento de que estas características fenotípicas são herdáveis, levou o homem a controlar os acasalamentos nestas espécies, selecionando os reprodutores (Reed, 1984).

A capacidade de revelar a composição genética de um indivíduo, a partir de seu fenótipo, define o que se convencionou chamar de marcador genético (Cavalli-Sforza \& 
Edwards, 1967). O termo marcador molecular foi definido por Ferreira e Grattapaglia (1995) como todo e qualquer fenótipo molecular oriundo de um gene expresso ou de um segmento específico do DNA (correspondente a regiões expressas ou não do genoma).

O uso de marcadores genéticos no auxílio da seleção dos reprodutores, estratégia conhecida por "MAS- seleção assistida por marcadores", vem sendo proposta por diversos autores desde o início do século XX (Sax, 1923; Schmutz et al., 1995).

\section{Marcadores Morfológicos}

Os marcadores empregados para estudos de genética e melhoramento eram, até a década de sessenta, predominantemente, marcadores morfológicos. Estes contribuíram consideravelmente para o desenvolvimento teórico da análise de ligação e construção das versões iniciais de mapas de ligação (Ferreira \& Grattapaglia, 1995).

Os primeiros marcadores utilizados para esta finalidade foram a ausência de asas em Drosophila e a de pelos em camundongos. Entretanto, estas características são resultantes de mutações gênicas pouco freqüêntes e que normalmente comprometem a adaptação dos indivíduos (Tanksley, 1993)

Além disto, o pequeno número de marcadores diferentes em uma mesma linhagem e relações de dominância entre os diferentes alelos reduzem significativamente a probabilidade de serem encontradas associações positivas com características de importância econômica (Del Lama, 1991; Ferreira \& Grattapaglia, 1995). 


\section{Marcadores Bioquímicos}

Os marcadores bioquímicos compreendem os polimorfismos de proteínas plasmáticas, por exemplo albumina, esterase e 6-fosfogluconato desidrogenase (Regitano, 1991) e proteínas com atividade enzimática, conhecidos por isoenzimas.

Os marcadores isoenzimáticos são moléculas distintas de mesma afinidade enzimática, podendo ser determinadas por eletroforese e deteç̧ão histoquímica (Market \& Moller, 1959). A análise isoenzimática foi disseminada na década de sessenta, sendo desde então, aplicada a diversos organismos (Lush, 1966; Baker \& Manwell, 1983).

Esta categoria de marcador genético foi utilizada para identificação de animais, teste de parentesco, estudo da estrutura populacional e racial, mapeamento genético e associação com características de importância econômica (Baker \& Manwell, 1983).

As principais limitações ao uso destes marcadores genéticos são o número total de locos que podem ser acessados no genoma, o baixo polimorfismo por loco, modificações pós-tradução produzindo formas múltiplas do produto de um único gene e dificuldade de interpretação de zimogramas de isoenzimas de diferentes locos com mobilidade eletroforética idêntica (Ferreira \& Grattapaglia, 1995).

\section{Antígenos Eritrocitários}

Os grupos sangǘneos, ou antígenos eritrocitários, foram descritos, primeiramente, em humanos por Landsteiner (1900) no final do século passado e em cabras na mesma época por Erlich \& Morgenroth (1900). A determinação do grupo sangüíneo é realizada por reações sorológicas, empregando-se anticorpos específicos para os diferentes antígenos eritrocitários, e a presença do antígeno é detectada a partir da aglutinação das hemácias, ou pela hemólise resultante da adição de soro complemento à mistura hemácia-anticorpo (Del Lama, 1991). 
Estes marcadores são geneticamente determinados e possuem herança mendeliana simples, apresentando, no entanto, relações de dominância entre os seus alelos. Os métodos sorológicos de deteç̧ão e aspectos genéticos dos sistemas de grupamentos sangüíneos foram revisados por Bell (1983).

\subsection{3- Marcadores Moleculares}

\section{RFLP}

Os marcadores de DNA, conhecidos por "RFLP- Restriction Fragment Length Polimorphysm" foram inicialmente aplicados na deteç̧ão de mutações no material genético de vírus e posteriormente, em outros organismos (Botstein, et al., 1980).

O termo RFLP pode ser traduzido como polimorfismo no comprimento de fragmentos obtidos por restrição da fita de DNA. Esta fragmentação é obtida através do uso de enzimas de restrição tipo II (Kelly e Smith, 1970). Estas enzimas possuem sítios específicos de clivagem, de modo que um rearranjo da fita de DNA, por inserção, deleção ou mutações pontuais pode eliminar ou criar um novo sítio de restrição, modificando o tamanho dos fragmentos obtidos pela clivagem do DNA (Ferreira \& Grattapaglia, 1995).

A deteç̧ão dos fragmentos resultantes da digestão do DNA pode ser visualizada através da sua transferência e imobilização para uma membrana de nylon, técnica conhecida por "Sourthern Blot" (Sourthern, 1975) e hibridização com sondas de DNA homólogas ao DNA imobilizado.

Uma vez que os RFLPs possuem ampla distribuição pelo genoma e codominância, esta categoria de marcadores genéticos abriu perspectiva relevante no estudo do genoma, contribuindo imensamente para o desenvolvimento dos mapas genômicos (Botstein et al., 1980), e renovando o 
interesse no uso de marcadores genéticos em estudos de localização de QTL e, conseqüentemente, Seleção Assistida por Marcadores-"MAS" (Weller et al., 1990; Rocha et al., 1992). Entretanto, os RFLPs são dialélicos, fornecendo pouca heterozigosidade e Conteúdo de Polimorfismo Informativo (PIC).

\section{Minissatélites}

A descrição de regiões hipervariáveis do DNA em humanos por Jeffreys et al. (1985a) e por Georges et al. (1988) em outras espécies domésticas, abriu outro capítulo no desenvolvimento de marcadores moleculares. Estas regiões, conhecidas por "VNTRVariable Number of Tandem Repats", "Hypervariable Loci" ou "Minisatellites ", são constituídas de seqüências núcleo "Core Sequence", de 15 a 100 pb, que possuem um número variável de repetições idênticas adjacentes (Jeffreys et al., 1985a; Ferreira \& Grattapaglia, 1995).

Estes marcadores são obtidos, assim como os RFLPs, através da clivagem de DNA genômico com enzimas de restrição específicas, eletroforese, imobilização dos fragmentos e hibridização com sondas complementares. Para minissatélites estas sondas são homólogas à seqüência núcleo (Ferreira \& Grattapaglia, 1995)

Esta abordagem multilocal, também conhecida por Impressão Digital Genética, ou "DNA-fingerprinting", mostra-se útil em estudos de diversidade genética, taxonomia, testes de parentesco, diagnóstico de paternidade, medicina forense, diagnóstico de doenças, introgressão genética e análise de ligação (Jeffreys et al., 1991; Nakamura et al., 1987; Ferreira \& Grattapaglia, 1995).

No entanto, a prevalência destas "VNTR" em regiões proterminais dos cromossomos (Royle et al., 1988) e a característica multilocal da impressão digital genética prejudicam a construção de mapas genéticos. Um tratamento unilocal foi proposto por Wong et al. 
(1986) e Nakamura et al. (1987), com utilidade somente nos casos onde se possui conhecimento prévio da seqüência de nucleotídeos.

\section{Marcadores Genéticos Obtidos por "PCR"}

A metodologia para amplificação de fragmentos de DNA, conhecida como Reação em Cadeia da Polimerase "PCR- Polimerase Chain Reaction", foi formulada em 1983 por Mullis e apresentada à comunidade científica em 1984 ( Erlich et al., 1988; Mullis, 1990).

Saiki et al. (1988) modificaram a reação substituindo o fragmento Klenow, extraido da enzima DNA polimerase I, por Taq DNA polimerase termoestável, purificada a partir da bactéria Thermus aquaticus. Esta alteração resolveu o problema de falta de estabilidade térmica do fragmento Klenow, melhorando bastante a praticidade e especificidade e rendimento da reação.

O "PCR" se tornou uma arma poderosa para estudos genéticomoleculares devido a facilidade, rapidez e sensibilidade, substituindo muitos métodos tradicionais de análise de polimorfismo. Entretanto, o uso desta técnica esta condicionado ao conhecimento prévio da seqüência de nucleotídeos (Ferreira \& Grattapaglia, 1995).

\section{RAPD}

Os marcadores RAPD foram desenvolvidos, independentemente, por dois grupos de pesquisadores nos Estados Unidos. Williams et al. (1990) patentearam a técnica com o nome "RAPD- Random Amplified Polymorphic DNA". Welsh \& McClelland (1990) propuseram a denominação "AP-PCR Arbitrarily Primed Polimerase Chain Reaction". O nome "DAF-DNA 
Amplification Fingerprinting" foi sugerido por Caetano-Anólles et al. (1991) devido ao complexo padrão de bandas obtidos nesta técnica.

Estes marcadores são obtidos através da amplificação de fragmentos específicos do DNA através da técnica "PCR". A reação de amplificação é realizada com iniciadores de reduzido número de nucleotídeos, aproximadamente 10 , e temperatura de anelamento abaixo do ideal, produzindo uma reação de baixa especificidade. Estas características permitem que o iniciador se anele em diversos locos, gerando múltiplas bandas (Williams et al., 1990; Welsh \& McClelland, 1990).

Os marcadores RAPD são de detecção bastante simples, requerendo somente amplificação do DNA e eletroforese, gerando marcas em regiões cromossômicas não acessiveis à "RFLP", entretanto, alguns locos do DNA produzem bandas homólogas, isto é, de migração similar em gel de eletroforese, apresentando também relações de dominância entre seus alelos, além disto, fragmentos podem ser gerados a partir de DNA nuclear ou citoplasmático (Ferreira \& Grattapaglia, 1995).

O uso destes marcadores se difundiu rapidamente e suas aplicações incluem obtenção de Impressões Digitais Genéticas em diferentes níveis filogenéticos, isto é, indivíduos, populações, espécies, ou ainda, gênero, família, etc; análise da estrutura e diversidade genética em populações naturais ou domésticas; estudos taxonômicos, teste de paternidade e construção de mapas de ligação e associação com regiões cromossômicas que interferem em características quantitativas "QTL" (Williams et al., 1990).

\section{Microssatélites}

Desde a descoberta das regiões repetitivas do DNA (Miesfeld et al., 1981; Hamada et al., 1982; Jeffreys et al.,1985a; Georges et al., 1988), uma grande quantidade de locos "VNTR", altamente polimórficos, vem sendo descritos em diversas espécies (Weber e May, 
1989; Litt \& Luty, 1989; Tautz, 1989; Fries et al., 1990; Steffen et al., 1993; Gúerin et al., 1994; Kemp et al., 1995; Zhang et al., 1995).

Os Microssatélites são pequenas seqüências não codificadoras, de 2 à 6 pares de base, com número variável de repetições (VNTR), normalmente menores do que 100 pb. Os

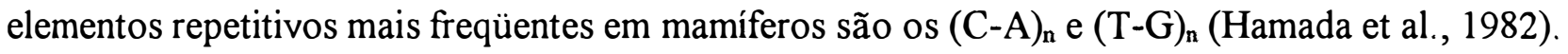

O polimorfismo de microssatélites pode ser visualizado a partir de amplificação de regiões "VNTR" por PCR, obtenção de bandas através de eletroforese em gel de poliacrilamida e marcação dos fragmentos com radiação. A diferença entre os alelos pode ser tão pequena quanto dois nucleotídeos, podendo ser analisados dois ou mais microssatélites simultaneamente (Weber \& May, 1989; Georges et al. 1990).

Estes marcadores apresentam, geralmente, alto nível de polimorfismo, ocorrendo com maior freqüência e, aparentemente, melhor distribuídos no genoma da maioria dos eucariotos do que os minissatélites (Hamada et al., 1982; Litt \& Luty, 1989; Tautz, 1989; Weber \& May, 1989; Fries et al., 1990).

A alta frequeência com que ocorrem nos eucariotos, o alto nível de polimorfismo, a distribuição ao longo do genoma, tanto cromossomos autossômicos quanto sexuais, codominância e a facilidade de deteç̧ão fizeram dos microssatélites os marcadores escolhidos para construção de mapas de ligação, representando uma linguagem universal de mapeamento (Fries, 1993; Bishop et al., 1994).

O polimorfismo encontrado em populą̧ões endogâmicas costuma ser relativamente pequeno (Cowan et al., 1990), mas o polimorfismo obtido nas raças bovinas parece ser suficiente para a construção de mapas de ligação (Soller, 1990).

Investigação comparativa permite adicionar ao mapa de ligação de bovinos informações referentes a locos microssatélites de espécies que possuem mapa mais desenvolvido, como de humanos e ratos, devido à conservação cromossômica existente entre diferentes genomas (Moore et al., 1991). 


\section{Polimorfismo de Conformação}

Os marcadores de polimorfismo de conformação são utilizados para a deteç̧ão de mutações do DNA. O método esta baseado na migração anormal de fragmentos de peso molecular similar, em decorrência de alterações na composição de nucleotídeos (Kirkpatrick et al., 1993; Kirkpatrick \& Hart, 1994; Liu \& Sommer, 1995)

O DNA possui a característica de se dobrar a cada nucleotídeo, formando uma dupla-hélice, sendo que a base nitrogenada do nucleotídeo determina o ângulo de inserção na fita de DNA. Vários aspectos da composição de bases nitrogenadas e comportamento conformacional da fita de DNA foram descritos por Crothers et al. (1990). Esta característica conformacional foi bastante estudada devido a suas implicações funcionais na transcrição, no empacotamento do DNA e acoplamento de proteínas (Kirkpatrick, et al., 1993).

Estes marcadores são obtidos a partir da amplificação de fragmentos de 150-450 pb e separação dos alelos através de eletroforese em condições especiais de temperatura. O DNA amplificado pode ser analisado, após desnaturação, na forma de fita simples "SSCP- Single Stranded Conformation Polimrphysm", ou na forma de fita dupla "DSCP- Double Stranded Conformation Polimorphysm" (Hart et al., 1993; Kirkpatrick, 1993; Kirkpatrick et al., 1993).

Os polimorfismos de conformação de fita simples de DNA são obtidos através da desnaturação do fragmento amplificado, resfriamento rápido para evitar o reanelamento e eletroforese não-desnaturante, na presença ou ausência de glicerol, e sob diferentes temperaturas como a $5^{\circ} \mathrm{C}, 10^{\circ} \mathrm{C}, 15^{\circ} \mathrm{C}$ ou temperatura ambiente e a sensibilidade pode variar com a região analisada (Orita et al., 1989).

Os "DSCP" são obtidos pela eletroforese do fragmento amplificado em gel de poliacrilamida não desnaturante, normalmente em diferentes temperaturas, apresentando alto conteúdo de polimorfismo informativo "PIC" (Kirkpatrick et al., 1993). 
Diversas variações de polimorfismo de conformação vem sendo desenvolvidas, como o "SSCP- single strand conformation polymorphism" após digestão, com endonucleases de restrição, de grandes fragmentos de DNA, gerando múltiplos fragmentos, o "ddFdideoxi fingerprinting" obtido através da amplificação pelo método de Sanger, utilizando somente um dos ddNTP, este método pode detectar $100 \%$ das mutações na seqüência de nucleotídeos e finalmente o método "REF- Restriction Endonuclease Fingerprinting", que consiste em digestões, separadas, com diversas enzimas de restrição e eletroforese simultânea em uma única linha do gel. O complexo padrão de bandas obtido permite acessar essencialmente $100 \%$ das mutações (Liu \& Sommer, 1995). Esta técnica pode ser bastante eficiente em estudos de paternidade, quando não se faz necessário um tratamento unilocal dos marcadores. 


\section{3- USO DE MARCADORES GENÉTICOS}

\subsection{1- Mapeamento Genômico}

O genoma bovino consiste de 30 pares cromossômicos homólogos, 29 pares autossômicos e 1 sexual, sendo que o macho é heterogamético XY e a fêmea homogamética $\mathrm{XX}$, com aproximadamente $3000 \mathrm{cM}$ no total. Por convenção, os cromossomos são agrupados em função da posição do centrômero como metacêntrico, submetacêntrico e acrocêntrico e numerados em função do tamanho. O braço pequeno do cromossomo é denominado " $p$ " e o longo "q". Através de coloração com o corante Ginsa, pode-se visualizar os cromossomos com um padrão de bandas característico, que também recebem uma numeração (Banda-G). Um determinado ponto em um cromossomo é denominado pelo número do cromossomo, o símbolo do braço e número da banda-G (Fries et al., 1993). Desta forma o gene do hormônio do crescimento está localizado por 19q17, o gene da $\beta$-lactoglobulina por 11 q28 e da kapa- caseína por $6 \mathrm{q} 26$.

Quando diferentes genes estão localizados no mesmo cromossomo diz-

se que estes locos estão ligados. $\mathrm{O}$ processo da permuta ou recombinação que ocorre durante a meiose na formação dos gametas é responsável pela troca de segmentos de DNA entre cromossomos homólogos. A frequência deste evento é proporcional a distância entre os locos. As distâncias são mensuradas como função da freqüência de recombinação na progênie e expressas em centiMorgan (cM). Um centiMorgam equivale a aproximadamente $10^{6}$ pares de base (Emery \& Malcon, 1995).

A aplicação de diferentes métodos de mapeamento gera dois mapas diferentes mas complementares, o fisico e genético. $O$ mapa genético é construído através da análise de segregação em famílias informativas (um parental é heterozigoto para os dois locos) empregando modelos estatísticos adequados (Weller et al., 1990), para se determinar a freqüência de recombinação gênica na progênie (Fries, 1993). O mapeamento genético pode ser feito sem análise de progênie através da análise de espermatozóides, avaliando a freqüência de recombinação diretamente nos gametas, o que pode ser de grande valia, especialmente em espécies que não podem ser criadas em grande número ou possuem intervalo entre gerações muito longo (Amhein et al., 1990). 
Um mapa genético completo e eficiente consiste de marcadores altamente polimórficos, distantes $40 \mathrm{cM}$ um do outro, para que qualquer loco esteja no máximo a 20 cM do marcador (Lander \& Botstein, 1989). Três marcadores por cromossomo seria um número inicial suficiente para cobrir todo o genoma (Fries et al., 1989). Os Microssatélites apresentam, geralmente, alto nível de polimorfismo, ocorrendo com maior freqüência, melhor distribuídos no genoma da maioria dos eucariontes do que os minissatélites, além da facilidade de detecção através de "PCR". Estas características fizeram dos microssatélites os marcadores escolhidos para construção de mapas de ligação (Litt \& Luty, 1989; Tautz, 1989; Weber \& May, 1989; Beckmann \& Soller, 1990; Luty et al. 1990).

O conteúdo de polimorfismo informativo, conhecido por "PIC" para um deterninado marcador, refere-se a parcela da progênie em que é possível determinar exatamente de qual progenitor os alelos são provenientes. O PIC é dependente no número de alelos detectáveis por loco e de freqüências semelhantes entre estes alelos. Este polimorfismo permite acompanhar a segregação dos alelos na progênie (Botstein et al., 1980).

O polimorfismo encontrado em populações endogâmicas costuma ser relativamente menor do que em populações não endogâmicas (Cowan et al.,1990), mas a variação obtida nas raças bovinas deve ser suficiente para o mapeamento (Soller, 1990; Georges \& Massey, 1991). Bishop et al. (1994) publicaram um mapa genético de bovinos com 306 marcadores genéticos, dos quais 290 microssatélites, cobrindo praticamente todo o genoma. Barendse et al. (1994) publicaram outro mapa de bovinos com mais de 200 locos descritos.

O mapeamento fisico em bovinos é construído, basicamente, a partir de investigação comparativa. Uma considerável conservação cromossômica é observada entre diferentes genomas de mamíferos, portanto, informações referentes a genes mapeados em humanos e ratos, que possuem um genoma melhor estudado podem ser adicionadas ao mapa bovino (Womack \& Moll, 1986).

Uma vez conhecidos os rearranjos cromossômicos que ocorreram durante a evolução dos mamíferos e os grupos sintênicos definidos, extrapolações podem ser feitas de um genoma para o outro (Womack \& Moll, 1986; Fries, 1993). Como exemplo da alta conservação existente entre humanos e bovinos podem ser citados os cromossomos humanos 9 e 12, quase completamente conservados em bovinos (Fries, 1993). 
Regiões cromossômicas homólogas, ou seja, segmentos de DNA que possuem os mesmos genes ligados em ambas as espécies, também conhecidos como grupos sintênicos podem ser identificadas através da produção de células somáticas híbridas interespecíficas, técnica conhecida por "hibridização de células somáticas" e análise dos genes e produtos gênicos das mesmas utilizando RFLP, diagnóstico por "PCR" e hibridização "in situ" (Fries et al., 1993). Alguns exemplos são: Threadgill \& Womack (1994) realizaram o mapeamento sintênico do braço curto do cromossomo 8 de humanos em bovinos através de hibridização "in situ" isotópica com ${ }^{32} \mathrm{P}$. Eggen et al. (1994) localizaram o grupo sintênico U2 no cromossomo 9q25 utilizando o microssatélite INRA144 através de hibridização "in situ" fluorescente (FISH).

\subsection{2- Identificação de Genes que Influenciam Características Quantitativas "QTL"}

O conhecimento das características moleculares da transcrição gênica, processamento "splicing" do RNA, controle da transcrição e pós-transcrição; identificação de fatores de crescimento peptídeos e outras moléculas relacionadas ao crescimento celular normal e anormal; entendimento dos mecanismos de segundos mensageiros, AMPc- adenosina monofosfatada cíclica, GMPc- Guanosina monofosfatada cíclica, do cálcio e Fosfatidilinusitol, contribuirão para expandir o entendimento da biologia celular, bioquímica e fisiologia relacionadas à produção animal (Young, 1987). Este conhecimento permitirá manipular os fluxos de energia e metabólitos para aumentar a eficiência de produção, através da utilização de seleção genética, cruzamentos, emprego de substâncias exógenas, manejo nutricional, entre outras.

O objetivo principal da aplicação de técnicas de genética molecular ao melhoramento animal, atualmente, consiste em identificar e clonar genes que interferem no metabolismo de características de importância econômica, de maneira a melhorar a compreensão do controle genético de características complexas como reprodução e crescimento. Os principais procedimentos utilizados com o propósito de mapeamento são o do gene candidato ou o baseado em mapa genético (Schwerin et al., 1995). 
O procedimento do gene candidato refere-se ao mapeamento fisico convencional de genes relacionados a proteínas-chave de vias metabólicas de importantes processos fisiológicos, gerando os marcadores tipo I, ou seja, polimorfismo determinante de variação fenotípica. No procedimento baseado em mapa genético, diversos marcadores moleculares polimórficos são empregados para localizar regiões cromossômicas, que interferem em características quantitativas, conhecidas por "QTL" (Quantitative Trait Locus), ou ainda "ETL" (Economic Traits Locus). Estes são chamados de marcadores tipo II, ou seja, polimoefismo em ligação com marcadores tipo I, sendo os microssatélites bastante importantes neste tipo de estudo (O'Brien, 1991). Diversos pesquisadores estão estudando a associação de marcadores tipo I e tipo II e características de importância, como produção de leite, carne, fertilidade, resistência a doenças e estresse

\section{Produção e Qualidade da Carne}

O desenvolvimento ponderal, a eficiência alimentar, maciez da carne, gordura marmorizada e de cobertura são algumas das principais características avaliadas nos reprodutores com pouco conhecimento de suas bases genéticas. Os avanços da Genética Molecular permitem estudar com maior profundidade os genes envolvidos nas principais vias metabólicas relacionadas ao crescimento animal e repartição de nutrientes para os diferentes tecidos (Schwerin et al., 1995). A seguir são descritos alguns casos de genes com efeito importante nestas características.

Os animais de dupla musculatura apresentam hipertrofia muscular, baixo conteúdo de gordura na carcaça e redução da taxa de conversão alimentar. Esta característica é determinada por um loco autossômico com herança parcialmente recessiva (Hanset \& Michaux, 1985). Uma banda de "DNA Fingerprinting" correlacionada com o fenótipo da hipertrofia foi identificada por Georges et al. (1990). Entretanto nenhum marcador de importância prática esta disponível.

O hormônio do crescimento, através do IGF I desempenha importante papel na regulação do crescimento (Schlee et al., 1994). O fator ativador da Pituitária necessário para secreção do GH é conhecido por PIT I. A somatostatina, por ser um potente inibidor do GH, também 
pode ser considerada um gene candidato (Thue \& Schmutz, 1994). Os genes K-caseína, $\beta$ lactoglobulina são expressos nos leite, podendo ser importantes na avaliação do potencial de produção de leite, expresso como habilidade materna em gado de corte. Desta forma, estes locos podem ser considerados candidatos para características de crescimento (Moody et al., 1996).

Beever et al. (1990) avaliaram associações entre os marcadores genéticos antígeno leucocitário bovino -A "BoLA-A", grupos sangüíneos $\mathrm{B}, \mathrm{C}$ e F, transferrina sérica e proteína carreadora de vitamina $\mathrm{D}$ e características de carcaça em familia de meio-irmãos $(n=146)$ na raça Aberdeen Angus. Os autores encontraram efeitos significativos entre grupo sangüíneo $\mathrm{B} e$ peso ajustado para 205 dias e aos 365 dias, ganho diário pré-desmama e espessura da camada de gordura. Efeito significativo entre Bola e área de olho de lombo. Os autores sugerem uma possível ligação entre estes sistemas e genes interferindo nestas características.

Rocha et al. (1992) estudaram o efeito dos genes hormônio do crescimento, hormônio paratireoidiano, prolactina, osteonectina e keratina, com genótipos determinados através de RFLP com as enzimas de restrição Taq I, Msp I, EcoRI, Msp I e Msp I respectivamente em características de desempenho e conformação em 677 animais puros e cruzados entre as raças Aberdeen Angus, Brahman, Hereford, Holandês e Jersey. Os resultados encontrados evidenciaram uma associação entre alelos $\mathrm{B}, \mathrm{C}$ e $\mathrm{D}$ do hormônio do crescimento e decréscimo do peso ao nascimento de 1,0 desvio padrão em gado Brahman, cruzados Angus-Brahman e BrahmanHereford e associações significativas entre hormônio paratireoidiano e peso a desmama e tamanho corporal. Os outros marcadores não apresentaram efeitos significativos nas características avaliadas. Os autores sugerem que este conhecimentos poderiam ser utilizados por criadores nos programas de seleção, mas para tanto, outros estudos deveriam ser conduzidos com um número maior de animais para validar os achados e evitar interações e confundimentos de diferentes fontes de variação.

Moody et al. (1996) estudaram possíveis associações entre polimorfismos dos genes K-caseína, $\beta$-lactoglobulina, hormônio do crescimento " $\mathrm{GH}$ ", receptor do GH e fator ativador de transcrição da pituitária "PIT I" estimados através de "PCR-RFLP" e fator semelhante à insulina "IGF I" e prolactina "PRL" avaliados através de microssatélites com características de crescimento e de habilidade materna em bovinos de três linhagens da raça Hereford com diferenças no potencial de produção. Os resultados indicaram efeito da K-caseína no peso ao nascimento e ganho de peso até a desmama, representando 15 e $8 \%$ da variação total. 
As características de qualidade da carne são influenciadas por diversos fatores ambientais, idade e sexo do animal e processamento "post-morten". A maturação do músculo em carne ocorre por ação de sistemas proteolíticos. A enzima calpaína parece afetar a proteólise post-morten proporcionando variação na maciez final da carne. A regulação da atividade da calpaína é efetuada pela calpastatina, substância endógena que coexiste em todas as células, configurando um gene candidato para qualidade de carcaça. Green et al. (1994) caracterizaram polimorfismos do gene da calpastatina através da enzima de restrição Taq I e sugeriram uma relação entre este polimorfismo e força de cisalhamento.

\section{Produção e Qualidade do Leite}

A seleção de vacas e touros para produção de leite tem procurado aumentar a produção total, com pouca ênfase para produção de gordura e proteína, devido ao fato de não existir remuneração relativa ao teor destes componentes no Brasil. Outros países remuneram os produtores também em função da gordura e proteína, importantes especialmente para a indústria de laticínios, viabilizando o melhoramento genético dos rebanhos para estas características.

Desde a década passada a caseína, principal proteína do leite, albumina e globulina, proteínas serícas, são consideradas como genes candidatos para produção de leite e seus componentes, tornando-se objeto de diversos estudos e conseqüentemente, variações genéticas nestes locos foram descritas e tentativas de associação com desempenho em termos de produção de leite foram realizadas (Schwerin et al., 1995).

A caseína dos bovinos é subdividida em quatro grandes grupos, $\beta, \alpha 1$, $\alpha 2$ e K- caseínas (Flores \& Richardson, 1988). A K-caseína é responsável pela estabilidade dos micelos, característica importante por ser determinante das propriedades organolépticas dos produtos lácteos (Kemenes, 1996). O alelo B da K-caseína está relacionado com rendimento e qualidade do queijo, talvez, em decorrência de uma maior velocidade de coagulação produzindo coágulos mais

firmes e evitando a perda de gordura (Rampilli et al., 1988). Este alelo, aparentemente, esta associado a um aumento na concentração de proteína, no entanto, foi observado um decréscimo na 
produção total de leite (Bovenhuis, et al., 1992). Os alelos 1 e 2 possuem freqüência 0,92 e 0,08 respectivamente na raça Nelore (Kemenes, 1996; Del Lama, 1996).

A $\beta$-lactoglobulina é transferida para o leite a partir do soro sangüíneo, representando outra fonte de aminoácidos para os lactantes, possuindo duas variáveis principais (A e B) (Kemenes, 1996). Segundo Bovenhuis et al. (1992) ocorre efeito positivo do genótipo BB na concentração de gordura e redução na concentração de proteína e quantidade total de leite também foram encontradas. Este autor demonstrou que o alelo B influencia a caseína do leite, estando associado a uma maior concentração de K-caseína. Kemenes (1996) e Del Lama (1996) encontraram as mesmas freqüências também para $\beta$-lactoglobulina, 0,33 para o alelo 1 (A) e 0,77 para o 2 (B) na raça Nelore.

Os resultados de alguns trabalhos nem sempre se repetem, podendo ser contraditórios. Ron et al. (1993) encontrou efeito significativo em produção de leite, proteína e gordura somente para interação entre os locos em gado holandês de Israel. Velmala et al. (1995) não encontraram efeito significativo para haplótipos de caseína em nenhuma característica de produção.

O hormônio de crescimento "GH" também tem sido sugerido como gene candidato (Hoj et al., 1993). O efeito de substituição do polimorfismo obtido por restrição com a enzima de restrição Alu I em diversas raças de gado de leite foi estudado por Lucy et al. (1993). Os resultados indicaram uma tendência de superioridade do genótipo LL na produção de leite em gado Holandês, entretanto o genótipo VV em Jersey estava associado a uma maior produção. Schlee et al. (1994) encontraram freqüência 0,8 e 0,71 do alelo L (leucina) em gado Holandês e Simental respectivamente. Lucy et al. (1993) obtiveram as freqüências de 1,0, 0,93, 0,92 e 0,56 para PardoSuísso, Holandês, Guernsey e Jersey respectivamente.

Lagsiel et al. (1996) utilizaram a técnica do polimorfismo de conformação de fita simples "SSCP" para configurar haplótipos do hormônio do crescimento encontrados em animais da raça Holandesa criada em Israel e animais de diversas raças zebuínas e taurinas e testar associações com desempenho em termos de produção de leite e seus componentes. Um dos haplótipos encontrados, provavelmente de origem zebuína, apresentou efeito significativo na porcentagem de proteína. Os autores evidenciam a utilidade desta técnica para detectar polimorfismos em genes candidatos como o $\mathrm{GH}$. 


\section{Fertilidade}

O melhoramento genético de características de fertilidade é especialmente importante em bovinos, que possuem uma baixa prolificidade e alto requerimento nutricional anual das vacas em relação ao requerimento total do sistema produtivo. A estimação do valor genético para fertilidade é mais complicada do que para características de crescimento, carcaça ou produção de leite devido, entre outros fatores, a baixa herdabilidade, correlação negativa com outras características, dependência do potencial de crescimento e produção de leite. A seleção para fertilidade, normalmente, é realizada em termos de idade e peso da vaca ao primeiro parto, intervalo entre partos, ausência de doenças reprodutivas e características conformacionais, como por exemplo distância entre ísquios e úbere para vacas e aprumos para touros (Schwerin et al., 1995).

$\mathrm{O}$ uso de marcadores moleculares como critério de seleção indireta para aumentar a eficiência reprodutiva tem se tornado mais atrativo a medida que aumenta a habilidade de detectar polimorfismos a nível molecular. A abordagem do gene candidato deve ser aplicada quando forem conhecidas substâncias que interfiram em mecanismos endócrinos ou fisiológicos controladores da característica de interesse que possuam formas polimórficas detectáveis por técnicas de genética molecular. Por outro lado, marcadores tipo II não são adequados à análise de regiões de importância em fertilidade devido a baixa herdabilidade e controle poligênico (Schwerin et al., 1995). Desta forma, os genes candidatos para estudos de fertilidade seriam os hormônios do eixo hipotalâmico, por exemplo: o hormônio liberador de gonadotropinas " $\mathrm{GnRH}$ ", a ocitocina, o fator inibidor da prolactina "PIF", hormônio folículo estimulante 'FSH", hormônio luteinizante "LH", prolactina, gonadotrofina seríca de égua prenhe "PMSG" seus respectivos receptores e enzimas das vias de biossíntese (Hafez, 1988).

O fenótipo conhecido por "Boroola" foi descrito em ovinos por Bindon \& Piper (1986) sendo responsável por aumento no índice de fertilidade em aproximadamente $20 \%$. Entretanto este loco não foi mapeado até o momento. Associação entre polimorfismo de gene do receptor de estrogênio "ESR" e tamanho de leitegada foi demonstrado em suínos de diferentes raças com efeito de substituição de 0,8 à 1,0 leitões por leitegada (Rothschild et al., 1994). 
Mejdell et al. (1994) estudaram a associação entre antígenos MHC e fertilidade de bovinos da Noruega. Os resultados evidenciaram efeito significativo de alelos BOLA-A no aparecimento de estro. Os autores explicaram este efeito como conseqüência de desequilíbrio de ligação entre MHC e a enzima 21-hidroxilase, relacionada com a biossíntese de glicocorticóides e mineralocorticóides a partir de progesterona.

Schwerin et al. (1995) propõem estudar o efeito do gene "CYP19" codificador da enzima citocromo aromatase P450, enzima reguladora da biossíntese de estrógenos em bovinos (Simpson et al., 1994).

\section{Doenças Hereditárias}

A aplicação da biologia molecular está revolucionando o conhecimento da contribuição genética em doenças de diversas espécies animais e humanas. $\mathrm{O}$ procedimento do gene candidato para uma determinada doença permite que este seja clonado e seqüênciado e quando não estiverem disponíveis genes candidatos, as mutações podem ser localizadas em determinadas regiões cromossômicas através da abordagem por microssatélites (Holmes 1994). A identificação de animais portadores é possível antes da análise de progênie, evitando a que o gene deletério seja transmitido às futuras gerações.

Hoeschele \& Meinert (1990) descobriram uma associação entre produção de leite e a doença mieloencefalopatia degenerativa progressiva "Weaver disease", caracterizada por paresia progressiva dos membros pélvicos e ataxia, em bovinos da raça Pardosuiço. Georges et al. (1994) localizaram este gene próximo ao microssatélite TGLA-116 no grupo sintênico U13, permitindo que seja mapeada a região cromossômica responsável pelo acréscimo na produção de leite. O mapeamento possibilitará desvendar a natureza desta associação, ou seja, se é pleiotropia ou ligação genética, o que direcionará os futuros programas de melhoramento genético.

Pesquisadores dos EUA identificaram o gene responsável pela deficiência na adesão de leucócitos em bovinos "BLAD", doença hereditária bastante freqüênte na descendência do touro Osborndale Ivanhoé. A doença é resultado da substituição do aminoácido 
glicina pelo ácido aspártico na posição 128 da região extracelular da glicoproteína de adesão Integrina- $\beta_{2}$ e é diagnosticada através de "PCR-RFLP" com iniciadores específicos e restrição com a enzima de restrição Taq-I. A frequêencia gênica em populações de gado holandês atinge $15 \%$, acarretando prejuízos da ordem de 5 milhões de dólares nos EUA (Shuster et al., 1992; Healy \& Dennis, 1994, Kehrli, et al., 1994).

A glicogenólise generalizada "Pompe's disease" é uma doença autossômica recessiva causada por uma deficiência da enzima $\alpha$-glucosidase ácida, acarretando um acumulo de glicogênio nos tecidos, sendo reportada inicialmente em humanos e posteriormente em bovinos da raça Brahman por Jolly em 1977. Esta doença geralmente se manifesta aos 6 meses de idade com aumento progressivo de fraqueza muscular e falta de coordenação, quadro que se agrava com o desmame e morte ocorrendo aos 9-12 meses (Reichmann et al., 1994).

Outras doenças hereditárias são: 1) Deficiência da Uridina Monofosfato Sintetase, conhecida por "DUMPS", descrita por Schwenger et al. (1993) é resultado de uma mutação pontual determinante de um "codon" terminal deste gene; 2) Deficiência na coagulação sangüínea devido a uma deleção de 20 pares de base no gene do Fator XI localizado no cromossomo 17 (Robinson, 1994); 3) Citrulinemia, decorrente da ineficiência da argininasuccinato sintetase por substituição de uma par de base que elimina o sítio de restrição da enzima Ava-ll (Dennis et al., 1989), manifesta-se pelo aumento da concentração de amônia e diminuição de arginina no plasma sangüíneo 24 horas após o nascimento, com morte a uma semana de vida. A freqüência gênica observada na raça australiana "Friesien" foi $F(\mathrm{~g})=0,10$ (Shanks et al., 1995). 


\section{Resistência a Doenças Infecciosas}

As moléculas do Complexo Principal de Histocompatibilidade "MHC Major Histocompatibility Complex", conhecido por "HLA -Human Leukocyte Antigen" em humanos, ou "BOLA -Bovine Leukocyte Antigen" em bovinos, foram identificadas como determinantes do controle da rejeição de tecidos transplantados, exercendo importante função no sistema imunológico de vertebrados, incluindo mamíferos, aves, répteis, anfibios e peixes. Atuam no reconhecimento de microrganismos ou moléculas estranhas ao organismos. A função do MHC é se ligar a peptídeos derivados do metabolismo protéico exterior à célula e apresentá-los aos linfócitos $\mathrm{T}$, e desta forma, a apresentação de peptídeos estranhos desencadeia a resposta imunológica (Anderson, 1994)

Os antígenos MHC, codificados em 105 genes contidos em $4.000 \mathrm{~Kb}$, são divididos em Classe I, com 45 locos, expresso em praticamente todos os tecidos, classe II em células do sistema imune (macrófagos e células B), Classe III, bastante heterogênea, envolvidos com comunicação entre células e biossíntese de esteróides e Classe IV em aves, sendo que um loco classe I apresenta 61 alelos diferentes em humanos (Kaufman et al., 1992).

O polimorfismo nestes locos deve ser mantido por seleção balanceada (balancing selection). Algumas evidências que suportam esta afirmação são: 1- As freqüências alélicas são melhores distribuídas do que o esperado para alelos neutros; 2- A freqüência relativa de substituições não sinônimas (substituição que altera a seqüência de aminoácidos) é superior às substituições sinônimas (Hughes \& Nei, 1988, 1989) e 3-Takahata \& Nei (1990) demonstraram que o tempo de persistência dos alelos MHC, milhões de anos, excede o esperado para alelos seletivamente neutros. Este balanceamento das freqüências alélicas parece ser determinado, provavelmente, por interações com patógenos. Dois mecanismos são utilizados para explicar este tipo de seleção (Andersson, 1994): 1- Sobredominância, a freqüência de heterozigotos é superior ao esperado, 2- Seleção dependente das frequeências alélicas, de forma que a vantagem seletiva é inversamente proporcional a sua frequência na população, outra alternativa é o acasalamento preferencial, em que se evita a reprodução entre indivíduos aparentados. 
Uma revisão sobre associação entre polimorfismo de MHC e resistência a doenças foi apresentada por Andersson (1994), onde os haplótipos Classe I aparecem freqüentemente associados com resistência a doenças e os Classe II relacionados a uma maior resposta à vacinação. Mejdell et al. (1994) estudaram a associação entre polimorfismo do BOLA-A e resultados de teste de progênie para resistência a mastite e ketose em gado da Noruega. Berryere et al. (1994) sugerem associação entre o haplótipo 1 de DRB e mastite por Staphylococcus aureus. Xu et al. (1993) indicam associação entre suscetibilidade a linfocitose persistente e BOLA -DRB3.

$\mathrm{O}$ aumento do valor genético para resistência a doenças através da seleção de alelos específicos é improvável, uma vez que a resistência relativa de um determinado genótipo varia entre famílias, assim como entre cepas do patógeno. Além disto, a seleção de determinados alelos poderá aumentar a resistência a uma doença específica, diminuindo para outras e a perda de diversidade de MHC necessitará de milhões de anos para ser restaurada. Estes argumentos evidenciam a necessidade de se manter a diversidade do MHC (Andersson, 1994; Mejdell et al., 1994). Os estudos indicam que uma melhor compreensão da função dos BOLA permitirá produzir vacinas mais eficientes na imunização dos indivíduos de uma população (Andersson (1994).

Olsaker et al. (1993) observaram associação entre uma banda de $16 \mathrm{~Kb}$ obtida através de RFLP do agrupamento genético da lisozima e sua atividade enzimática em bovinos da Noruega. Esta enzima possui ação bactericida por degradar a camada peptidoglicana da parede celular de bactérias estimulando uma resposta do sistema imunológico (Jollès \& Jollès, 1984), estando presente no soro sangüíneo e colostro.

\section{Seleção Assistida por Marcadores Genéticos - MAS}

O melhoramento genético dos animais domésticos tem sido realizado para características de desempenho, como crescimento, produção de leite e eficiência alimentar, aplicando principalmente princípios de genética quantitativa, de modo que, os indivíduos de uma população são avaliados através de metodologias estatísticas que mudaram consideravelmente no decorrer dos anos. 
Os programas de melhoramento genético de bovinos de corte utilizaram, até meados de 1980, a teoria dos índices de seleção com ênfase em seleção dentro de rebanhos em sua grande maioria. A partir daquela data, a metodologia dos modelos mistos para a estimação do valor genético dos animais, expresso em termos de Diferença Esperada Na ProgênieDEP vem apresentando grande destaque (Henderson, 1988; Quass \& Pollak, 1980).

Os resultados do melhoramento genético, a longo prazo, têm sido bastante expressivos, como mostrado por Coutinho \& Regitano (1995). Em frango de corte houve uma redução de 72 para 42 dias para se atingir o peso de abate e na conversão alimentar de 2,338 para 1,77, em 26 anos. Na suinocultura, um animal de 1958-59 apresentava, em média, 3,05 cm de gordura subcutânea e $29,3 \mathrm{~cm}^{2}$ de área de olho de lombo. O suíno moderno possui $1,2 \mathrm{~cm}$ de gordura subcutânea e $35,2 \mathrm{~cm}^{2}$ de área de olho de lombo. Na bovinocultura, um incremento de $1-2 \%$ ao ano tem sido alcançado na produção de leite na última década.

Entretanto, apesar desses resultados, diversas limitações estão se tornando mais aparentes. A eficiência das técnicas tradicionais de seleção é bastante limitada em características de dificil mensuração ou que não podem ser diretamente mensuradas (resistência a doenças, características de carcaça e produção de leite de touros), de baixa herdabilidade (fertilidade), ou que apresentam correlações genéticas negativas (produção de leite e concentração de gordura no leite) (Schwerin et al., 1995).

A análise molecular do genoma dos animais domésticos poderá contribuir para solucionar algumas destas limitações. A capacidade de particularizar características genéticas complexas em entidades mendelianas individuais, ou seja, atribuir efeitos genéticos a segmentos cromossômicos (QTL) ou genes mapeados, permitirá utilizar estas informações em programas de Seleção Assistida por Marcadores (Marked Assisted Selection, MAS) na predição do valor genético. A acurácia das predições e a intensidade de seleção aplicada ao rebanho poderiam ser incrementadas, diminuindo o intervalo entre geração e economizando esforços em testes de progênie de touros. Novas perspectivas para seleção concomitante para diversas características correlacionadas, retenção de heterose, implementação de sistemas de acasalamento para otimizar componentes genotípicos de dominância e epistasia assim como executar introgressão de genes desejáveis a partir de bancos de germoplasma (Soller \& Beckmann, 1983; Beever et al., 1990; Rocha et al., 1992; Bink \& Arendonk, 1994) estarão disponíveis em um futuro próximo. 
Rocha et al. (1994) utilizaram o termo "Ilusão Aditiva" ao se referir a um exagerado otimismo e promessas de fácil emprego de marcadores com propósito de seleção Estes autores afirmam que os fenômenos biológicos freqüêntemente não são aditivos, ou seja, genes isolados não podem ser classificados por bons ou ruins. Somente o genótipo como um todo pode receber este tipo de classificação, ainda assim em relação a determinada condição ambiental. A inconsistência dos resultados verificados em 40 anos de pesquisa envolvendo associação entre características de desempenho e marcadores sangüíneos e do leite suporta este ponto de vista.

O potencial do uso de marcadores moleculares deve ser discutido distinguindo os tipos I e II. Os marcadores tipo I, com efeito direto na característica de interesse, gerados através do procedimento do gene candidato, são dificeis de serem obtidos, mas possuem potencial maior de aplicação do que os tipo II, conhecido por "MAS verdadeira", com efeito indireto baseado em ligação física entre o loco marcador e o "QTL" de interesse (Notter, 1994)

Algumas limitações ao uso de "MAS verdadeira" devem ser consideradas: 1- O tamanho e complexidade das formulações genéticas e metodologias estatísticas necessárias para se determinar a associação. 2- A associação entre um alelo marcador e o "QTL" favorável pode variar dentro e entre populações, e por esta razão a "MAS verdadeira" deve ser empregada somente dentro de família onde o touro é heterozigoto para ambos os locos, ou seja, o touro deve ter a progênie testada para determinar a associação para então aplicar a seleção somente em sua progênie (Notter, 1994). 3- O marcador deve estar adjacente ao "QTL" de interesse, entre 1 e $2 \mathrm{cM}$, para evitar falsa identificação de indivíduos portadores do alelo superior por recombinação entre os locos na progênie. Quanto mais forte a ligação menor a necessidade de novos testes para restabelecer a ligação na descendência (Smith \& Smith, 1993). 4- A maioria das características de importância econômica possuem herança quantitativa, ou seja, sob controle de um grande número de locos "QTLs", de pequeno efeito cada. Entretanto, uma quantidade considerável da variabilidade de características quantitativas pode ser atribuída à segregação de um número relativamente pequeno de "QTLs". Exemplos incluem o gene da hipertrofia muscular em algumas raças bovinas (Nott \& Rollins, 1979), síndrome de estresse em suínos (Ramunsen \& Christian, 1976) e gene boroola em ovinos (Piper \& Bindon, 1988).

Apesar destas limitações a MAS está sendo empregada para detectar doenças hereditárias e gunótipos superiores para caracteristicas de herança simples, como a Síndrome 
do Estresse em Suínos "PSS", Deficiência de Adesão Leucocitária "BLAD" em bovinos (Shuster, 1992). As características determinadas por pequeno número de locos, como coloração de pelagem e presença de chifres também podem ser avaliadas através de marcadores (Georges et al., 1993 a, b). Schmutz et al. (1995) empregaram microssatélites para selecionar animais mochos da raça Charolesa.

Coutinho \& Regitano (1995) citam o uso de marcadores moleculares para realizar introgressão genética, o que permite reduzir o intervalo entre gerações e número de gerações necessárias para isolar o gene "exógeno" de interesse no genoma que se deseja melhorar (Tanksley \& Rick, 1980). O tempo necessário para realizar a introgressão pode ser reduzido ainda mais com o uso da "velogenética" (Massey \& Georges, 1992), em que embriões bovinos de aproximadamente 180-200 dias podem ser geneticamente avaliados e seus oócitos coletados, maturados e fertilizados "in vitro".

O uso de "DNA- fingerprinting" com sondas minissatélite aplicado a introgressão genética foi proposto por Hillel et al. (1990). O processo sugerido baseia-se em retrocruzamentos e seleção dos reprodutores que possuam máxima semelhança genética para a linhagem receptora e mínima semelhança para a linhagem doadora.

A MAS pode ser utilizada também para orientação de acasalamento visando obter máxima heterozigose e conseqüêntemente aumento da produção por heterose. Cepica et al. (1995) obtiveram, em suínos, um aumento significativo da heterozigose na progênie de cruzamentos entre raças selecionadas para máxima distância genética (Nei, 1972) avaliada através de grupos sangǘneos e polimorfismos protéicos. Haberfeld et al. (1996) propõe o uso de "DNAfingerprinting" rotineiramente para orientar acasalamentos em criação de aves. Estes autores obtiveram um aumento no nível de heterose para as características de peso corporal jovem e idade à primeira postura.

\section{Estudos Taxonômicos e Populacionais}

Uma filogenia confiável dos eucariotos é necessária para estudos de características moleculares, celulares e do desenvolvimento. Entretanto, uma filogenia inequívoca não foi obtida através de evidências morfológicas, bioquímicas, citológicas ou fisiológicas devido a 
enorme diversidade dos dados e escassez de achados arqueológicos (Cavalier-Smith 1993; Wainrigth et al., 1993). Estudos envolvendo níveis taxonômicos mais altos tem sido efetuados através da comparação da seqüência nucleotídica ou de mapas de restrição das subunidades ribossomais e uma variedade de proteínas que possuam baixa taxa de mutação e estejam presentes em todos os organismos (Cavalier-Smith 1993; Wainrigth et al., 1993; Nikoh et al., 1994; Kumar \& Rzhetsky, 1996).

Os níveis taxonômicos mais baixos estão sendo estudados através de outras categorias de marcadores moleculares menos conservados, como o RAPD (Teale et al., 1995; Comincini et al., 1996), o DNA mitocondrial (Loftus et al., 1994 a, b) e as regiões satélite do DNA (Ciampolini et al., 1995; Machugh et al,. 1994; Pépin et al., 1995; Modi et al., 1996).

As relações genéticas entre as diferentes raças de bovinos vem sendo objeto de estudos visando esclarecer questões importantes relacionadas à taxonomia, à domesticação e às características peculiares de cada raça (Machugh et al., 1994), assim como, favorecer programas de melhoramento genético e preservação de germoplasma. Pesquisas utilizando grupos sangüíneos e protéicos e conformação do cromossomo Y, revisados por Barbosa (1988), ilustram as distinções entre as raças zebuínas (Bos indicus) da Ásia e África e as taurinas (Bos taurus).

Os marcadores RFLP em DNA mitocondrial, cromossomo $\mathrm{Y}$ além de microssatélites autossômicos foram utilizados por Cunninghan et al. (1995) para estudar as relações genéticas entre gado africano, europeu e asiático. Os resultados evidenciaram uma grande semelhança entre as populações européias e africanas para DNA mitocondrial que diferem aproximadamente $5 \%$ das populações zebuínas. Os dois tipos principais de cromossomo $\mathrm{Y}$ foram observados nas raças africanas sugerindo aos autores que as populações africanas teriam sido formadas a partir de raças européias com migrações recentes de touros zebuínos. As distâncias genéticas obtidas por microssatélites são concordantes com os resultados obtidos para DNA mitocondrial e cromossomo $\mathrm{Y}$.

O polimorfismo de DNA mitocondrial foi utilizado por Loftus et al. (1994 a, b) em populações de gado européias, africanas e indianas para estimar a distância genética entre as raças taurinas e indianas. Os resultados indicam que a divergência entre zebuínos e taurinos ocorreu entre 575.000 e 1.150 .000 anos, bem acima dos 10.000 anos postulado pela hipótese de domesticação única. 
Medjugorac et al. (1994) estimaram as distâncias genéticas de populações de gado europeu através de 86 locos de Grupos sangüíneos, proteínas do sangue e do leite, sugerindo movimentos, em larga escala, destas populações de gado migrando conjuntamente com humanos no período Neolítico, da Ásia para a Europa, através dos Balcãs.

A caracterização de populações zebuínas foi realizada por Zafindrajaona \& Lauvergne (1993) através de grupos sangüíneos e proteínas do leite. Estes autores puderam concluir que as cinco diferentes regiões da ilha de Madagascar possuíam populações semelhantes apresentando freqüência alta do alelo $\mathrm{A}$ de Kapa-Caseína, do alelo $\mathrm{B}$ de $\beta$ Lactoglobulina e cromossomo $\mathrm{Y}$ acrocêntrico.

Um estudo foi realizado em humanos por Bowcock et al. (1994) empregando 30 locos microssatélites em 15 populações indígenas dos 5 continentes. $\mathrm{O}$ resultado do estudo foi a construção de um dendograma a partir das distâncias estimadas e comparação com resultados obtidos com DNA mitocondrial. Machugh et al. (1994) e Ciampolini et al. (1995) ressaltam a utilidade destes marcadores em estudos populacionais intraespecíficos devido a alta taxa de mutação, para a avaliação de bancos de germoplasma, identificação de animais, estudos evolucionários, domesticação e migração, entre outras.

Vaiman et al. (1994) clonaram, localizaram e avaliaram o polimorfismo em 99 microssatélites de bovinos, os quais apresentaram de 4 a 10 alelos e Conteúdo de Polimorfismo Informativo (PIC) variando entre 0,4 e 0,75 para mais de 70\% dos marcadores. Para o microssatélite INRA-006 estes autores obtiveram 7 alelos e PIC 0,51.

Machugh et al. (1994) estudaram seis raças (Aberdeen Angus, Friesian, Hereford, Jersey, Simental e Charolês) de regiões geograficamente distintas da Europa empregando 12 locos microssatélites. A heterozigose variou entre 0,0 e 0,91. Desvios no equilíbrio de HardyWeinberg foram encontrados em alguns locos e o dendograma construído a partir das estimativas de distância genética apresentou concordância com o histórico conhecido das raças.

Ciampolini et al. (1995) investigaram a variabilidade dentro e entre quatro raças italianas de gado de corte (Chianina, Marchigiana, Romagnola e Piemontês) em 220 animais não aparentados. Estes autores estimaram as freqüências alélicas, PIC (conteúdo de polimorfismo informativo), HET (heterozigose), EHW (equilibrio de Hardy-Weinberg) e aprimoraram um método para se calcular a distância genética entre animais e raças através de 
comparações em pares para serem empregados quando estiverem disponíveis um grande número de marcadores polimórficos codominantes (no caso os microssatélites). Os resultados obtidos foram: número total médio de alelos de 10,59, PIC médio de 0,61 e EHW não foi encontrado, para alguns locos. O dendograma indicou uma grande similaridade entre Marchigiana e Romagnola, enquanto o Chianina ocupa uma posição intermediária. O Piemontês é a mais distinta das raças estudadas

\section{Teste de Paternidade}

O correto parentesco entre os indivíduos de uma população é prérequisito para um programa de melhoramento genético eficiente (Van Vleck, 1970; Geldermann et al., 1986; Glowatski-Mullis et al., 1995). A estimação dos parâmetros genéticos populacionais e de mérito genético dos indivíduos através de modelo animal é dependente de genealogia indubitável (Ron et al., 1995), uma vez que estes modelos empregam dados de desempenho de animais aparentados.

Van Vleck (1970) afirma que o aumento no erro de identificação de touros proporciona uma estimativa tendenciosa dos parâmetros genéticos populacionais. Geldermann et al. (1986) sugerem um decréscimo entre 8,7\% e 16,9\% no ganho genético anual em bovinos para uma freqüência de $15 \%$ de erro de identificação. Ron et al. (1995) sugere um acréscimo de $5 \%$ ao ganho genético anual ao realizar teste de paternidade nos 100 filhos dos 50 touros testados anualmente em Israel.

Um pequeno número de identificação equivocada compromete demasiadamente as estimativas de parâmetros genéticos e estudos que envolvem segregação de características fenotípicas e marcadores genéticos (Kinghorn et al., 1993). Além disto, diversas propriedades empregam práticas de manejo que comprometem as informações relacionadas à genealogia, como o uso de reprodutores múltiplos em monta natural ( ${ }^{1}$ Trovo et al. 1997).

' TROVO, J. B. F.; RAZOOK, A. G.; LÔBO, R. B. et al. Avaliações genéticas em bovinos de corte utilizando estruturas de dados não-convencionais. EMBRAPA- CENARGEM, Brasília. (Em elaboração), 1997. 
Uma revisão apresentada por Trovo et al. (1997) cita os autores Poivey e Elsen (1984) como os primeiros pesquisadores a proporem um método de avaliação genética, baseado na teoria dos índices de seleção, de touros incorporando informações de paternidade incertas e Foulley et al. (1987) a desenvolveram um método fundamentado em princípios bayesianos. Ambos os métodos estão baseados na substituição da matriz de parentesco por uma matriz de probabilidades associadas a paternidade de cada progênie com registros de desempenho. Os autores puderam concluir que : 1) na ausência da possibilidade de se determinar a paternidade dos indivíduos envolvidos na estimação do valor genético do touro o emprego da matriz média de parentescos apresenta vantagens com relação a simplesmente desconsiderar os dados da progênie e 2) Futuros trabalhos deveriam considerar as vantagens advindas destas práticas de manejo e o custo relacionado aos testes de paternidade.

Estudos de paternidade em gado bovino, usando grupos sangüíneos $\mathrm{e}$ proteínas do leite, evidenciaram uma alta frequeência de paternidade incorreta em países como Israel

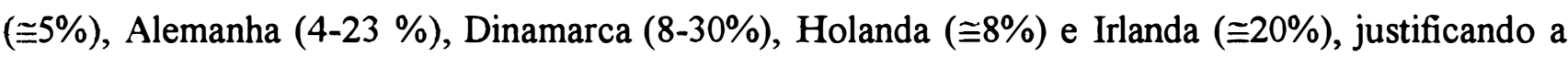
sua utilização em programas de melhoramento genético (Geldermann et al., 1986; Beechinor \& Kelly, 1987; Ron et al., 1995)

Uma característica geneticamente determinada que se expressa ao nascimento e permanece constante durante a vida do indivíduo, não sendo afetada com a idade, por doenças ou condições ambientais, pode ser utilizada para se analisar paternidade. Por exemplo, Gjertson \& Morris (1995) reporta um caso descrito por Archer em 1810 em que uma mulher branca concebeu um par de gêmeos, um branco e outro mulato evidenciando assim que a mulher havia mantido relação sexual com um homem branco e outro negro. Entretanto, a probabilidade de exclusão obtida através de características fisicas pequena. A descoberta das reações de aglutinação $\mathrm{ABO}$ em humanos permitiu incorporar os grupos sangüíneos aos Testes de Paternidade. Os marcadores disponíveis incluem os grupos sangüineos, o MHC- Complexo Principal de Histocompatibilidade, polimorfismos bioquímicos assim como polimorfismos de DNA, como por exemplo RFLP e microssatélites.

As relações de parentesco entre indivíduos podem ser testadas empregando as diversas categorias de marcadores genéticos citados anteriormente. Se o genótipo de um provável touro for incompatível com os genótipos da vaca e progênie este é excluído de 
paternidade. Por outro lado, se os genótipos são compatíveis pode existir duas possibilidades: 1- 0 touro é o progenitor biológico, 2- $\mathrm{O}$ touro possui um genótipo compatível por acaso. A probabilidade de ser descobrir um genótipo incompatível é conhecido por probabilidade de exclusão (PE). Portanto, a PE é a probabilidade de um touro aleatoriamente escolhido ser excluído de paternidade de um par vaca/progênie também escolhidos ao acaso (Dodds et al., 1996).

A fórmula empregada para o cálculo da Probabilidade de Exclusão para marcadores codominantes autossômicos foi descrita por Jamielson (1965). A probabilidade de exclusão associada a Testes de Paternidade vem sendo estudadas por diversos autores (Chakraborty et al., 1974; Crawford et al., 1993; Jamielson, 1994).

$\mathrm{O}$ número de locos e alelos conhecidos têm aumentado tanto para antígenos eritrocitários, quanto para polimorfismos bioquímicos e complexo principal de histocompatibilidade (Salaru, 1993; Glowatzki-Mullis et al., 1995; Jamielson, 1994). Em alguns casos o polimorfismo gerado por estes marcadores é suficiente para uma conclusão definitiva e outros sistemas de marcadores genéticos devem ser utilizados. Gjertson et al. (1988) sugerem uma PE de 0,99 como um valor adequado para a realização do teste de paternidade.

Diversos marcadores moleculares vêm sendo empregados com este intuito, cada qual com suas vantagens e desvantagens. Os RFLPs geralmente fornecem baixa heterozigose e conteúdo de polimorfismo informativo (Litt \& Luty, 1989). Impressões Digitais do DNA obtidas através de sondas minissatélites multilocais são extremamente complexas e bastante informativas, sendo entretanto, dificeis de serem interpretadas por não apresentarem codominância $e$ além disto, alguns casos apresentam bandas de diferentes locos que migram conjuntamente (Jeffreys et al., 1991; Pena e Chakraborty, 1994).

O parentesco determinado por regiões mini e microssatélites loco específico supera muitas das dificuldades associadas a outros tipos de marcadores. Estes marcadores geralmente apresentam uma heterozigose superior à fornecida por RFLPs, sendo de interpretação muito mais fácil do que os padrões gerados por minissatélites multilocais (Jamielson, 1994; Usha et al., 1995). Esta abordagem loco específico vem sendo utilizado na maioria dos laboratórios de Teste de Paternidade em humanos nos EUA (Pena \& Chakraborty, 1994).

As vantagens associadas aos microssatélites grande polimorfismo, boa distribuição, codominância e facilidade de serem obtidos por reação em cadeia da polimerase (PCR), 
o que torna exequível a padronização dos protocolos entre os laboratórios (Glowatzki- Mullis et al., 1995) permitindo, inclusive, o diagnóstico pré-natal (Arroyo et al., 1994; Hammond et al., 1995).

Os microssatélites estão sendo utilizados com este propósito em diversas espécies de animais domésticos como, bovinos (Glowatzki- Mullis et al., 1995; Usha et al., 1995; Vankan et al., 1994), suínos (Hohenhörst et al., 1994), caninos (Dostál \& Stratil, 1994 ) e caprinos (Amigues, et al., 1994). 


\section{3- MATERIAL E MÉTODOS}

\section{1- MATERIAL}

\subsection{1- Tampões}

\section{TAMPÃO DE LISE}

\begin{tabular}{|c|c|}
\hline tris- $\mathrm{HCl}(\mathrm{pH} 7,5) .$. & $.12 \mathrm{mM}$ \\
\hline $\mathrm{MgCl}_{2}$. & $5,0 \mathrm{mM}$ \\
\hline
\end{tabular}

TAMPÃO DE PCR

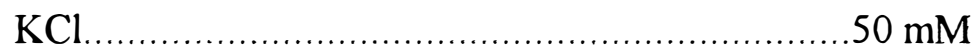

tris- $\mathrm{HCl}(\mathrm{pH} \mathrm{8,3) \ldots \ldots \ldots \ldots \ldots \ldots \ldots \ldots \ldots \ldots \ldots \ldots \ldots \ldots \ldots \ldots ...10} \mathrm{mM}$

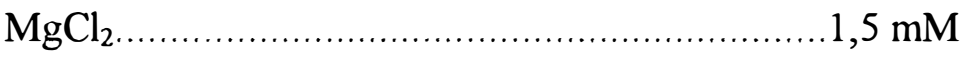

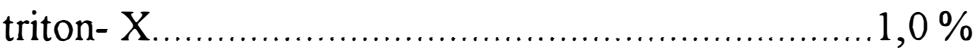

TAMPÃO DE REAÇÃO DA TAQ DNA-POLIMERASE $10 \mathrm{X}$

tris- $\mathrm{HCl}(\mathrm{pH} \mathrm{8,4) \ldots \ldots \ldots \ldots \ldots \ldots \ldots \ldots \ldots \ldots \ldots \ldots \ldots \ldots \ldots \ldots}$

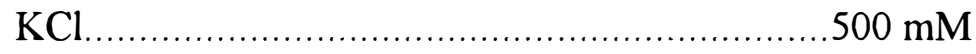

\section{TAMPÃO DO GEL DE POLIACRILAMIDA}

TBE $20 \mathrm{X}$ modificado......................................... $60 \mathrm{ml}$

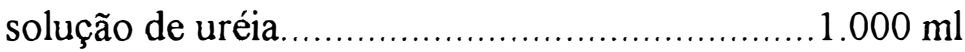




\section{TAMPÃO DE CORRIDA}

TBE $20 \mathrm{X}$ modificado. $.60 \mathrm{ml}$

Completar o volume para $1.000 \mathrm{ml}$

\section{TAMPÃO DE PROTEINASE- K}

$\mathrm{NaCl}$

$.0,375 \mathrm{M}$

EDTA (pH 8,0)......

$0,12 \mathrm{M}$

\section{TAMPÃO DE PARADA (LOADING BUFFER) 6X}

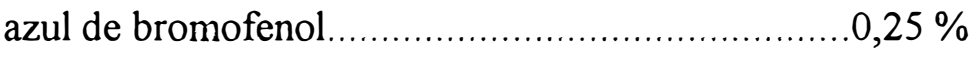

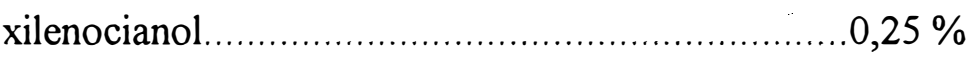

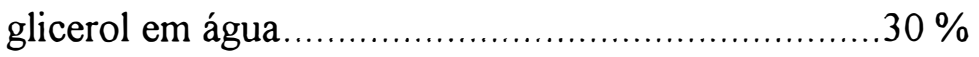

\section{TAMPÃO DE PARADA DESNATURANTE} (LOADING BUFFER) 1,5 X

azul de bromofenol ......................................... $2,5 \mathrm{mg}$

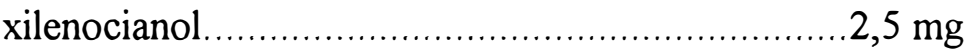

EDTA 0,5 M (pH 7,5) …............................ $0,2 \mathrm{ml}$

formamida ................................................. $4,75 \mathrm{ml}$

\section{TBE 10X ( TRIS- BORATO EDTA)}

tris-base.

$.0,089 \mathrm{M}$

ácido bórico. $0,089 \mathrm{M}$

EDTA $0,5 \mathrm{M}(\mathrm{pH} 8,0)$ $0,002 \mathrm{M}$

Dissolver em $900 \mathrm{ml}$ água Milli-Q, ajustar pH para 8,0 com HCl. Completar o volume para $1.000 \mathrm{ml}$ e esterilizar em autoclave. 
TBE 20X MODIFICADO (TRIS- BORATO EDTA)

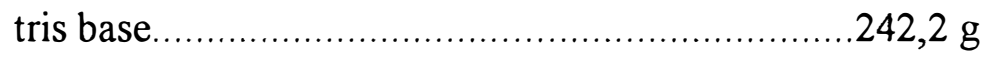

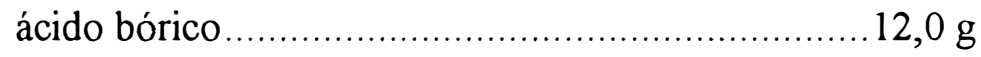

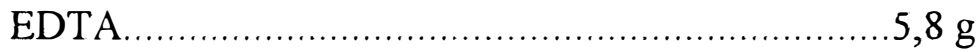

Completar o volume para $1.000 \mathrm{ml}$

\subsection{2- Soluções}

SDS $20 \%$ (SÓDIO DODECYL SULFATO)

SDS.

$200 \mathrm{~g}$

Adicionar $900 \mathrm{ml}$ de água destilada. Aquecer à $68^{\circ} \mathrm{C}$ e agitar para dissolver. Ajustar o $\mathrm{pH}$ para $7,2 \mathrm{com} \mathrm{HCl}$ e ajustar o volume para $1.000 \mathrm{ml}$.

\section{SOLUÇÃO DE URÉIA}

uréia. $612 \mathrm{~g}$

Completar o volume para $1.000 \mathrm{ml}$. Aquecer para dissolver

SOLUÇÃO DE PERSULFATO DE AMÔNIO 10\%

persulfato de amônio $1,0 \mathrm{~g}$

Completar o volume com água MilliQ para $10 \mathrm{ml}$

\section{SOLUÇÃO ÁCIDO ACÉTICO 10\%}

ácido acético $10 \mathrm{ml}$

Completar o volume com água destilada para $100 \mathrm{ml}$ 


\section{SOLUÇÃO DE ACRILAMIDA $\mathbf{4 0 \%}$}

acrilamida...................................................... $38 \mathrm{~g}$

NN'metilbisacrilamida .......................................... 2, $0 \mathrm{~g}$

Completar o volume para $100 \mathrm{ml}$ e aquecer à $37^{\circ} \mathrm{C}$ para dissolver

\section{SOLUÇÃO DO GEL DE POLIACRILAMIDA DESNAT. - 6,67\%}

acrilamida $40 \%$. $10,0 \mathrm{ml}$

tampão do gel $49,65 \mathrm{ml}$

persulfato de amônio $10 \%$ $346,0 \mu 1$

TEMED $34,6 \mu 1$

Adicionar o TEMED na solução sob agitação e rapidamente verter a solução.

\section{SOLUÇÃO DO GEL DE POLIACRILAMIDA NÃO} DESNATURANTE $10 \%$

Acrilamida 40\% $1,5 \mathrm{ml}$

$\mathrm{H}_{2} \mathrm{O}$ $3,36 \mathrm{ml}$ TBE 10\% $0,6 \mathrm{ml}$

Persulfato de Amônio 10\%. $.57,5 \mu 1$

TEMED $2,75 \mu \mathrm{l}$

Adicionar o TEMED e rapidamente verter a solução.

\section{SOLUÇÃO DE REVELAÇÃO}

$\mathrm{Na}_{2} \mathrm{CO}_{3}$ $3,0 \mathrm{~g}$

$\mathrm{HCOH}$ $15 \mathrm{ml}$

$\mathrm{Na}_{2} \mathrm{~S}_{2} \mathrm{O}_{3} .5 \mathrm{H}_{2} \mathrm{O}$ $.0,2 \mathrm{mg}$

Completar o volume para $100 \mathrm{ml}$. 


\section{SOLUÇÃO DE IMPREGNAÇÃO}

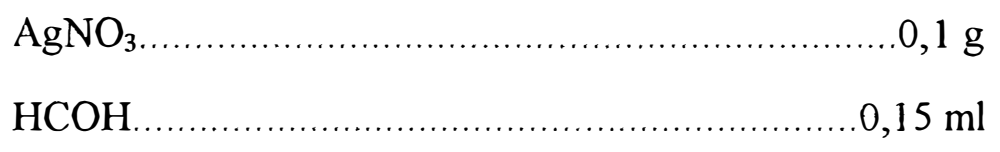

Completar o volume para $100 \mathrm{ml}$.

\section{SOLUÇÃO DE DESIDRATAÇÃO}

ácido acético ............................................ 5,0\%

metanol ................................................... $5,0 \%$

glicerol .................................................... $5,0 \%$

Diluir os componente em água destilada

SOLUÇÃO ESTOQUE DE BROMETO DE ETÍDIO (10 mg / ml)

brometo de etídeo.

$0,05 \mathrm{~g}$

água destilada.

$5,0 \mathrm{ml}$

Armazenar em frasco escuro à $-4^{\circ} \mathrm{C}$.

SOLUÇÃO DE BROMETO DE ETÍDEO $(0,48 \mathrm{mg} / \mathrm{ml})$

solução estoque de brometo de etídeo....................20

água destilada........................................400ml 


\section{2- MÉTODOS}

\subsection{1- Obtenção das Amostras}

O polimorfismo dos marcadores foi avaliado em uma amostra de 63 animais da raça Nelore não aparentados em primeiro grau, 50 provenientes de 21 rebanhos, dentre os participantes da "Prova de Ganho de Peso" de 1995 do Instituto de Zootecnia de Sertãozinho e 13 animais pertencentes à ESALQ-USP.

\subsection{2- Coleta de Sangue}

A coleta de amostra de 5,0 $\mathrm{ml}$ de sangue periférico, foi feita utilizando tubos vacutainer, contendo 7,5 mg de EDTA. Durante a coleta, o sangue foi homogeneizado ao EDTA por inversões do tubo e mantido sob refrigeração em caixa de isopor com gelo e após a coleta à $4^{\circ} \mathrm{C}$ em geladeira até o momento da extração do DNA.

\subsection{3- Extração e Quantificação de DNA}

O DNA foi extraído através de dois métodos, o método descrito em Innis et al. (1989, p 14), e o método de extração e precipitação do DNA em $\mathrm{NaCl}$ (Olerup \& Zetterquist, 1992). 


\section{Método Desenvolvido por INNIS et al. (1989)}

A extração foi efetuada a partir de $0,5 \mathrm{ml}$ de sangue em tubos eppendorf de $1,5 \mathrm{ml}$ de capacidade contendo, além do sangue, 0,5 $\mathrm{ml}$ de solução de lise de eritrócitos. O sangue foi homogeneizado por inversões no tubo eppendorf, sendo então centrifugado à $13.000 \mathrm{~g}$ por 20 segundos. $\mathrm{O}$ sobrenadante foi descartado e o pelete restante ressuspendido em 1,0 $\mathrm{ml}$ de solução de lise com auxilio de um vortex. Este processo foi repetido até a obtenção de um pelete branco.

Após esta etapa o pelete foi ressuspendido em $0,5 \mathrm{ml}$ de tampão de PCR contendo $30 \mu \mathrm{g}$ de Proteinase K. A solução contendo o DNA foi então encubada em banhomaria à $55^{\circ} \mathrm{C}$, por uma hora, sendo então transferido para um banho-maria à $95^{\circ} \mathrm{C}$ por 10 minutos para inativação da enzima.

O DNA foi mantido em freezer à $-20{ }^{\circ} \mathrm{C}$ até $\mathrm{o}$ momento da amplificação, sendo que para cada PCR, foi utilizado $5 \mu$ de solução de DNA.

\section{Método Rápido de Extração e Purificação com Sal}

$\mathrm{O}$ volume de $0,5 \mathrm{ml}$ de sangue, coletado conforme os procedimentos descritos anteriormente, foi adicionado à 1,0 ml de tampão de lise em tubos eppendorf de 1,5 ml.

As amostras foram centrifugadas à $13.000 \mathrm{rpm}$ por 1 minuto, o sobrenadante foi descartado e o pelete ressuspendido em 1,0 $\mathrm{ml}$ de tampão de lise, repetindo-se a centrifugação e descarte do sobrenadante até a obtenção de pelete branco, sendo então lavado em água destilada.

O pelete foi ressuspendido em $80 \mu \mathrm{l}$ de tampão de proteinase $K(5 \mathrm{X})$, $7,0 \mu \mathrm{l}$ de proteinase $(20 \mathrm{mg} / \mathrm{ml}), 10 \mu \mathrm{l}$ de SDS $20 \%$ e $283 \mu \mathrm{l}$ de água destilada e incubado à $55^{\circ} \mathrm{C}$ por 1 hora. Adicionou-se $120 \mu \mathrm{l}$ de $\mathrm{NaCl} 5,0 \mathrm{M}$ e após agitação por 15 segundos a amostra foi centrifugada à 13.000 rpm por 5 minutos. 
O sobrenadante foi transferido para outro tubo onde se adicionou 1,0 $\mathrm{ml}$ de etanol absoluto à $-4^{\circ} \mathrm{C}$, homogeneizado e centrifugado por 5 minutos à $13.000 \mathrm{rpm}$. O sobrenadante foi descartado e o pelete restante foi desidratado. O pelete foi ressuspendido em $100 \mu 1$ de água deionizada.

O DNA foi quantificado em fluorímetro, diluído para possuir uma concentração final de $20 \eta \mathrm{g} / \mu \mathrm{l}$ e mantido em freezer à $-20^{\circ} \mathrm{C}$ até o momento da sua utilização. A cada PCR foi adicionado $5 \mu$ de DNA.

\subsection{4- Reação de Amplificação dos Marcadores RFLP}

As regiões de interesse do DNA foram amplificadas através da técnica PCR, com auxílio de um aparelho termociclador PTC-100 (MJ Research Inc., USA) seguindo um protocolo básico. As reações de amplificação foram conduzidas com o máximo de cuidado para não contaminar as soluções estoque ou o meio de reação, utilizando pipetadores exclusivos para o preparo da mistura de reação.

\section{Protocolo Básico}

A reação de amplificação dos marcadores "RFLP- Restriction Fragment Length Polymorphism" foi efetuada em tubos eppendorf de $0,5 \mathrm{ml}$, o volume final de reação foi $25 \mu \mathrm{l}$ e uma gota de óleo de silicone foi adicionada ao tubo para evitar evaporação das amostras. 


\section{Meio de Reação}

O meio de reação para PCR consistia de:

\begin{tabular}{|c|c|}
\hline $\mathrm{KCl}$. & $.50 \mathrm{mM}$ \\
\hline $\mathrm{MgCl}_{2}$ & $\ldots .1,5 \mathrm{mM}$ \\
\hline Tris- $\mathrm{HCl} \mathrm{pH} 8,4 \ldots \ldots \ldots$ & ........10 mM \\
\hline dNTP (cada).. & $.0,20 \mu \mathrm{M}$ \\
\hline iniciador (cada)... & $0,2 \mu \mathrm{M}$ \\
\hline Taq DNA polimerase.. & $\ldots 0,5$ unidades \\
\hline DNA genômico... & ...100 $\eta g$ \\
\hline
\end{tabular}

\section{Seqüiência de Temperaturas}

A seqüência de temperaturas de desnaturação, anelamento e extensão da reação estão apresentados abaixo:

$\begin{array}{lll}\text { 1- desnaturação inicial } & 95^{\circ} \mathrm{C} & 3 \text { minutos } \\ \text { 2- desnaturação } & 95^{\circ} \mathrm{C} & 1 \text { minuto } \\ \text { 3- anelamento } & \mathrm{TA}^{\circ} \mathrm{C} & 30 \text { segundos } \\ \text { 4- extensão } & 73^{\circ} \mathrm{C} & 1 \text { minuto } \\ \text { 5- repetir 2,3 e } 4 & 29 \text { vezes } & \\ \text { 6- extensão final } & 73^{\circ} \mathrm{C} & 3 \text { minutos } \\ \text { 7- resfriamento } & 4^{\circ} \mathrm{C} & \text { indeterminado }\end{array}$

A $\mathrm{TA}^{\circ} \mathrm{C}$ - temperatura de anelamento e as alterações necessárias para a otimização da reação de amplificação de cada marcador esta indicada a seguir. 


\section{Hormônio de Crescimento}

Uma seqüência de 223 nucleotídeos localizada entre o intron IV e o exon $\mathrm{V}$ do gene do hormônio do crescimento foi amplificada, de acordo com o protocolo apresentado anteriormente, utilizando $200 \eta \mathrm{g}$ de DNA. A temperatura de anelamento foi de $58{ }^{\circ} \mathrm{C}$. Este polimorfismo foi descrito por Schlee et al. (1994) e os iniciadores empregados possuem a seguinte seqüência de nucleotídeos.

GH- UP: $\quad$ 5'- $\quad$ gCT gCT CCT gAg ggC CCT TCg - - ${ }^{\prime}$

GH- DOWN: $\quad$ 5'- gCg gCg gCA CTT CAT gAC CCT - 3'

\section{Kapa- Caseína}

Uma seqüência de $350 \mathrm{pb}$ do loco Kapa-caseína localizada entre os nucleotídeos 201 do exon IV e 149 do intron IV do loco de Kapa-Caseína, foi amplificada. A temperatura de anelamento foi de $55{ }^{\circ} \mathrm{C}$ e a concentração de iniciador $0,4 \mu \mathrm{M}$. Este marcador foi descrito por Medrano \& Cordova (1990a) sendo que os iniciadores possuem a seguinte seqüência de nucleotídeos:

KCN- UP:

5'- ATC ATT TAT ggC CAT TCC ACC AAA g - 3'

KCN- DOWN: $\quad$ 5'- gCC CAT TTC gCC TTC TCT gTA ACA gA - 3' 


\section{$\beta$ - Lactoglobulina}

Uma seqüência de 247 pares do loco $\beta$ - lactoglobulina, localizada entre os nucleotídeos 23 do exon IV e 158 do intron IV foi amplificada utilizando os primers descritos por Medrano \& Cordova (1990b). A concentração de iniciador foi 3,2 $\mu \mathrm{M}$ e a temperatura de anelamento $55^{\circ} \mathrm{C}$.
BLG- UP:
5'- TgT gCT ggA CAC CgA CTA CAA AAA g - -3'
BLG- DOWN:
5'- gCT CCC ggT ATA TgA CCA CCC TCT -3'

\subsection{5- Digestão das Amostras Amplificadas}

O fragmento amplificado de cada marcador foi digerido com enzimas de restrição, conhecidas como endonucleases. Estas enzimas possuem como sítio de restrição a seqüência nucleotídica que se deseja estudar, ou seja, uma mutação no sítio não permite a digestão do fragmento neste loco.

A enzima utilizada para hormônio de crescimento, Kapa-caseína e $\beta$ lactoglobulina foram, respectivamente, Alu I (1,0 unidade), Hinf I (2,5 unidades), Hae III (12,5 unidades).

O fragmento do hormônio de crescimento foi digerido em tubo eppendorf de $0.5 \mathrm{ml}$, e meio de reação contendo $9,0 \mu \mathrm{l}$ de produto de PCR $(\cong 1,0 \mu \mathrm{g}$ DNA)

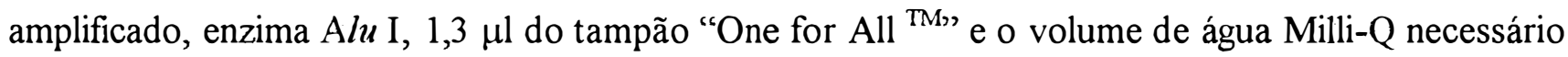
para completar $13,0 \mu$ l. As amostras foram incubadas em banho- maria a $37{ }^{\circ} \mathrm{C}$ por 3 horas. Após a digestão as amostras foram mantidas em freezer a $-20^{\circ} \mathrm{C}$. 
O produto amplificado da Kapa-Caseína foi digerido por 3,0 horas à 37 ${ }^{\circ} \mathrm{C}$ em tubo eppendorf de 0,5 ml, e meio de reação contendo 9,0 $\mu \mathrm{l}$ de DNA, 2,5 unidades da enzima de restrição hinf I e 10\% do tampão de digestão "react 2" e água MilliQ para completar o volume de $13 \mu 1$.

A digestão do fragmento contendo a $\beta$ - Lactoglobulina foi realizada em tubos eppendorf de $0,5 \mathrm{ml}$ por 4,0 horas. O meio de reação foi preparado para possuir $12 \mu \mathrm{l}$ de DNA amplificado, 10 \% de tampão de reação "react 2", 12,5 unidades da enzima de restrição Hae III e água MilliQ para completar o volume de $15 \mu \mathrm{l}$

\subsection{6- Eletroforese}

Após a digestão do produto da amplificação os fragmentos de DNA foram separados em gel de agarose de baixo ponto de fusão (LMP- Low Melting Point) à $3 \%$ dissolvida em TBE 1X, em um sistema de eletroforese horizontal.

O preparo do gel consistiu em pesar a agarose, dissolver em TBE $1 \mathrm{X}$ aquecendo-a em um microondas. A solução foi vertida ao atingir a temperatura de aproximadamente $50-60^{\circ} \mathrm{C}$, na cuba após verificar o nível da mesma. Foi adicionado TBE $1 \mathrm{X}$ após 30 minutos de solidificação, retirado o pente e aplicado $10 \mu \mathrm{l}$ da amostra contendo tampão de parada não desnaturante na proporção de 1 para 5 . Uma diferença de potencial de aproximadamente $5,5 \mathrm{~V} / \mathrm{cm}$ foi aplicada ao sistema por 30 minutos. 


\subsection{7- Visualização dos Fragmentos de DNA}

Os fragmentos de DNA (bandas) dos marcadores RFLP foram detectados através de brometo de etídio. O gel de agarose foi submerso em $500 \mathrm{ml}$ de solução de brometo de etídio à $0,5 \mu \mathrm{g} / \mathrm{ml}$ por 15 minutos, sendo então mergulhados em água destilada por 10 minutos para retirar o excesso de brometo de etídio.

O DNA foi visualizado através da fluorescência do brometo de etídio quando exposto a luz ultravioleta e fotografado com filme polaróide 667.

\subsection{8- Marcação de Iniciadores}

Os "iniciadores Up" de cada marcador microssatélite foram marcados $\operatorname{com} \gamma{ }^{32} \mathrm{P}$-ATP na extremidade 3' através da reação "forward" catalisada pela enzima polinucleotídeo quinase T4- PNK (Amershan). A marcação foi realizada da seguinte forma:

Em um tubo eppendorf de $0,5 \mathrm{ml}$ foi pipetado $200 \mathrm{pmol}$ de "iniciador UP" (5,0 $\mu$ l de solução estoque $40 \mu \mathrm{M})$, adicionado 5,0 $\mu \mathrm{l}$ de tampão de reação $10 \mathrm{X}$ da PNK, 20 $\mu \mathrm{Ci}$ de $\gamma^{32} \mathrm{P}$ - ATP $(1,0 \mu \mathrm{l})$ sendo então centrifugados. Após a centrifugação foi acrescentado $38,0 \mu \mathrm{l}$ de água Milli-Q e 3,0 unidades $(1,0 \mu \mathrm{l})$ de PNK, previamente diluída 1:10. Os tubos foram Incubados a $37^{\circ} \mathrm{C}$ em banho- maria por 1 hora e inativação a $65^{\circ} \mathrm{C}$ por 5 minutos.

\subsection{9- Marcação Radioativa do Padrão de Peso Molecular}

O Padrão de Peso molecular "escada de 10 pares de base (10 bp ladder)", com fragmentos variando entre 10 - 2000 pb foi utilizado como referência para estimação do tamanho dos alelos de cada microssatélite. Este "ladder" foi marcado com $\gamma{ }^{32} \mathrm{P}$ - ATP através da 
reação de troca do fósforo $\gamma$ (exchange reaction) entre o ATP e o oligonucleotídeo utilizando a enzima T4- Polinucleotídeo Kinase (T4- PNK "Ready to go, Pharmacia). O protocolo da reação consistiu de:

Foi adicionado $25 \mu \mathrm{l}$ de água Milli-Q ao tubo da enzima T4- PNK, sendo incubada para dissolver. Foi diluído $340 \mathrm{ng}(3,4 \mu \mathrm{l})$ de padrão em 17,6 $\mu \mathrm{l}$ de água Milli-Q e adicionado ao tubo da enzima. foi acrescentado $20,0 \mu \mathrm{Ci}(4,0 \mu \mathrm{l})$ de $\gamma{ }^{32} \mathrm{P}$ - ATP. O tubo foi centrifugado e incubado a $37^{\circ} \mathrm{C}$ por 60 minutos. A reação foi interrompida com a adição de $25 \mathrm{mM}$ $(5,0 \mu \mathrm{l})$ de EDTA $0,5 \mathrm{M}(\mathrm{pH} 8,0)$ Após o término da reação foi adicionado $\cong 33,34 \mu \mathrm{l}$ de tampão de parada desnaturante.

\subsubsection{0- Reação de Amplificação dos Marcadores Microssatélites}

A reação de amplificação dos microssatélite foi otimizada de acordo com o Protocolo Básico descrito anteriormente para os RFLP, empregando iniciadores não marcados. O produto da amplificação foi visualizado através de eletroforese em gel de agarose e coloração com brometo de etídeo.

Após a otimização, a reação passava a ser efetuada com iniciadores marcados com $\gamma{ }^{32} \mathrm{P}$ - ATP com uma concentração de iniciador reduzida para $0,16 \mu \mathrm{M}$, tanto o “iniciador UP" marcado com $\gamma{ }^{32} \mathrm{P}$ - ATP, quanto o "iniciador DOWN", não marcado. Um aparelho termociclador PTC- 100 foi utilizado para reações em tubos eppendorf de 0,5 ml e em um PTC- 200 para reações em "placa de ELISA" de 96 amostras. 


\section{CSFM-50}

O microssatélite CSFM-50, descrito por Moore et al. (1994) e localizado no cromossomo 2, foi amplificado segundo o protocolo básico descrito anteriormente. A temperatura de anelamento (TA) empregada foi de $55^{\circ} \mathrm{C}$. A seqüência dos iniciadores utilizados foi:

CSFM- UP

CSFM- DOWN
5’- AgT TCT CCT CTT gAT TTC AgT AAC -3’

5'- CCT ACT TCC TgC CTT TgC AgC ATA -3'

\section{INRA-006}

O microssatélite INRA-006, descrito por Vaiman et al. (1995) e localizado no cromossomo 3, foi amplificado segundo o protocolo básico. A temperatura de anelamento (TA) empregada foi de $58^{\circ} \mathrm{C}$. A seqüência dos iniciadores utilizados foi:

INRA-006 UP

5'- Agg AAT ATC TgT ATC AAC CgC AgT C -3'

INRA-006 DOWN 5'- CTg AgC Tgg ggT ggg AgC TAT AAA TA -3’ 


\title{
BM-1224
}

O microssatélite BM-1224, descrito por Bishop et al. (1994) e localizado no cromossomo 4, foi amplificado segundo o protocolo básico descrito anteriormente. A temperatura de anelamento (TA) empregada foi de $54^{\circ} \mathrm{C}$. A sequência dos iniciadores utilizados foi:

\author{
BM-1224 UP 5' $\quad$ Agg AAC CAC ATT ggg TAg TCC -3’ \\ BM-1224 DOWN 5'- TCC CTC TCT CCC TgA ggC -3’
}

IGF-I

O (MS) IGF-I, localizado na extremidade 5' do gene IGF-I, no cromossomo 5 e descrito por Bishop et al., (1994), foi amplificado com temperatura de anelamento de $58^{\circ} \mathrm{C}$. A sequência dos iniciadores utilizados foi:

IGF-I UP $\quad-5^{\prime} \quad$ gCT Tgg ATg gAC CAT gTT $\quad-3$ '

IGF-I DOWN $\quad-5^{\prime} \quad$ CAC TTg Agg ggC AAA Tg A TT -3’ 


\subsubsection{1- Visualização dos Microssatélites}

\section{Eletroforese}

O produto da amplificação, durante a otimização, foi submetido ao sistema Mini-PAGE (eletroforese em mini gel de poliacrilamida) (Sambrook et al., 1989) para visualização dos produtos amplificados. Em cada gel foi aplicado o padrão de peso molecular escada de 10 pb e animais de genótipos conhecidos.

O preparo do gel de poliacrilamida para coloração com prata exigiu cuidados para evitar a formação de "background". As placas de vidro foram lavadas com detergente, submersas em solução de $\mathrm{NaOH} 0,1 \mathrm{M}$ e enxaguadas em água. Um molde formado pelas placas de vidro e os espaçadores, vedado com agarose $1 \%$, serviu de recipiente para a polimerização do gel.

A solução do gel de poliacrilamida foi vertida dentro do molde imediatamente após a adição de TEMED, evitando a formação de bolhas de ar, as quais prejudicariam a migração dos fragmentos de DNA. O molde foi mantido par um período de 1 hora com uma inclinação de $\cong 5$ graus para completar a polimerização.

O gel foi encaixado na cuba, e adicionada o volume adequado de TBE 1X. A amostra contendo tampão de parada não desnaturante na proporção de 1 para 5 foi então aplicada. O sistema foi submetido a uma diferença de potencial de aproximadamente $4,0 \mathrm{~V} / \mathrm{cm}$ por 2 horas. 


\section{Gel de Sequênciamento}

A eletroforese dos microssatélites foi efetuada em gel de sequênciamento devido a necessidade de uma distância de migração de, pelo menos, $30 \mathrm{~cm}$, para uma perfeita separação entre os diferentes alelos, permitindo melhor identificação e estimação do peso molecular. O gel utilizado foi de poliacrilamida desnaturante, para garantir que os polimorfismos encontrados fossem resultantes somente do número de repetições da seqüência núcleo do microssatélites e não alterações na seqüência de nucleotídeos, que em fita dupla podem alterar a velocidade de migração.

O preparo do gel foi semelhante ao Mini-PAGE. As placas de vidro foram lavadas com detergente, submersas em solução de $\mathrm{NaOH}$ 0,1 M por 10 minutos e enxaguadas em água. Um molde formado pelas placas de vidro e os espaçadores, vedado com fita adesiva, serve de recipiente para a polimerização do gel.

A solução de poliacrilamida desnaturante foi vertida dentro do molde rapidamente após a adição de TEMED, evitando a formação de bolhas de ar e esperou-se uma hora para completar a polimerização. O gel foi preparado para possuir $6,67 \%$ de poliacrilamida, $9,5 \mathrm{M}$ de uréia 2,5 mM de persulfato de amônia e 3,8 mM de TEMED.

O gel foi adaptado à cuba, adicionado tampão de corrida até o nível necessário para cobrir as extremidades inferior e superior do gel. Após a montagem da cuba foram aplicados 5,0 $\mu$ de amostra, contendo tampão de parada desnaturante na proporção de 2 para 3 de tampão e DNA respectivamente e $5 \mu \mathrm{l}$ de padrão de peso molecular, após desnaturação à $90^{\circ} \mathrm{C}$ por 15 minutos. Uma potência constante de $40 \mathrm{~W}$ foi aplicada pelo período necessário para a migração dos fragmentos, aproximadamente 3 a 4 horas dependendo do tamanho médio dos alelos.

Após a eletroforese, o gel foi transferido para um papel de filtro, coberto com filme de PCV e desidratado em secador de gel (Savant modelo SGD 2.000) por 1 hora a $80^{\circ} \mathrm{C}$ e pressão negativa de $625 \mathrm{~mm} \mathrm{Hg}$. 


\section{Coloração por Prata}

A visualização das bandas durante a otimização foi realizada por coloração com nitrato de prata (Bassan et al., 1991).

O gel após a eletroforese foi fixado em $100 \mathrm{ml}$ de solução de ácido acético $10 \%$ por 20 minutos, lavado $3 \mathrm{X}$ em água deionizada por 2 minutos e impregnado em $100 \mathrm{ml}$ de solução de impregnação (nitrato de prata) por 30 minutos.

Após esta etapa, o gel foi enxaguado em água deionizada por 20 segundos e submerso em solução de revelação por 2-5 minutos. Esta etapa foi realizada a temperatura entre 20 e $25^{\circ} \mathrm{C}$.

O desenvolvimento da coloração durante a revelação foi interrompido com a imersão em $100 \mathrm{ml}$ de solução de ácido acético $10 \%$ por 10 minutos. O gel foi armazenado em solução de desidratação.

\section{Autoradiografia}

Os géis desidratados foram colocados em cassete, com ou sem ecran, para a exposição aos filmes Hyperfilm ${ }^{\mathrm{TM}}$-MP (Amershan) ou RX (Fuji) à temperatura ambiente. O período de exposição foi determinado com o auxílio de um contador Geiger de acordo com a Tabela 3.

Após o período de exposição os filmes foram revelados, em quarto escuro, através do "KIT Kodak GBX", da seguinte maneira:

O filme foi mergulhado em solução reveladora-reforçadora por 3 minutos, enxaguado em água, fixado por 6 minutos em solução fixadora-reforçadora e lavado em água por 15 minutos. 
Tabela 3: Relação entre período de exposição e contagem por segundo (CPS).

\begin{tabular}{|c|c|c|}
\hline \multirow{2}{*}{ CPS } & \multicolumn{2}{|c|}{ Período de Exposição (dias) } \\
\cline { 2 - 3 } & Período de Exposição com ecran & Período de Exposição sem ecran \\
\hline 20 & 1 & 2 \\
10 & 2 & 4 \\
7 & 4 & 8 \\
5 & 8 & 16 \\
3 & 15 & 30 \\
\hline
\end{tabular}




\section{3- ANÁLISE ESTATÍSTICA}

A constituição genotípica dos indivíduos foi determinada, para cada marcador, através da análise do tamanho e número dos fragmentos. Para os marcadores RFLP, isto significa presença ou ausência do sítio da enzima de restrição. Para os microssatélites, significa o número de repetições da sequeência código.

Estes dados foram utilizados para se estimar a frequência gênica e erro padrão, freqüência genotípica, heterozigosidade, diversidade gênica, conteúdo de polimorfismo informativo. O equilíbrio de Hardy- Weinberg foi testado para cada loco marcador.

\subsection{1- Caracterização da Raça Nelore}

\section{Estimação do Peso Molecular}

O tamanho dos fragmentos foi estimado em função da distância de migração no gel de poliacrilamida, uma vez que fragmentos de DNA desnaturados, migram no gel em função do número de nucleotídeos da cadeia.

O marcador de peso molecular (10 pb) foi adicionado em uma canaleta de cada gel. As distâncias de migração das bandas do marcador e de cada amostra foram medidas com régua. Desta forma pode-se estimar a função logarítimica do tamanho pela distância migrada pelas bandas do marcador, assim como o coeficiente de determinação $\left(\mathrm{R}^{2}\right)$ da curva, com o auxílio do programa EXCEL. 


\section{Freqüência Gênica e Genotípica para RFLP}

Os marcadores moleculares, RFLP e microssatélite, são codominantes, portanto as frequêencia gênicas e genotípicas foram estimadas por contagem simples dos alelos a partir dos resultados observados no gel de eletroforese (Weir, 1990). Os RFLP possuem somente dois alelos, alelo A e alelo B, com freqüência gênica p e q, respectivamente, definidos por:

\section{FREQÜÊNCIA GÊNICA}

$$
\begin{aligned}
& p=\frac{2 N_{A A}+N_{A B}}{2 N} \\
& q=\frac{2 N_{B B}+N_{A B}}{2 N}
\end{aligned}
$$

ERRO PADRÃO DA FREQÜÊNCIA GÊNICA (EP)

$$
E P q=E P p=\sqrt{\frac{p(1-p)}{2 N}}
$$

\section{FREQÜÊNCIA GENOTÍPICA}

$$
\begin{aligned}
& F(A A)=\frac{N_{A A}}{N} \\
& F(A B)=\frac{N_{A B}}{N} \\
& F(B B)=\frac{N_{B B}}{N}
\end{aligned}
$$


Sendo que:

$$
\begin{aligned}
& N_{A A}=\text { número de animais de genótipo AA } \\
& N_{B B}=\text { número de animais de genótipo } \mathrm{BB} \\
& N_{\mathrm{AB}}=\text { número de animais de genótipo } \mathrm{AB} \\
& N=\text { número total de animais da amostra } \\
& p=\text { freqüência do alelo } \mathrm{A} \\
& q=\text { freqüência do alelo } \mathrm{B}
\end{aligned}
$$

\section{Freqüência Gênica e Genotípica para Microssatélites}

Os microssatélites possuem número variável de alelos em diferentes locos e diferentes população, com freqüência $p_{i}$, definida por:

\section{FREQÜÊNCIA GÊNICA $\left(p_{i}\right)$}

$$
p_{i}=\frac{2 N_{i i}+\sum_{i \neq j} N_{i j}}{2 N}
$$

ERRO PADRÃO DA FREQÜÊNCIA GÊNICA (EP)

$$
E P p_{i}=\sqrt{\frac{p_{i}\left(1-p_{i}\right)}{2 N}}
$$

\section{FREQÜÊNCIA GENOTÍPICA (Fii)}

$$
F(i i)=\frac{N_{i i}}{N}
$$


onde:

$$
\begin{aligned}
& N i i=\text { número de indivíduos homozigotos para o alelo } \mathrm{i} \\
& N i j=\text { número de indivíduos heterozigotos para o alelo } \mathrm{i} \\
& p_{i}=\text { freqüência do alelo } \mathrm{i} \\
& n=\text { número total de alelos }(\mathrm{i}=1,2, \ldots, \mathrm{n}) \\
& N=\text { número de indivíduos da amostra }
\end{aligned}
$$

\section{Conteúdo de Polimorfismo Informativo (PIC)}

O conteúdo de polimorfismo informativo (PIC) é freqüentemente utilizado para se avaliar se um loco marcador é adequado para estudos de segregação (Botstein et al., 1980). O PIC representa uma medida da porcentagem dos indivíduos que contribuirão diretamente para a estimação da freqüência de recombinação (Da \& Lewin, 1995), calculado pela fórmula:

$$
P I C=1-\left(\sum_{i=1}^{N} p_{i}^{2}\right) \sum_{i=1}^{N=1} \sum_{i \neq j}^{N} 2 p_{i}^{2} p_{j}^{2}
$$

onde:

$$
\begin{aligned}
& p_{i}=\text { freqüêcia do alelo } \mathrm{i} \\
& p_{j}=\text { freqüêcia do alelo } \mathrm{j} \\
& N=\text { número amostral }
\end{aligned}
$$




\section{Heterozigosidade Intraloco (HET) e Média (HETM)}

Os valores de heterozigosidade por loco (HET), ou como média de todos os locos (HETM) foi calculada de acordo com Weir (1990).

$$
\begin{aligned}
& H E T=1-\sum_{i} p o_{i i} \\
& H E T M=\frac{1}{m} \sum_{l} H E T_{L}
\end{aligned}
$$

\section{Diversidade Gênica Intraloco (DG) e Diversidade Gênica Média (DM)}

$$
\begin{aligned}
& D G=1-\sum_{i} p e_{i}^{2} \\
& D M=1-\frac{1}{m} \sum_{l} D G_{l}
\end{aligned}
$$

Sendo que:

$$
\begin{aligned}
& N=\text { número total de animais } \\
& m=\text { número total de marcadores } \\
& n=\text { número total de alelos } \\
& i=\mathrm{i} \text {-ésimo alelo }(\mathrm{i}=1,2, \ldots, \mathrm{n}) \\
& j=\mathrm{j} \text {-ésimo alelo }(\mathrm{j}=1,2, \ldots, \mathrm{n}) \\
& l=\mathrm{l} \text {-ésimo marcador }(\mathrm{l}=1,2, \ldots, \mathrm{m}) \\
& p o_{j i}=\text { freqüência observada de homozigotos para o alelo } \mathrm{i} . \\
& p e^{2}{ }_{i}=\text { freqüência esperada de homozigotos para o alelo } \mathrm{i}
\end{aligned}
$$




\section{Equilíbrio de Hardy-Weinberg (EHW)}

O Equilibrio de Hardy-Weinberg foi testado para todos os marcadores RFLP e microssatélites pelo Teste Qui-quadrado $\left(\chi^{2}\right)$. A freqüência esperadas para cada classe genotípica foi calculada a partir da freqüência gênica observada. Para evitar freqüências esperadas menores do 5 foi utilizada a técnica de agrupamento para os alelos de baixa freqüência (Smith, 1986).

O número de graus de liberdade do teste é igual ao número de classes fenotípicas menos o número de parâmetros necessários para se calcular os valores esperados nestas classes (Belguelman, 1977). O valor obtido de $\chi^{2}$ foi comparado com o valor do $\chi^{2}$ tabelado no grau de liberdade adequado.

Os valores de Qui-quadrado foram calculados através da fórmula abaixo:

$$
x^{2}=\sum\left[\frac{\left(n_{i_{i j}}-n_{e_{i j}}\right)^{2}}{n e_{i j}}\right]
$$

onde:

$$
\begin{aligned}
& n_{o i j}=\text { número observado de animais da classe genotípica ij } \\
& n_{e i j}=\text { número esperado de animais da classe genotípica ij }
\end{aligned}
$$




\subsection{2- Probabilidade de Exclusão (PE)}

A Probabilidade de Exclusão representa a porcentagem de touros de uma população que será excluída da paternidade de pares vaca/progênie amostrados ao acaso na mesma população. Para o cálculo da probabilidade de exclusão foi utilizada a fórmula descrita por Dodds et al. (1996):

$$
P E=\sum_{i} p_{i}\left(1-p_{i}\right)^{2}-\frac{1}{2} \sum_{i \neq} \sum_{j} p^{2}{ }_{i} p_{j}^{2}\left(4-3 p_{i}-3 p_{j}\right)
$$

onde:

$$
\begin{aligned}
& p_{i}=\text { freqüência do alelo } \mathrm{i} \\
& p_{j}=\text { freqüência do alelo } \mathrm{j} \\
& i=\mathrm{i} \text {-ésimo alelo }(\mathrm{i}=1,2, \ldots, \mathrm{n}) \\
& j=\mathrm{j} \text {-ésimo alelo }(\mathrm{j}=1,2, \ldots, \mathrm{n})
\end{aligned}
$$

\section{Probabilidade de Exclusão Combinada (PEC)}

A probabilidade de exclusão combinada (PEC) representa a porcentagem dos touros de uma população que seria excluída de paternidade em pelo menos um sistema genético. Ron et al. (1995) apresentam a fórmula da Probabilidade de Exclusão combinada da seguinte forma:

$$
P E C=1-\prod_{m}\left(1-P E_{l}\right)
$$

onde:

$$
\begin{aligned}
& m=\text { número total de marcadores } \\
& l=\text { l-ésimo marcador }(1,2 \ldots \mathrm{m})
\end{aligned}
$$




\subsection{3- Probabilidade de Paternidade}

A Probabilidade de Paternidade (PP) ou Probabilidade de Inclusão foi calculada de acordo com os procedimentos descritos por Gjerton \& Morris (1995) e Dodds et al. (1996). As famílias analizadas foram amostradas aleatoriamente dentre os animais que contribuíram para o cálculo das freqüências gênicas.

$$
\begin{aligned}
& P P=1-P n \\
& P_{n}=\sum p_{g g}
\end{aligned}
$$

onde:

$$
P n=\text { soma das freqüências de todos os possíveis genótipos de touros }
$$
compatíveis com os genótipos da vaca e progênie.

$$
p_{g g}=\text { genótipos compatíveis considerando pares de vaca/progênie. }
$$




\section{4- RESULTADOS E DISCUSSÃO \\ 4.1- CARACTERIZAÇÃO DA RAÇA NELORE}

\subsection{1- Determinação dos Genótipos}

\section{Kapa-caseína}

A determinação da constituição genotípica para kapa-caseína foi realizada a partir da amplificação de um fragmento de 350 pares de base e restrição com a enzima Hinf I. Esta enzima possui dois sítios de restrição no alelo 1, gerando 3 fragmentos após eletroforese com respectivamente 134, 132 e 84 pares de base, e somente um sítio no alelo 2, gerando 2 fragmentos com respectivamente, 266 e 84 pares de base, conforme Figuras 1, 2 e 3:

Figura 1. Fragmento amplificado e sítios de restrição para a enzima Hinf I no alelo 1 de Kapacaseína.

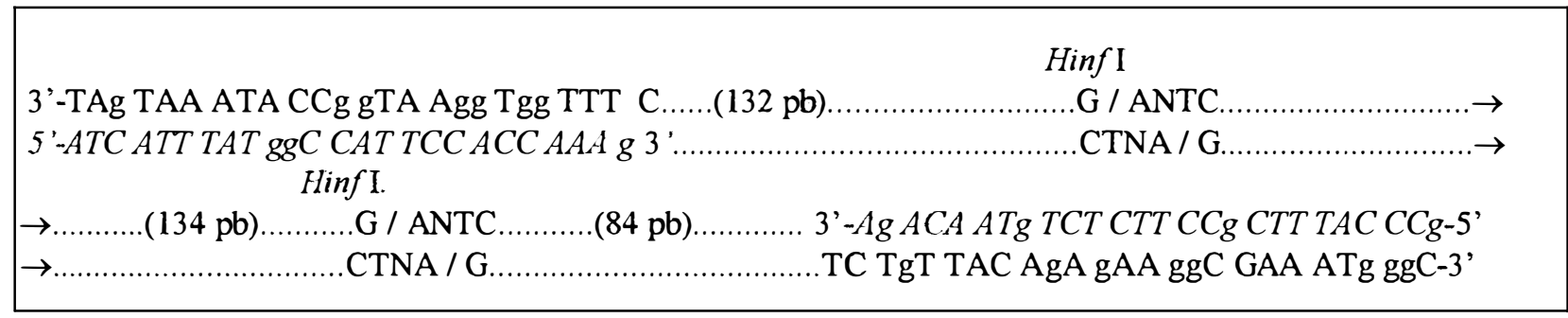

Iniciadores em itálico.

/ = sítio de restrição da enzima $\operatorname{Hinf} \mathrm{I}$.

Figura 2. Fragmento amplificado e sítios de restrição para a enzima Hinf I no alelo 2 de Kapacaseína.

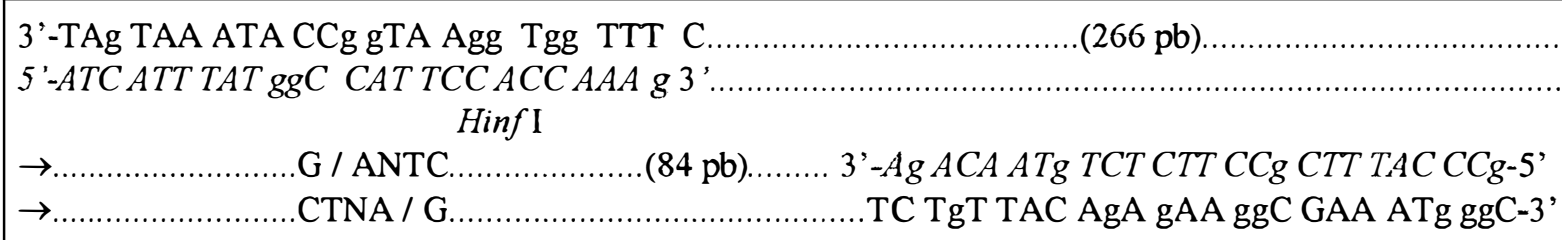

Iniciadores em itálico.

/ = sítio de restrição da enzima $\operatorname{Hinf}$ I. 


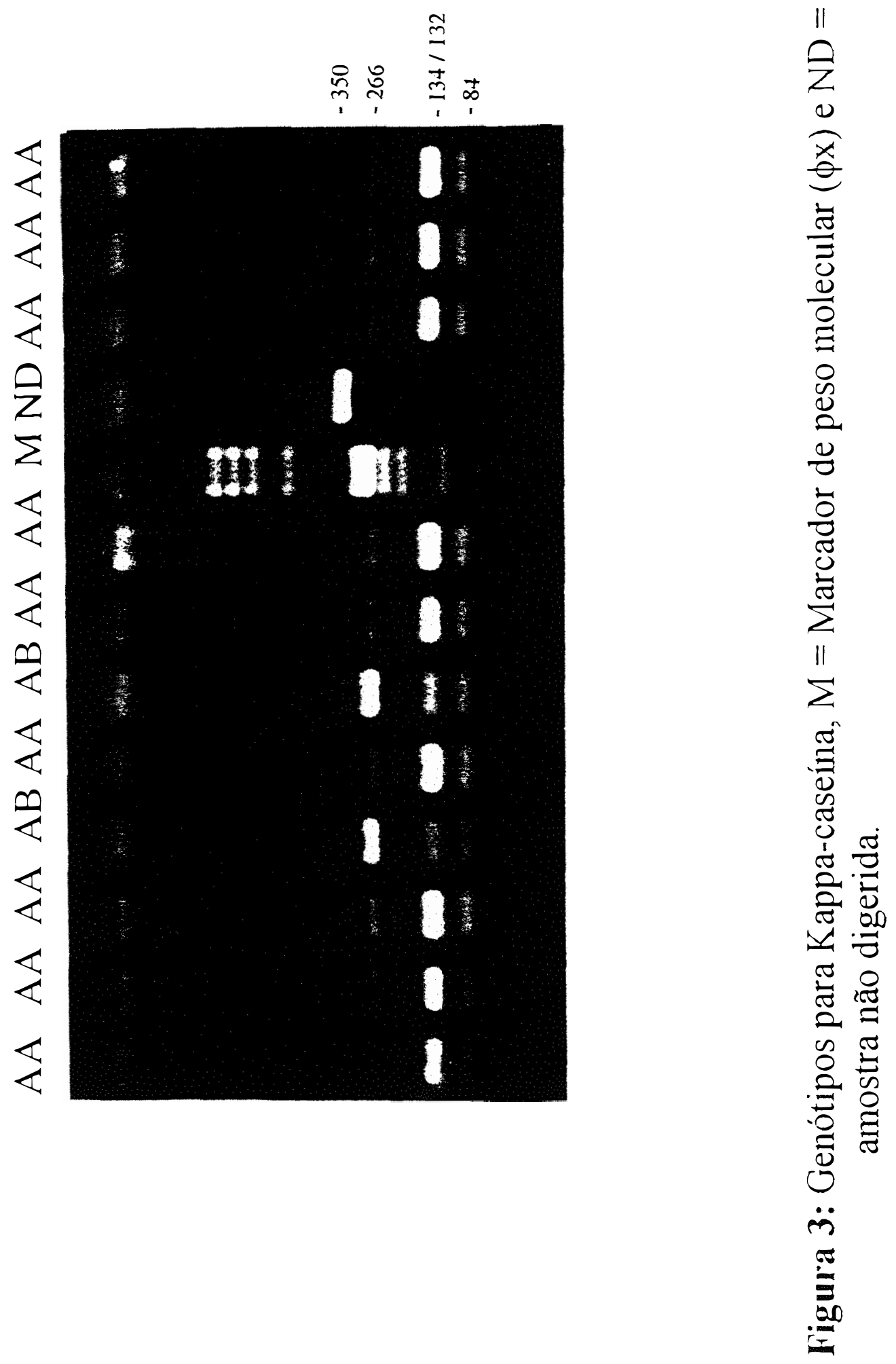




\section{Hormônio do Crescimento}

A determinação dos genótipos para Hormônio do Crescimento foi realizada a partir da amplificação de um fragmento de 223 pares de base e restrição com a enzima Alu I. Esta enzima possui 1 sítio de restrição no alelo 2, gerando 2 fragmentos após eletroforese com respectivamente 171 e 53 pares de base, não apresentando sítio no alelo 1, conforme Figuras 4,5 e 6:

Figura 4. Fragmento amplificado do alelo 1 do Hormônio de Crescimento.

3'-CgA CgA ggA CTC CCg ggA AgC. $(223 \mathrm{pb})$ 3'-TCC CAg TAC TTC ACg gCg gCg-5'

5'-gCT gCT CCT gAg ggC CCT TCg -3'..... Agg gTTC ATg Aag TgC CgC CgC-3'

Iniciadores em itálico.

Figura 5. Fragmento amplificado e sítios de restrição para a enzima $A l u$ I no alelo 2 do Hormônio do Crescimento.

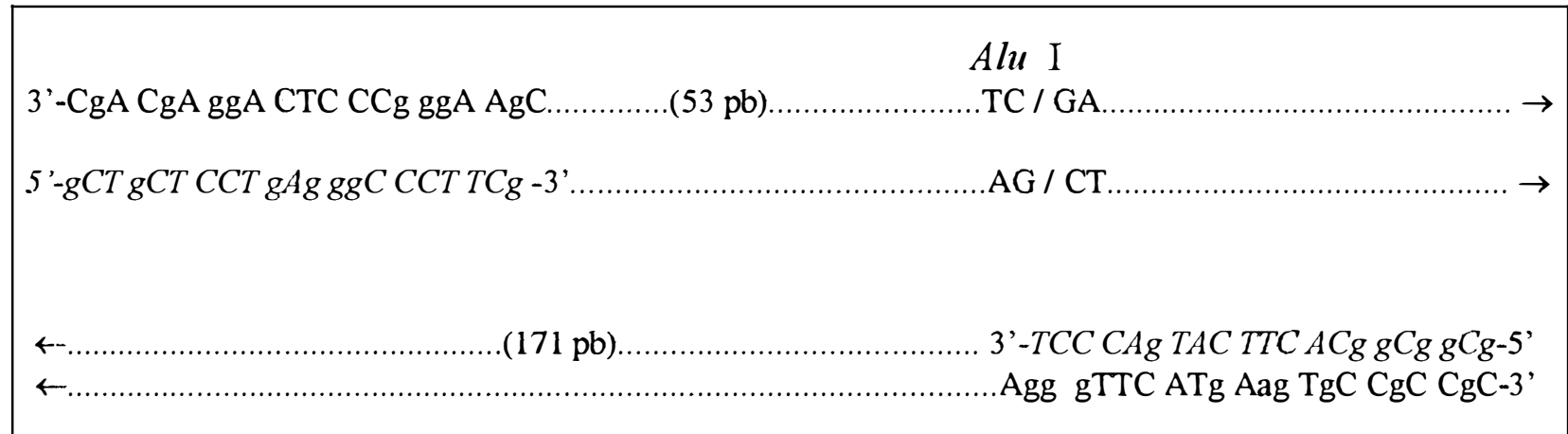

Iniciadores em itálico.

/ = sítio de restrição da enzima Alu I. 


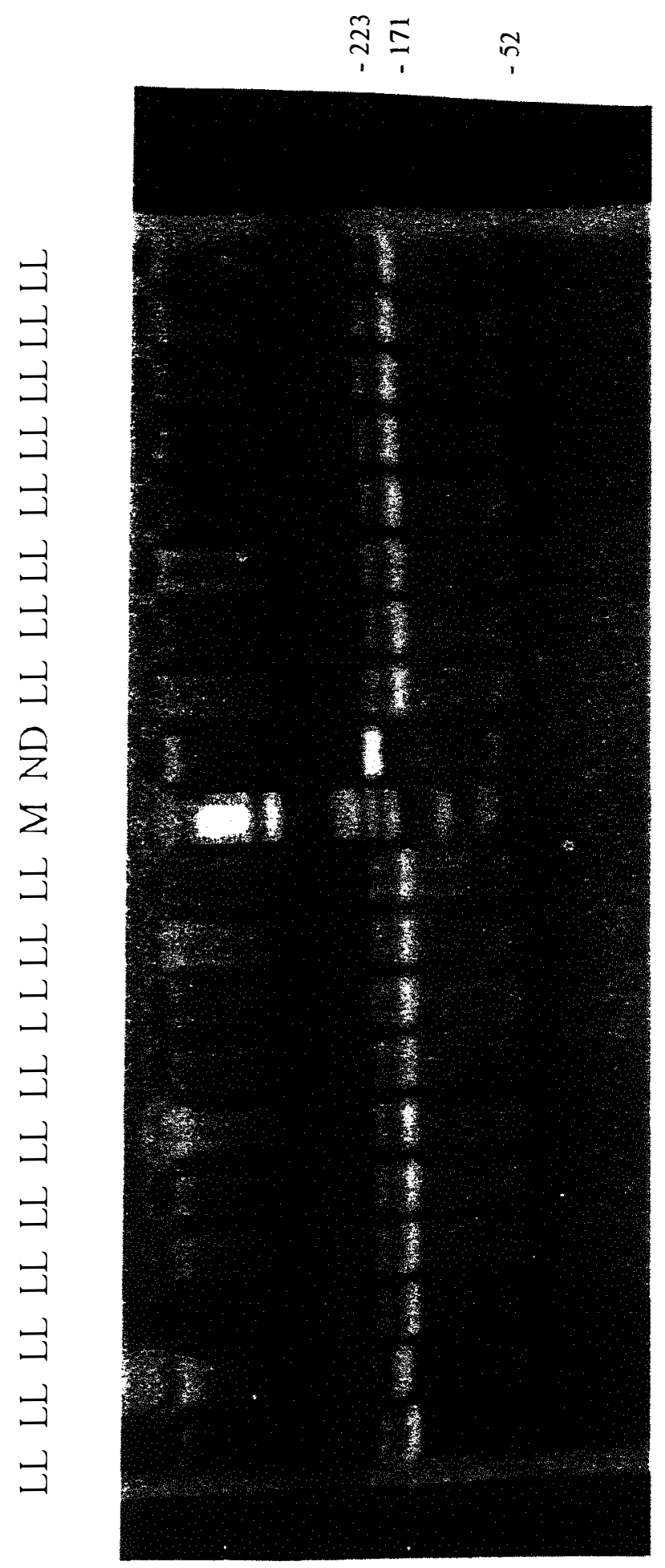

番

3

克

1

$\Sigma$

光

(U)

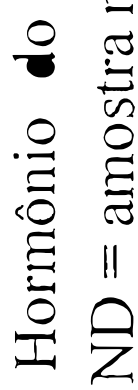

0
0
0

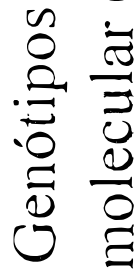

ن

党 


\section{$\beta$ - Lactoglobulina}

Os genótipos para $\beta$ - Lactoglobulina foram determinados a partir da amplificação de um fragmento de 247 pares de base e restrição com a enzima Hae III. Esta enzima possui 1 sítio de restrição no alelo 1 , gerando 2 fragmento após eletroforese com respectivamente 148 e 99 pares de base, e 2 sítios no alelo 2, gerando 3 fragmentos de respectivamente, 99,74 e 74 pares de base, conforme Figuras 7, 8 e 9:

Figura 7. Fragmento amplificado e sítio de restrição para a enzima Hae III no alelo 1 da $\beta$ Lactoglobulina.

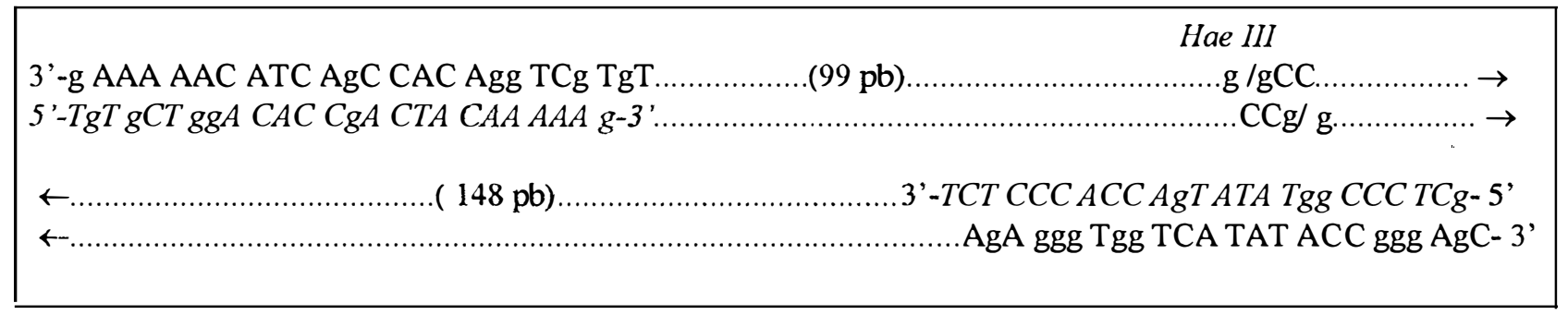

Iniciadores em itálico.

/ = sítio de restrição da enzima Hae III.

Figura 8. Fragmento amplificado e sítios de restrição para a enzima Hae III no alelo 2 da $\beta$ Lactoglobulina.

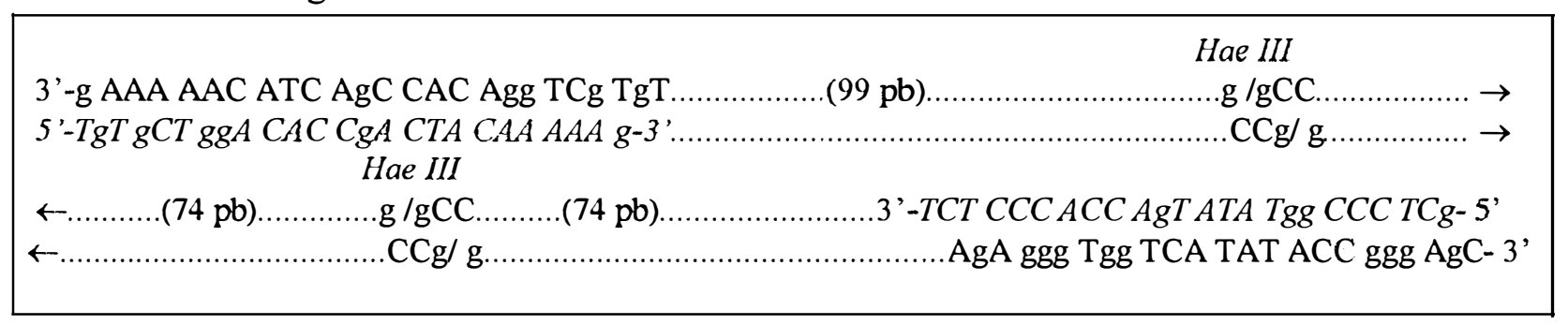

Iniciadores em itálico.

/ = sítio de restrição da enzima Hae III. 


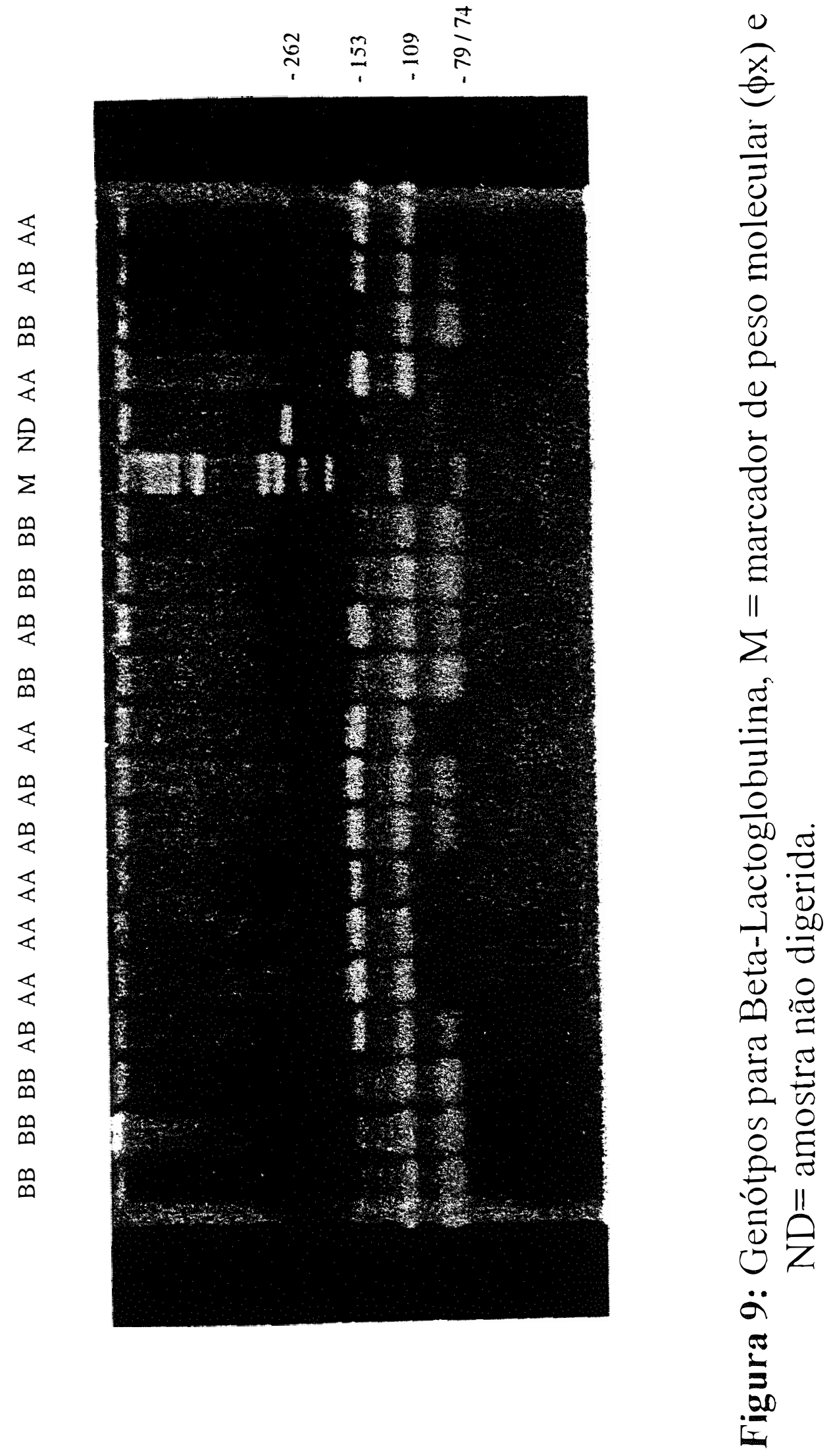


INRA- 006

A determinação da constituição genotípica para INRA-006 foi efetuada a partir da amplificação de um fragmento de 116 pares de base, na média. Este fragmento possui a região microssatélite polimórfica, conforme Figuras 10 e 12:

Figura 10. Fragmento amplificado contendo a região microssatélite INRA- 006.

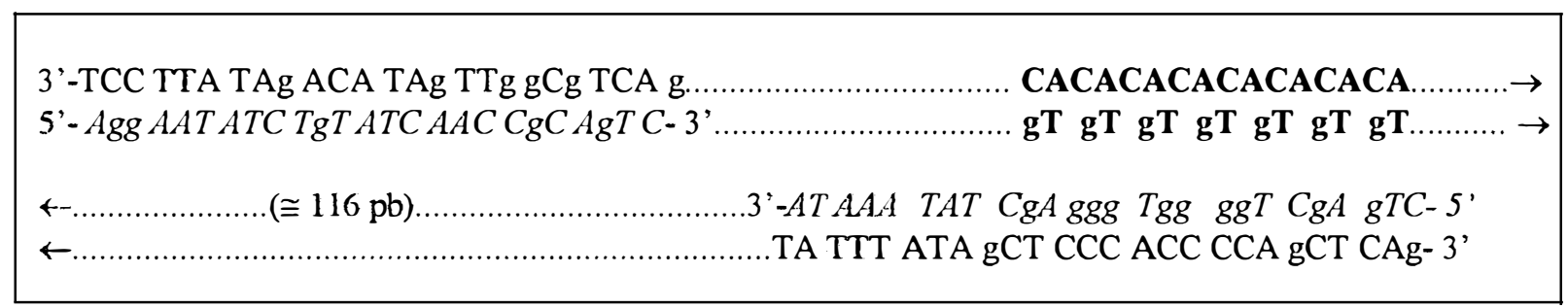

Iniciadores em itálico.

Região microssatélite em negrito

\section{CSFM-50}

Os genótipos para CSFM-50 foram obtidos a partir da amplificação de um fragmento de 178 pares de base, na média. Este fragmento possui a região microssatélite polimórfica, conforme Figuras 11 e 13:

Figura 11. Fragmento amplificado contendo a região microssatélite CSFM- 50.

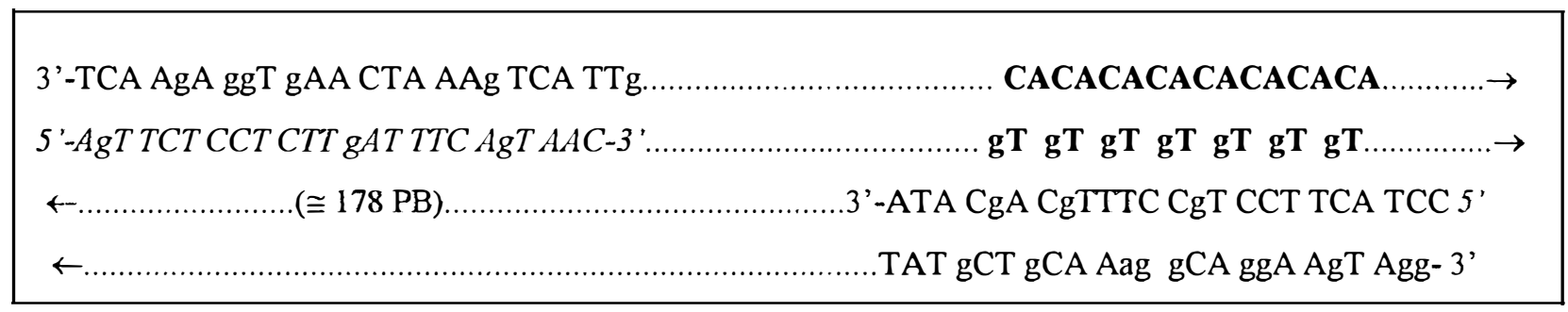

Iniciadores em itálico.

Região microssatélite em negrito 


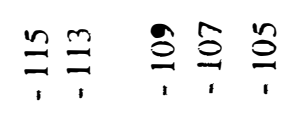

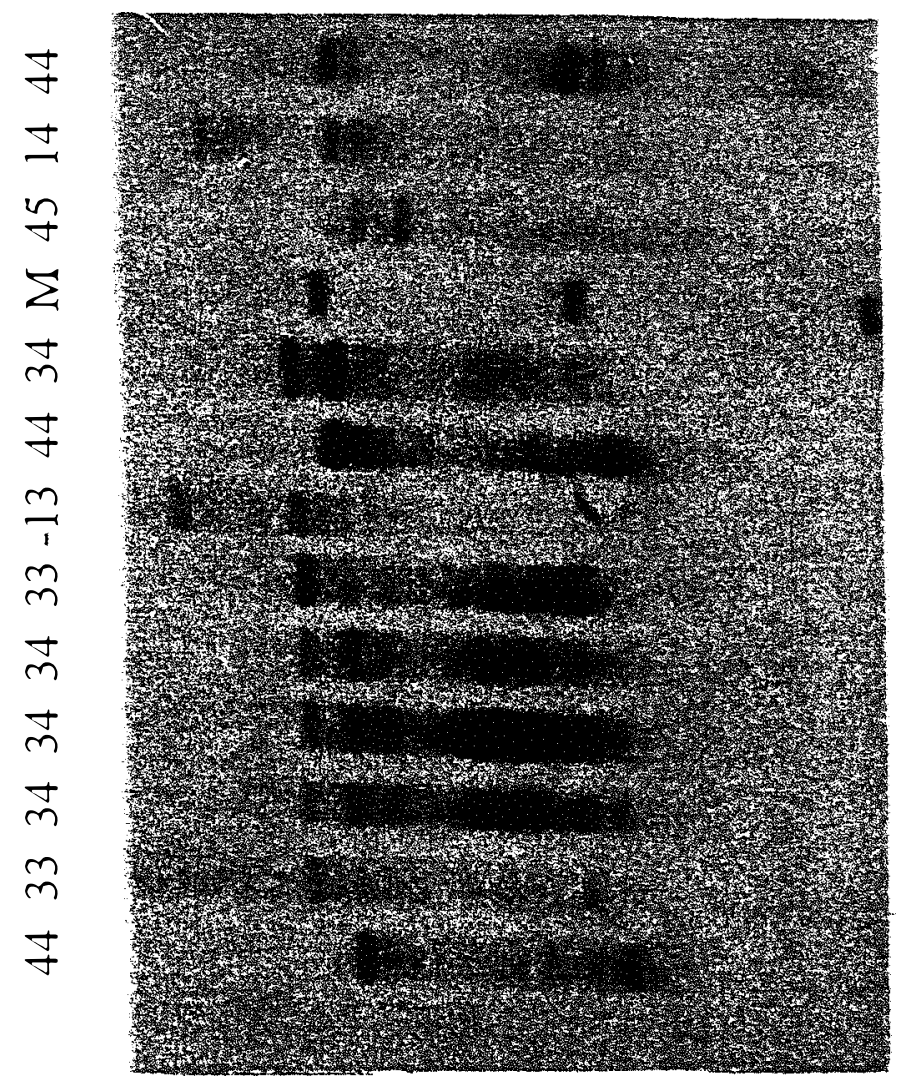

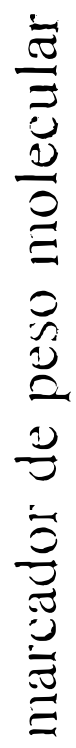

II

$\Sigma$

莒

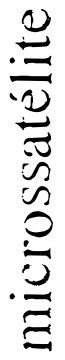

0

承

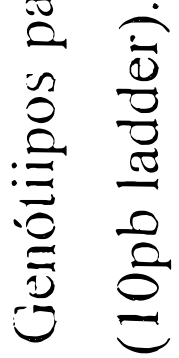

$\ddot{\Xi}$

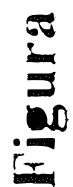



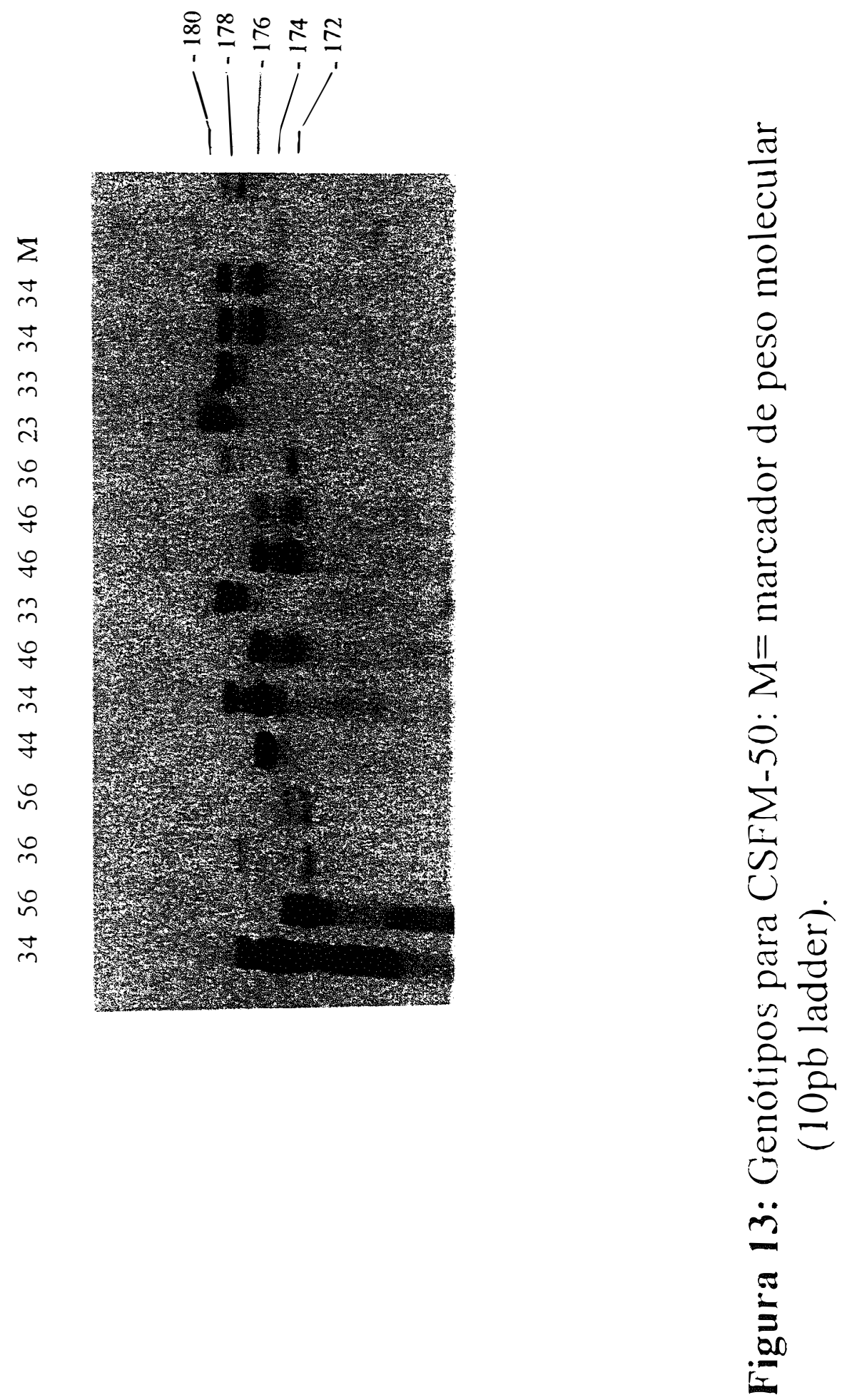

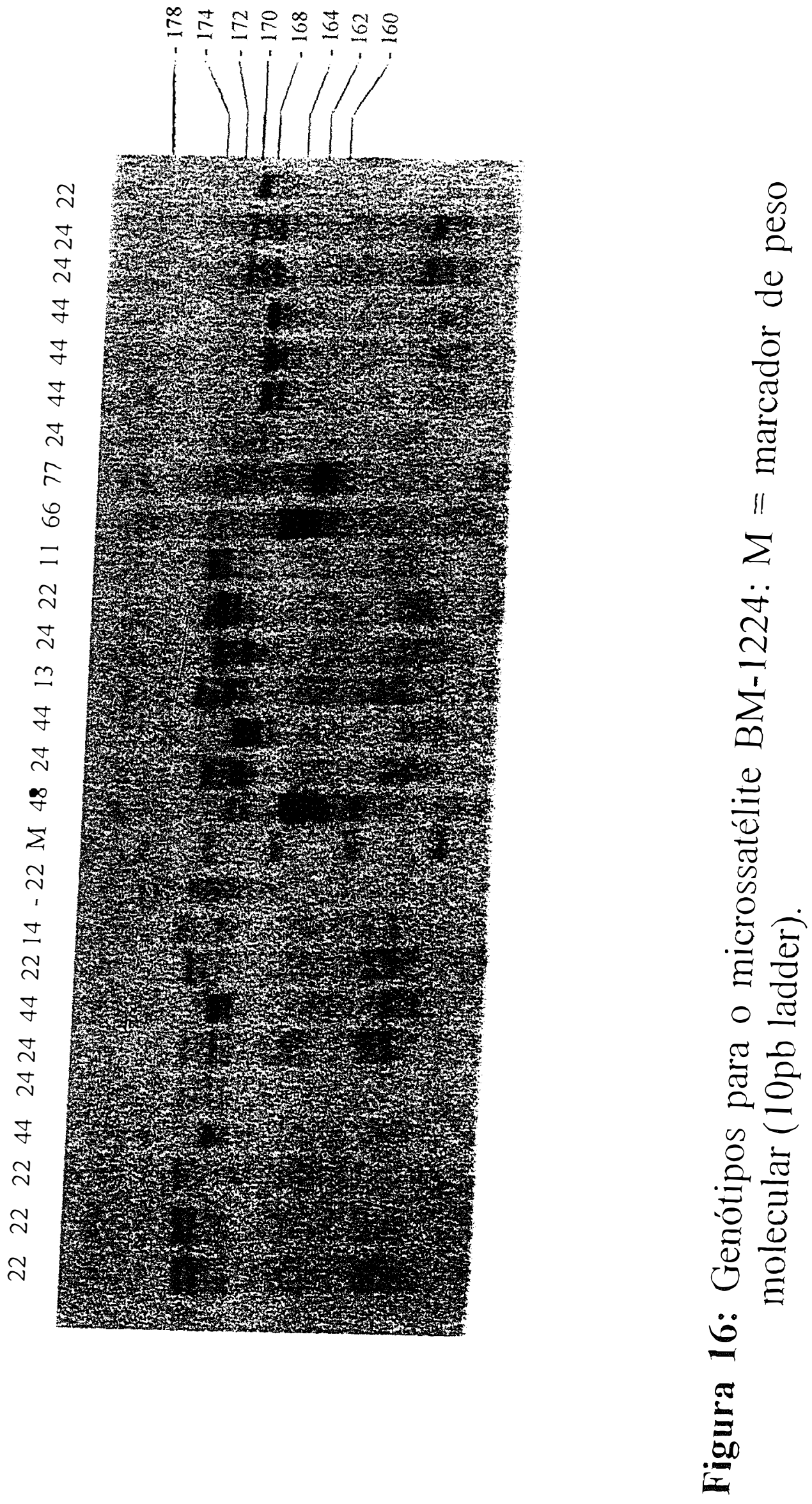


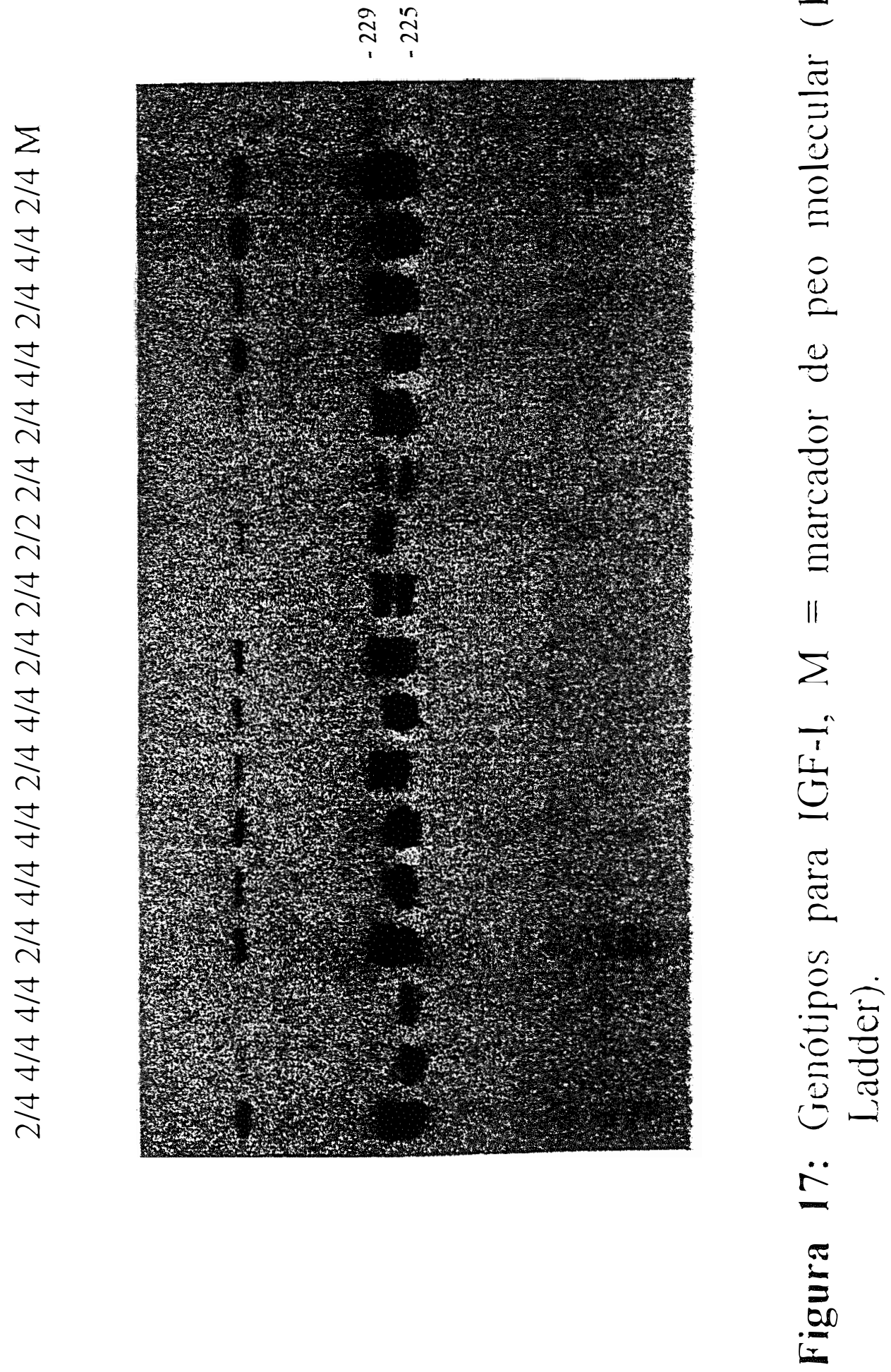




\subsection{2- Freqüiência Gênica para RFLP}

As freqüências gênicas, erros padrão, heterozigosidade, diversidade gênica e conteúdo de polimorfismo informativo para os marcadores RFLP ( Kapa-caseína, $\beta$ lactoglobulina e Hormônio do Crescimento), estão sumarizadas na Tabela 4: .

A amostra obtida da raça Nelore apresentou Equilíbrio de HardyWeinberg para os marcadores estudados e o nível de significância do teste $\chi^{2}$ - Qui-Quadrado esta indicado na Tabela 4 abaixo.

Tabela 4. Freqüências gênicas observadas (freq) e seus respectivos erros padrão (ep), heterozigosidade (Het), diversidade gênica (DG) e conteúdo de polimorfismo informativo (PIC) para os marcadores RFLP Kapa-caseína (KpCs), $\beta$-lactoglobulina ( $\beta$-lact) e Hormônio do Crescimento $(\mathrm{GH})$ e teste $\chi^{2}$ para Equilíbrio de HardyWeinberg (EHW).

\begin{tabular}{|l|l|l|l|l|l|l|l|}
\hline marcador & alelo & freq & ep & Het & DG & PIC & $\chi^{2}$ \\
\hline \multirow{3}{*}{ KpCs } & $(1)$ & 0,913 & 0,025 & 0,175 & 0,16 & 0,147 & 0,56 \\
\cline { 2 - 8 } & $(2)$ & 0,087 & 0,025 & & & & $(\mathrm{~ns})$ \\
\hline \multirow{3}{*}{$\beta$-lact } & & & & & & & \\
\cline { 2 - 8 } & $(1)$ & 0,405 & 0,044 & 0,397 & 0,481 & 0,366 & 1,96 \\
\hline \multirow{3}{*}{ GH } & $(2)$ & 0,595 & 0,044 & & & & $(\mathrm{~ns})$ \\
\hline & & & & & & & \\
\hline & $(1)$ & 1.0 & 0 & 0 & 0 & 0 & \\
\cline { 2 - 8 } & $(2)$ & 0.0 & 0 & & & & \\
\hline
\end{tabular}

ns= não significativo

As freqüências gênicas para os alelos 1 e 2 da Kapa-caseína foram 0,913 e 0,087 respectivamente, concordantes com os resultados encontrados por Kemenes (1996) e por Del Lama et al. (1996), confirmando a baixa freqüência do alelo 2 nesta raça.

Para a $\beta$-lactoglobulina as freqüências gênicas obtidas também foram bastante próximas dos resultados alcançados por Kemenes (1996) e Del Lama et al. (1996). Os alelos 
1 e 2 possuem freqüências 0,405 e 0,595 respectivamente, sendo concordantes com os valores 0,33 e 0,77 encontrados por aquelas autoras.

O hormônio do crescimento não apresentou polimorfismo de substituição do aminoácido leucina/valina na posição 127 na amostra considerada. Lucy et al. (1993) obteve as freqüências 0,0,0,07, 0,08, 0,21, 0,44 para as raças Pardo-suísso, Holandês, Guernsey, Ayrshire e Jersey respectivamente. Coutinho ${ }^{2}$ (1997) avaliou as freqüências em outras raças de bovinos. Os resultados obtidos foram: os zebuínos (Gir e Guzerá) estudados também não apresentaram o polimorfismo, as raças européias (Charolês e Caracu) e raças sintéticas (Canchim e Santa Gertrudes) apresentaram o polimorfismo, com freqüências do alelo (2) $0,178,0,264,0,114$, 0,152 respectivamente

A heterozigosidade, diversidade gênica e conteúdo de polimorfismo calculada para o hormônio do crescimento é igual a 0 uma vez que não existe polimorfismo na amostra. Para $\beta$-lactoglobulina os valores obtidos são relativamente altos levando em consideração a natureza dialélica do marcador. $O$ valor 0,397 é próximo ao máximo $(0,5)$ possível para esta categoria de marcador. A Kapa-caseína apresentou baixa heterozigosidade 0,175 devido a grande diferença entre as freqüências dos alelos 1 e 2 .

Apesar da amostra estar em equilíbrio de Hardy-Weinberg os valores obtidos de heterozigosidade e diversidade diferiram entre si em aproximadamente $10 \%$ para Kapacaseína e $20 \%$ [DL1]para $\beta$-lactoglobulina.

2

\subsection{3- Freqüuência Gênica para Microssatélites}

As freqüências gênicas, erros padrão, heterozigosidade, diversidade gênica e conteúdo de polimorfismo informativo para os marcadores microssatélite, IGF I, BM-1224, CSFM-50 e INRA-006, estão apresentadas nas Tabelas 5, 6, 7 e 8, respectivamente. O Equilíbrio de Hardy-Weinberg não pode ser negado sendo que o nível de significância do teste $\chi^{2}$ Qui-Quadrado esta indicado na Tabela 5 a seguir.

\footnotetext{
${ }^{2}$ Coutinho, Luiz Lehmann. Freqüência gênica para Hormônio do Crescimento. Em elaboração.
} 
Tabela 5. Freqüências gênicas observadas (freq) e seus respectivos erros padrão (ep), heterozigosidade (Het), diversidade gênica (DG) e conteúdo de polimorfismo informativo (PIC) para o marcador microssatélite IGF I e teste $\chi^{2}$ para Equilíbrio de Hardy-Weinberg (EHW).

\begin{tabular}{|l|l|l|l|l|l|l|}
\hline alelo & freq & ep & Het & DG & PIC & $\chi^{2}$ \\
\hline & & & & & & \\
\hline$(2)$ & 0,262 & 0,039 & 0,397 & 0,398 & 0,312 & 0,05 \\
\hline$(4)$ & 0,738 & 0,039 & & & & (ns) \\
\hline & & & & & & \\
\hline
\end{tabular}

ns= não significativo

A amostra analisada da raça Nelore apresentou somente 2 alelos para 0 microssatélite IGF I com freqüências 0,262 e 0,738. Bishop et al. (1994) encontraram 4 alelos em animais de diversas raças zebuínas e taurinas. As raças Charolês e Canchin possuem 3 e 4 alelos respectivamente $\left(\right.$ Regitano $\left.^{3}, 1997\right)$

Os valores obtidos de heterozigosidade $(0,397)$, diversidade gênica $(0,399)$ e conteúdo de polimorfismo informativo $(0,312)$ são relativamente baixos. Uma amostra com maior número de animais poderia evidenciar alelos raros, entretanto isto não mudaria significativamente os valores de heterozigosidade, diversidade gênica e conteúdo de polimorfismo informativo.

O marcador BM- 1224 apresentou 7 alelos nos animais avaliados $(-2,1$, $2,4,6,8,11$ ), com freqüências $0,008,0,048,0,46,0,278,0,119,0,079,0,008$ respectivamente. As raças Charoles e Canchin possuem 9 e 6 alelos respectivamente (Regitano ${ }^{3}$, 1997). Bishop et al. (1994) encontraram 6 alelos em animais de diversas raças zebuínas e taurinas.

Os valores obtidos de $[\mathrm{F}-\mathrm{DG} 2]^{3}$ heterozigosidade $(0,508)$, diversidade gênica $(0,688)$ e conteúdo de polimorfismo informativo $(0,642)$ são relativamente baixos, apesar do número satisfatório de alelos as suas freqüências não são semelhantes, com dois alelos (2 e 4) totalizando aproximadamente $75 \%$ da população.

\footnotetext{
${ }^{3}$ Regitano, Luciana C. A. Polimorfismo molecular em gerações de bovinos da raça Canchim. Tese de Doutorado, 1997. Em Elaboração.
} 
Tabela 6. Freqüências gênicas observadas (freq) e seus respectivos erros padrão (ep), heterozigosidade (Het), diversidade gênica (DG) e conteúdo de polimorfismo informativo (PIC) para o marcador microssatélite BM- 1224 e teste $\chi^{2}$ para Equilibrio de Hardy-Weinberg (EHW).

\begin{tabular}{|l|r|r|l|l|l|r|}
\hline alelo & freq & ep & Het & DG & PIC & $\chi^{2}$ \\
\hline & \multicolumn{2}{|r|}{$\mid$} & & & & \\
\hline$(-2)$ & 0,008 & 0,008 & & & & \\
\hline$(1)$ & 0,048 & 0,019 & 0,508 & 0,688 & 0,642 & 8,21 \\
\hline$(2)$ & 0,460 & 0,044 & & & & $(\mathrm{~ns})$ \\
\hline$(4)$ & 0,278 & 0,040 & & & & \\
\hline$(6)$ & 0,119 & 0,029 & & & & \\
\hline$(8)$ & 0,079 & 0,024 & & & & \\
\hline$(11)$ & 0,008 & 0,008 & & & & \\
\hline
\end{tabular}

ns= não significativo

Tabela 7. Freqüências gênicas observadas (freq) e seus respectivos erros padrão (ep), heterozigosidade (Het), diversidade gênica (DG) e conteúdo de polimorfismo informativo (PIC) para o marcador microssatélite CSFM- 50 e Equilíbrio de HardyWeinberg (EHW).

\begin{tabular}{|l|r|r|l|l|l|r|}
\hline alelo & freq & ep & Het & DG & PIC & $\chi^{2}$ \\
\hline & & & & & & \\
\hline$(3)$ & 0,016 & 0,011 & & & & \\
\hline$(4)$ & 0,270 & 0,040 & 0,81 & 0,642 & 0,696 & 4,48 \\
\hline$(6)$ & 0,246 & 0,038 & & & & ns \\
\hline$(7)$ & 0,151 & 0,032 & & & & \\
\hline$(8)$ & 0,317 & 0,041 & & & & \\
\hline
\end{tabular}

ns= não significativo

A amostra da raça Nelore apresentou 5 alelos $(3,4,6,7,8)$ para o microssatélite CSFM-50 com freqüências 0,016,0,270,0,246, 0,151 e 0,317 respectivamente. As raças Charoles e Canchin possuem 6 e 6 alelos respectivamente (Regitano ${ }^{3}$, 1997).

Os valores obtidos de heterozigosidade, diversidade gênica e conteúdo de polimorfismo informativo foram $0,810,0,642$ e 0,696 respectivamente. Estes valores foram 
obtidos devido a existência de 4 alelos com freqüências alélicas bem distribuídas, com 15 a $20 \%$ aproximadamente.

Tabela 8. Freqüências gênicas observadas (freq) e seus respectivos erros padrão (ep), heterozigosidade (Het), diversidade gênica (DG) e conteúdo de polimorfismo informativo (PIC) para o marcador microssatélite INRA-006 e teste $\chi^{2}$ para Equilíbrio de Hardy-Weinberg (EHW).

\begin{tabular}{|l|r|r|l|l|l|r|}
\hline alelo & freq & ep & Het & DG & PIC & $\chi^{2}$ \\
\hline & & & & & & \\
\hline$(-3)$ & 0,151 & 0,032 & & & & \\
\hline$(-1)$ & 0,008 & 0,008 & 0,713 & 0,735 & 0,701 & 4,15 \\
\hline$(1)$ & 0,016 & 0,011 & & & & (ns) \\
\hline$(3)$ & 0,190 & 0,035 & & & & \\
\hline$(4)$ & 0,429 & 0,044 & & & & \\
\hline$(5)$ & 0,087 & 0,025 & & & & \\
\hline$(9)$ & 0,119 & 0,029 & & & & \\
\hline
\end{tabular}

$\mathrm{ns}=$ não significativo

A amostra analisada da raça Nelore apresentou 7 alelos $(-3,-1,1,3,4$, $5,9)$ para o microssatélite INRA-006 com freqüências $0,115,0,008,0,016,0,19,0,429,0,087,0,119$ respectivamente. As raças Charoles e Canchin possuem 3 e 7 alelos respectivamente (Regitano ${ }^{3}$, 1997). Vaiman et al. (1994) encontraram 7 alelos, com PIC 0,54, em animais de diversas raças taurinas.

Os valores de heterozigosidade, diversidade gênica e conteúdo de polimorfismo informativo foram $0,713,0,735$ e 0,710 respectivamente, superior ao encontrado por Vaiman et al. (1994). Estes valores foram obtidos devido a existência de 5 alelos com freqüências próximas ou superior à $10 \%$. 


\section{2- PROBABILIDADE DE EXCLUSÃO}

A probabilidade de exclusão (PE) de touro ou vaca foi calculada para os diversos marcadores genéticos autossômicos utilizando as freqüências gênicas estimadas dos alelos encontrados na amostra.

Os resultados da probabilidade de exclusão para cada marcador e probabilidade de exclusão combinada para todos os marcadores utilizados, ou seja, probabilidade de ocorrer exclusão de paternidade em pelo menos um sistema genético estão sumarizados na Tabela 9.

Tabela 9. Probabilidade de exclusão (PE) para cada marcador genético e probabilidade de exclusão combinada (PEC) para todos os marcadores.

\begin{tabular}{|l|l|l|l|ll|l|l|l|}
\hline & KpCs & $\beta$-lact & GH & IGF I & CSFM-50 & BM- 1224 & INRA-006 & PEC \\
\hline PE & 0,0731 & 0,1759 & 0 & 0,1560 & 0,5077 & 0,4406 & 0,5210 & 0,9089 \\
\hline
\end{tabular}

A probabilidade de exclusão obtida para o Hormônio do Crescimento foi igual a zero. Determinar a procedência dos alelos é impossível uma vez que não existe polimorfismo para este loco.

A probabilidade de exclusão para a Kapa-caseína $(0,0731)$ é bastante baixa em decorrência polimorfismo encontrado, ou seja, existem somente dois alelos, sendo que o alelo 1 possui freqüência 0,913 .

O marcador $\beta$-lactoglobulina apresentou a maior probabilidade de exclusão $(0,1759)$ entre os RFLP devido à freqüência de seus alelos, próximo ao máximo possível para marcadores dialélicos codominante. Quando $\mathrm{p}=0,5(\mathrm{PE} \cong 0,1875)$.

$\mathrm{O}$ marcador microssatélite IGF I apresentou uma PE muito baixa $(0,1560)$ para um marcador microssatélite, não sendo adequado para a realização de teste de paternidade uma vez que poucas relações de parentesco seriam resolvidas neste sistema genético.

Os resultados de PE 0,5210, 0,4406 e 0,5077 obtidos para os microssatélites INRA-006, BM-1224 e CSFM-50, respectivamente, foram satisfatórios. 
A $\operatorname{PEC}(0,9089)$ entretanto, esteve aquém do ideal $(0,99)$. A probabilidade de exclusão combinada (PEC) para sete marcadores com $\mathrm{PE} \cong 0,5$ seria aproximadamente 0,992 . Uma PEC da mesma magnitude $(0,991)$ seria alcançada com somente quatro marcadores com $\mathrm{PE} \cong 0,7$

\section{3- TESTE DE PATERNIDADE}

As famílias participantes do Teste de Paternidade estão apresentadas na Figura 18, e os respectivos genótipos na Tabela 11.

A análise dos genótipos das 13 famílias touro/vaca/progênie participantes do teste de paternidade, possibilitou a exclusão de paternidade em dois casos. As famílias 373/374/ 375 e a 373/380/ 381 foram excluídas em três sistemas genéticos microssatélite (BM-1224, CSFM-50 e INRA-006) e um sistema (BM-1224), respectivamente.

Os sistemas genéticos RFLP e o microssatélite IGF I não excluíram paternidade em nenhuma das famílias, evidenciando a baixa utilidade destes marcadores para teste de paternidade.

A freqüência de erro de identificação encontrado neste teste foi aproximadamente $15,4 \%(2 / 13)$, próxima aos valores obtidos por outros autores em outros países, citados por Ron et al. (1995). Apesar do pequeno número de famílias estudadas neste teste, este valor pode refletir a realidade brasileira.

O cálculo da probabilidade de paternidade foi realizado em todas as famílias em que não ocorreu exclusão de paternidade, pois neste caso a probabilidade de paternidade é igual a zero.

A proporções de touros excluídos, considerando os genótipos da vaca e progênie variou dentro de marcador, em função da freqüência do provável alelo paterno,. Por exemplo, a Kapa-caseína apresentou proporções variando de zero (não foi possível excluir nenhum touro da população) à 0,83 , quando o alelo paterno era o 2. O valor mínimo obtido para o BM-1224 foi 0,0688 , enquanto o máximo foi 0,9913 . 
Este fato evidencia a necessidade de uma caracterização confiável das diferentes linhagens dentro da raça que se deseja realizar o teste de paternidade, uma vez que diferentes populações não apresentam necessariamente as mesmas freqüências alélicas. Além disto, freqüentemente os testes de paternidade ignoram as relações de parentesco entre os animais envolvidos no teste, isto poderia levar a um resultado de probabilidade de paternidade tendencioso (Balding \& Nichols, 1995). 


\subsection{1- Familias Estudadas no Teste de Paternidade}

Na Figura 18 estão apresentadas as 13 famílias amostradas aleatóriamente para o Teste de Paternidade.
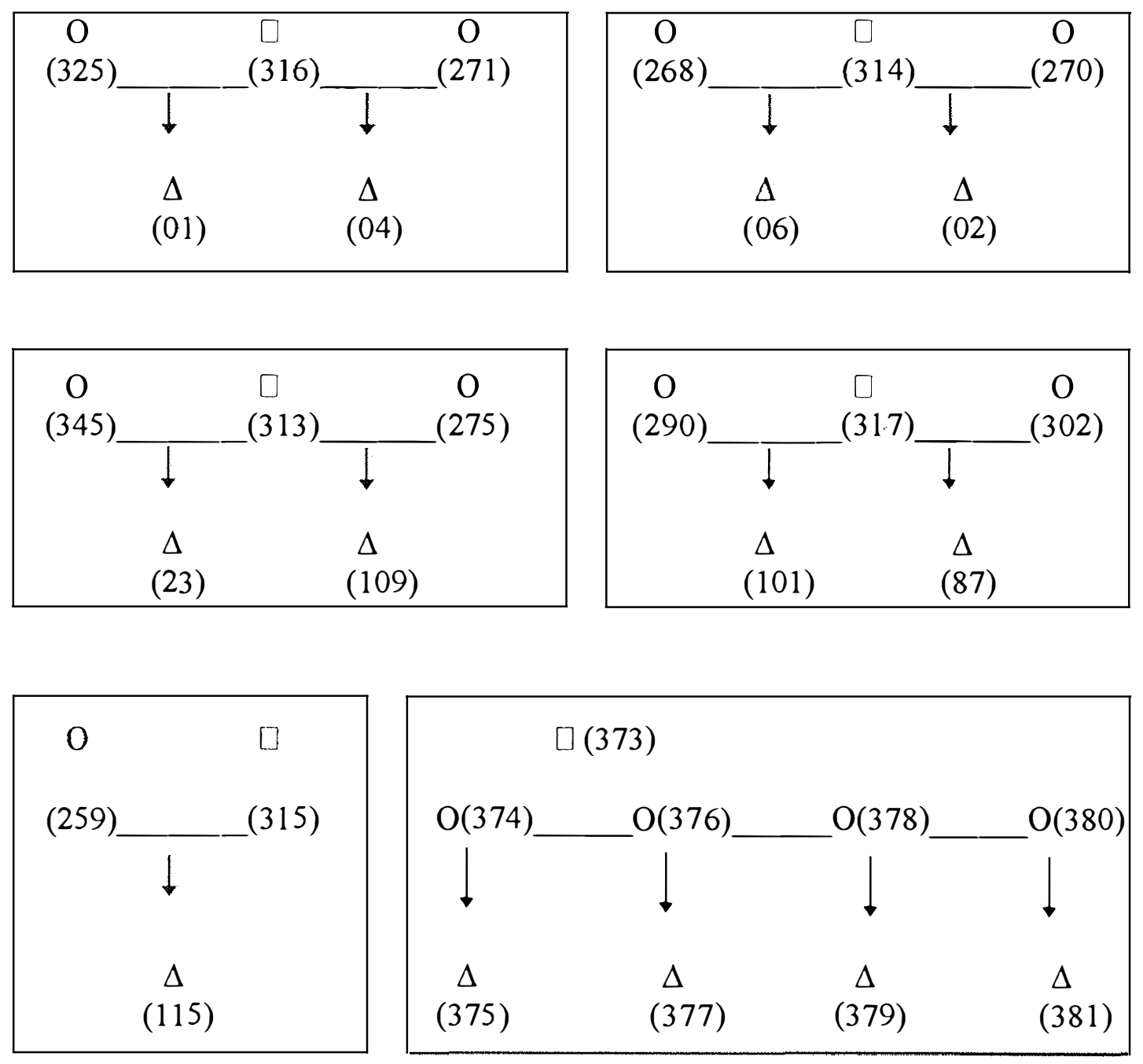

$\square=$ Touro

$\mathrm{O}=\mathrm{Vaca}$

$\Delta=$ Progênie

$(\mathrm{N})=$ Número do Animal

Figura 18. Famílias participantes do teste de paternidade. 
Tabela 10. Genótipos dos animais participantes do teste de paternidade.

\begin{tabular}{|c|c|c|c|c|c|c|c|}
\hline Marcador & $\mathrm{KpCs}$ & $\beta$-lact & $\mathrm{GH}$ & $I G F I$ & CSFM-50 & BM-1224 & INRA-006 \\
\hline \multicolumn{8}{|l|}{ Família } \\
\hline 316 & 12 & 22 & 11 & 24 & 48 & 24 & $-3-3$ \\
\hline 325 & 11 & 12 & 11 & 24 & 46 & 68 & 45 \\
\hline 01 & 12 & 22 & 11 & 22 & 48 & 46 & -34 \\
\hline 271 & 11 & 22 & 11 & 24 & 33 & 22 & 34 \\
\hline 04 & 12 & 22 & 11 & 24 & 38 & 22 & -33 \\
\hline 314 & 11 & 22 & 11 & 44 & 46 & 22 & 49 \\
\hline 268 & 11 & 12 & 11 & 44 & 66 & 46 & 45 \\
\hline 06 & 11 & 12 & 11 & 44 & 66 & 24 & 49 \\
\hline 270 & 12 & 12 & 11 & 44 & 88 & 24 & 35 \\
\hline 02 & 12 & 12 & 11 & 44 & 68 & 24 & 34 \\
\hline 313 & 11 & 22 & 11 & 44 & 67 & 111 & 44 \\
\hline 345 & 11 & 22 & 11 & 24 & 48 & 26 & -34 \\
\hline 23 & 11 & 22 & 11 & 44 & 47 & 12 & -34 \\
\hline 275 & 11 & 22 & 11 & 44 & 38 & 44 & -33 \\
\hline 109 & 11 & 22 & 11 & 44 & 37 & 411 & -34 \\
\hline 317 & 11 & 22 & 11 & 22 & 78 & 22 & 34 \\
\hline 290 & 11 & 12 & 11 & 44 & 46 & 24 & -34 \\
\hline 101 & 11 & 12 & 11 & 24 & 48 & 24 & 34 \\
\hline 302 & 11 & 11 & 11 & 44 & 48 & 16 & 34 \\
\hline 87 & 11 & 12 & 11 & 24 & 48 & 26 & 34 \\
\hline 315 & 11 & 12 & 11 & 44 & 66 & 22 & 34 \\
\hline 259 & 11 & 12 & 11 & 24 & 67 & 24 & 49 \\
\hline 115 & 11 & 12 & 11 & 24 & 67 & 22 & 44 \\
\hline 373 & 11 & 22 & 11 & 44 & $44^{*}$ & $46^{*}$ & $34^{*}$ \\
\hline 374 & 11 & 12 & 11 & 24 & $78^{*}$ & $88^{*}$ & $45^{*}$ \\
\hline 375 & 11 & 22 & 11 & 44 & $46^{*}$ & $22 *$ & $-33^{*}$ \\
\hline 376 & 11 & 11 & 11 & 24 & 68 & 22 & 34 \\
\hline 377 & 11 & 12 & 11 & 44 & 46 & 26 & 34 \\
\hline 378 & 11 & 11 & 11 & 44 & 68 & 22 & 34 \\
\hline 379 & 11 & 12 & 11 & 44 & 48 & 24 & 44 \\
\hline 380 & 11 & 22 & 11 & 44 & 46 & $22^{*}$ & -13 \\
\hline 381 & 11 & 22 & 11 & 44 & 46 & $46^{*}$ & 34 \\
\hline
\end{tabular}

*= exclusão de paternidade 
Tabela 11. Proporção de touros excluídos de paternidade considerando os genótipos da vaca e da progênie e frequêências gênicas na população e probabilidade de paternidade do touro considerado (PP).

\begin{tabular}{|c|c|c|c|c|c|c|c|c|}
\hline Marcador & KpCs & $\beta$-lact & $\mathrm{GH}$ & $I G F I$ & CSFM-50 & BM-1224 & INRA-006 & PP \\
\hline \multicolumn{9}{|l|}{ Família } \\
\hline 316 & \multirow[b]{2}{*}{0,8336} & \multirow{3}{*}{0,164} & \multirow{3}{*}{0} & \multirow{3}{*}{0,5446} & \multirow{3}{*}{0,4665} & \multirow{3}{*}{0,5213} & \multirow{3}{*}{0,6545} & \multirow{3}{*}{0,9944} \\
\hline 325 & & & & & & & & \\
\hline 01 & & & & & & & & \\
\hline $\begin{array}{c}271 \\
04\end{array}$ & 0,8336 & 0,164 & 0 & 0 & 0,4665 & 0,2916 & 0,6545 & 0,9818 \\
\hline 314 & \multirow[b]{2}{*}{0,0076} & \multirow[b]{2}{*}{0} & \multirow[b]{2}{*}{0} & \multirow[b]{2}{*}{0,0686} & \multirow[b]{2}{*}{0,5685} & \multirow[b]{2}{*}{0,2916} & \multirow[b]{2}{*}{0,7762} & \multirow[b]{2}{*}{0,9368} \\
\hline $\begin{array}{c}268 \\
06\end{array}$ & & & & & & & & \\
\hline $\begin{array}{c}270 \\
02\end{array}$ & 0 & 0 & 0 & 0,0686 & 0,5685 & 0,0688 & 0,3260 & 0,7478 \\
\hline 313 & & & & & & & & \\
\hline 345 & 0,0076 & 0,1640 & 0 & 0,5446 & 0,7208 & 0,9063 & 0,0485 & 0,9906 \\
\hline 23 & & & & & & & & \\
\hline 275 & 0,0076 & 0,1640 & 0 & 0,0686 & 0,7208 & 0,9913 & 0,3260 & 0,9987 \\
\hline 109 & & & & & & & & \\
\hline 317 & & & & & & & & \\
\hline 290 & 0,0076 & 0 & 0 & 0,5446 & 0,4665 & 0,0688 & 0,6545 & 0,9224 \\
\hline 101 & & & & & & & & \\
\hline $\begin{array}{c}302 \\
87\end{array}$ & 0,0076 & 0,1640 & 0 & 0,0686 & 0,1706 & 0,2916 & 0,1444 & 0,6115 \\
\hline 315 & & & & & & & & \\
\hline 259 & 0,0076 & 0 & 0 & 0 & 0,3636 & 0,2916 & 0,3260 & 0,6985 \\
\hline 115 & & & & & & & & \\
\hline 373 & & & & & & & & \\
\hline 376 & 0,0076 & 0,1640 & 0 & 0,0686 & 0,5329 & 0,7762 & 0,1444 & 0,9309 \\
\hline 377 & & & & & & & & \\
\hline 378 & 0,0076 & 0,1640 & 0 & 0,0686 & 0,5329 & 0,5213 & 0,3260 & 0,8823 \\
\hline 379 & & & & & & & & \\
\hline
\end{tabular}


As proporções médias de touros excluídos por marcador foram, 0,1571, 0,104, 0, 0,1859, 0,5071, 0,456 e 0,398 para os marcadores Kapa-caseína, $\beta$-lactoglobulina, Hormônio do Crescimento, IGF I, CSFM-50, BM-1224 e INRA-006 no Teste de Paternidade. Estes valores são relativamente próximos aos valores de probabilidade de exclusão (PE) obtidos $(0,08$, $0,2018,0,0,1747,0,5319,0,4691$ e 0,543$)$, principalmente para os microssatélites. Um número maior de famílias estudadas poderá aproximar ainda mais os resultados.

Os resultados do teste de paternidade apresentaram probabilidade de paternidade variando entre 0,6115 e 0,9987 , com média 0,8814 . Portanto, somente 3 famílias atingiram os 0,99 recomendados. Ainda assim esta freqüência de erro na identificação atingiu os $15 \%$ (3/13), concordante com o obtido em outros países (Ron et al., 1996). Se este valor for representativo para da raça Nelore evidencia-se a necessidade de um controle mais eficiente sobre os registros genealógicos de uma população em programa de Melhoramento Genético, devido ao efeito negativo na estimação do valor genético dos animais em controle.

O Teste de Paternidade poderia ser aplicado na avaliação de touros em fazendas que utilizam reprodutores múltiplos (Trovo et al. 1996), ou em um programa de avaliação de touros jovens, objetivando aprimorar a estimação do valor genético, realizando o teste em um número pré determinado de animais para se atingir a acurácia desejada.

A amostra considerada deverá ser ampliada para permitir uma amostragem adequada de diferentes linhagens de Nelore existentes. Esta amostragem permitiria melhorar a confiabilidade do teste de paternidade, uma vez que os animais seria testados considerando as frequeências alélicas da linhagem a qual forem pertencentes (Balding \& Nichols, 1995).

Outros marcadores microssatélite deverão ser avaliados e acrescentados ao teste de paternidade para se atingir a PE pretendida. Para alcançar os 0,99 seriam necessários 7 marcadores com PE 0,5 (0,9922), ou 5 marcadores com PE 0,6 (PEC 0,9898), ou 4 marcadores com PE $0,7(0,9919)$. Os valores de probabilidade de exclusão combinada foram estimados a partir da fórmula de Dodds et al. (1996). 
A utilização de outras técnicas de análise genética são necessárias para a viabilização comercial do teste de paternidade, como o de "PCR-multiplex" (Glowatski-Mullis et al., 1995, ou seja, amplificação simultânea de dois ou mais marcadores. Um "PCR-multiplex" poderia ser operado para três ou quatro marcadores, de modo que duas reações seriam suficientes para a realização do Teste de paternidade. Além do "PCR-multiplex", a eletroforese simultânea para todos os marcadores poderia ser realizada para marcadores pré-selecionados por não possuírem tamanhos semelhantes e, consequentemente, bandas sobrepostas e leitura realizada em um sequenciador automático. Estas alterações na metodologia permitiriam reduzir os custos de análise dos genótipos viabilizando economicamente o seu uso. 


\section{5- CONCLUSÕES}

As frequências encontradas para os locos Kapa-caseína e $\beta$ lactoglobulina são concordantes com os valores descritos na literatura, sugerindo que a amostra é representativa da raça Nelore. Além disto, considerando o fato da amostra ser relativamente pequena, não foi encontrado desequilíbrio de Hardy-Weinberg.

Os microssatélites CSFM-50, BM-1224 e o INRA-006 apresentaram polimorfismo satisfatório, e conseqüêntemente Probabilidade de Exclusão (PE) adequados para se proceder um Teste de Paternidade. $\mathrm{O}$ mesmo não se pode afirmar para o marcadores RFLP, Kapa-caseína, Hormônio do Crescimento e $\beta$ lactoglobulina e do microssatélite $I G F \mathrm{I}$.

A PEC (Probabilidade de Exclusão Combinada) 0,9089 não atingiu o valor $(0,99)$ citado como adequado ao teste de paternidade. Portanto outros marcadores microssatélite devem ser adicionados para se atingir a PE pretendida.

Além de microssatélites mais polimórficos outras técnicas de análise genética são necessárias para aumentar a rapidez do teste e diminuir os custos relativos a genotipagem dos animais, viabilizando o uso comercial de teste de paternidade

A amostragem deverá ser ampliada para permitir uma caracterização das diferentes linhagens existentes na raça e melhorar a confiabilidade do teste de paternidade. Uma vez que os animais seriam testados de acordo com as freqüências alélicas da linhagem a que pertencerem.

O erro de identificação $15 \%$ obtido neste trabalho justifica o uso do teste de paternidade em programas de melhoramento genético. $O$ teste de paternidade deveria ser aplicado em varias situações práticas: (1) - em uma porcentagem dos animais registrados a cada ano na associação, para verificar a validade e consistência 
das informações fornecidas pelos produtores; (2)- nos programas de seleção que utilizam da técnica dos reprodutores múltiplos, sempre que os custos do teste forem inferiores aos beneficios atuais e futuros; (3)- nos programas de avaliação de touros jovens, objetivando aprimorar a predição do valor genético. 


\section{REFERÊNCIAS BIBLIOGRÁFICAS}

AMIGUES, Y.; BRATHWAITE; B.; LEPIN, L. et al. Use of microsatellites as an alternative to blood typing in goat parentage control. In: CONFERENCE OF THE INTERNATIONAL SOCIETY FOR ANIMAL GENETICS, 24., Prague, 1994. Proceedings. Animal Genetics, v. 25, p. 27, dec.1994, Suplement 2.

ANDERSSON, L. The role of MHC polymorphism in disease/parasite resistance. In: WORLD CONGRESS ON GENETICS APPLIED TO LIVESTOCK PRODUCTION, 5., Guelph, 1994. Proceedings. Guelph: University of Guelph, Dept ${ }^{\circ}$ Animal and Poultry Science, 1994. v. 21, p.177- 182.

ARNHEIN, N.; LI, H.; CUI, X. PCR analysis of DNA sequence in single cells: single sperm typing and genetic disease diagnosis. Genomics, v. 8, p. 415- 419, 1990.

ARROYO, E.; GARCÍA-SÁNCHES, F.; GÓMES-REINO, F. et al. Prenatal exclusion of paternity by PCR-RFLP analysis of VNTR. Journal of Forensic Sciences, v.39: p. 566-572, 1994.

BAKER, C. M. A.; MANWELL, C. Eletrophoretic variation of erythrcyte enzimes of domesticated mammals. In: AGAR, N. S.; BOARD, P. G. (Ed). Red blood cells of domesticated mammals. Amsterdan: Elsevier, 1983. p. 366-412.

BALDING, D. J.; NICHOLS, R. A. A method for quantifying differentiation between populations at multi-allelic loci and its implications for investigating identity and paternity. Genética, v. 96, p. 3-12, 1995.

BARBOSA, P. F. Bases genéticas para a divergência das espécies de bovinos. Ecossistema, v. 13, p. 1-15, 1988.

BARENDSE, W.; ARMITAGE, S. M.; KOSSAREK, L. M. et al. A genetic linkage map of the bovine genome. Nature Genetics, v. 6, p. 227- 235, 1994.

BASSAN, B. J.; ANOLLÉS, G. C.; GRESSHOFF, P. M. Fast and sensitive silver staining of DNA in polyacrilamide gels. Analytical Bioquemistry, v. 196, p. 80-83, 1991.

BECKMANN, J. S.; SOLLER, M. Toward a unified approach to genetic mapping of eukarotes based on sequence tagged microsatellites sites. Biotechnology, v. 8, p. 930$932,1990$.

BEECHINOR, J.G.; KELLY, E.P. Errors of identification amongst cattle presented of some bulls used in the artificial insemination service in Ireland. Irish Veterinary Journal,. v. 41, p. 348, 1987. 
BEEVER, J. E.; GEORGE, P. D.; FERNANDO, R. L. et al. Associations between genetic markers and growth and carcass traits in a paternal half-sig family of Angus cattle. Journal of Animal Science, v. 68, p. 337-344, 1990.

BELGUELMAN, B. Genética médica-dinâmica dos genes nas populações e nas famílias. Sâo Pulo: EDAR. 1977. 389p.

BELL, K. The blood group of domesticated Mammals. In: AGAR, N. S.; BOARD, P. G. (Ed). Red blood cells of domesticated mammals. Amsterdan: Elsevier, 1983. p. 133- 163 .

BENSON, D. A.; BOGUSKI, M.; LIPMAN, D. J. et al. GenBank. Nucleic Acids Research, v. 24, n. 1, p. 1-5, 1996.

BERRYERE, T. G.; MUGGLI-COCKETT, N.; ROBBINS, J. W. et al. Molecular studies of DRB relative to Staphylococcus aureus mastitis. In: WORLD CONGRESS ON GENETICS APPLIED TO LIVESTOCK PRODUCTION, 5., Guelph, 1994. Proceedings. Guelph: University of Guelph, Dept ${ }^{0}$ Animal and Poultry Science, 1994. v. 21, p. 187- 190 .

BINDON, B.M.; PIPER, L.R. Boorola (F) gene: major gene affecting ovine ovarian function. In: EVANS, J. W.; HOLLAENDER, A. (Ed): Genetic engeneering of animals: an agriculture perspective. New York: Plenum Press, 1986. p. 678-693.

BINK, M. C. A. M. \& ARENDONK, J. A. M. van Marker-assisted prediction of breeding values in dairy cattle populations. In: WORLD CONGRESS ON GENETICS APPLIED TO LIVESTOCK PRODUCTION, 5., Guelph, 1994. Proceedings. Guelph: University of Guelph, Dept ${ }^{\circ}$ Animal and Poultry Science, 1994. v. 21, p.233236.

BISHOP, M. D.; KAPPES, S. M.; KEELE, J. W. et al. A genetic linkage map for cattle. Genetics, v. 136, p. 619-639, 1994.

BOTSTEIN, D.; WHITE, R. L.; SKOLNICK, M. et al. Construction of a genetic linkage map in man using Restriction Fragment Length Polymorphism. American Journal of Human Genetics, v. 32, p. 314-331, 1980.

BOVENHUIS, H; ARENDONK, J. A. M.; KORVER, S. Associations between milk protein polymorphism and production traits. Journal of Dairy Science, v. 75, p. 2549-2559, 1992.

BOWCOCK, A.M.; RUIZ-LINARES, A.; TOMFOHRDE, J. et al. High resolution of human evolutionary trees with polymorphic microsatellites. Nature, v. 368, p. 455457, 1994. 
BRASIL. Ministério da Agricultura. Regulamento do serviço de registro genealógico das raças zebuínas. Uberaba: $\mathrm{ABCZ}, 1994.78 \mathrm{p}$.

CAETANO-ANÓlleS, G.; BASSAN, B. J.; GRESSOFF, P. M. High-resolution amplification fingerprinting (DAF): detection and amplification fragment lengh polymorphisms in soybean using very short arbitrary oligonucleotide primers. Soybean Genetics Newsletter, v. 18, p. 279-283, 1991.

CAMPOS, L. T. Seleção de gado de corte com o PROMEBO. In: SIMPÓSIO NACIONAL DE MELHORAMENTO ANIMAL, 1., Ribeirão Preto, 1996. Anais. Viçosa: Sociedade Brasileira de Melhoramento Animal, 1996. p.185- 189.

CARDOSO, E. P. A seleção do Nelore pela MANAH. In: SIMPÓSIO NACIONAL DE MELHORAMENTO ANIMAL, 1., Ribeirão Preto, 1996. Anais. Viçosa: Sociedade Brasileira de Melhoramento Animal, 1996. p. 160- 163.

CAVALIER-SMITH, T. Kingdon protozoa and its 18 phyla. Microbiology Reviews, v. 57, p. 953-994, 1993.

CAVALLI-SFORZA, L. L.; EDWARDS, A. W. F. Phylogenetic analysis: models and estimation procedures. Evolution, v. 21, p. 550-570, 1967.

CEPICA, S.; WOLF, J.; HOJNÝ, J. et al. Relations between genetic distance of parental pig breeds and heterozygosity of their $F_{1}$ crosses measured by genetic markers. Animal Genetics, v. 26, p. 135- 140, 1995.

CHAKRABORTY, R.; SHAW, M.; SCHULL, W. J. Exclusion of paternity: the current state of the art. American Journal of Human Genetics, v. 26, p. 477-488, 1974.

CIAMPOLINI, R.; MOAZAMI-GODARZI, K.; VAIMAN, D. et al. Individual multilocus genotypes using microsatellite polymorphisms to permite the analysis of the genetic variability within and between Italian beef cattle breeds. Journal of Animal Science, v. 73, p. 3259-3268, 1995.

COMINCINI, S.; SIRONI, M.; BANDI, C. et al. RAPD analysis of sistematic relationships among the Cervidae. Heredity, v. 76, p. 215-221, 1996.

COUTINHO, L. L.; REGITANO, L. C. A. O uso de marcadores moleculares na industria animal. In: CONGRESSO BRASILEIRO DE REPRODUÇÃO ANIMAL, 11. Belo horizonte, 1995. Trabalho apresentado. Belo Horizonte: Colégio Brasileiro de Reprodução Animal, 1995. p 195-205. 
COWAN, C. M.; DENTINE, M. R.; AX, R. L. et al. Structural variation around prolactin gene linked to quantitative traits in elite Hostein sire family. Theoretical and Applied Genetics, v. 79, p. 566-582, 1990.

CRAWFORD, A. M.; TATE, M. L.; MCEWAN, M. L. et al. How reliable are sheep pedigrees? Proceedings of the New Zeland Society of Animal Production, v. 53, p. 363-366, 1993.

CROTHERS, D. M.; HARAN, T. E.; NADEAU, J. G. Intrinsically bent DNA. Journal of Biological Chemistry, v. 265, p 7093- 7096, 1990.

CUNNINGHAN, P. LOFTUS, R.T.; MCHUGH, D.E. et al. Molecular evolution of African, European and Asian cattle. In: WORLD CONGRESS ON GENETICS APPLIED TO LIVESTOCK PRODUCTION, 5., Guelph, 1994. Proceedings. Guelph: University of Guelph, Dept ${ }^{\circ}$ Animal and Poultry Science, 1994. v. 21, p.8689.

DA, Y., LEWIN, H. A. Linkage informtion content and efficiency of full-sib and half-sib designs for gene mapping. Theoretical and Applied Genetics, v. 90, p. 699-706, 1995.

DEL LAMA, S. N. Caracterização genética das raças zebuínas criadas no Brasil através de polimorfismos protéicos e grupos sanguíneos. Ribeirão Preto, 1991. 207p. Tese (Doutorado) - Faculdade de Medicina de Ribeirão Preto, Universidade de São Paulo.

DEL LAMA, S. N.; ZAGO, M. A. Identification of the $\kappa$-casein and $\beta$-lactoglobulin genotypes in Brasilian Bos indicus and Bubalus bubalis populations. Brasilian Journal of Genetics, v. 19, p. 73-77, 1996.

DENNIS, J.A.; HEALY, P.J.; BEAUDET, A.L. et al. Molecular definition of bovine arginiosuccinate synthetase deficiency. Proceedings of the National Academy of Science, v. 86, p. 7947-7951, 1989.

DIAS, F. M. G. N. O programa PAINT/ Lagoa da Serra. In: SIMPÓSIO NACIONAL DE MELHORAMENTO ANIMAL, 1., Ribeirão Preto, 1996. Anais. Viçosa: Sociedade Brasileira de Melhoramento Animal, 1996. p. 190- 193.

DODDS, K. G.; TATE, M. L.; MCEWAN, J. C. et al. Exclusion probabilities for pedigree testing farm animals. Theoretical and Applied Genetics, v. 92, p. 966-975, 1996.

DOSTÁL, J.; STRATIL, A. Polymorphic markers as tolls for paterity control in dogs. In: CONFERENCE OF THE INTERNATIONAL SOCIETY FOR ANIMAL GENETICS, 24., Prague, 1994. Proceedings. Animal Genetics, v. 25, p. 13, dec.1994, Suplement 2. 
EGGEN, A.; FRIES, R. An integrated cytogenetic and meiotic map of the bovine genome. Animal Genetics, v. 26, p. 215-236, 1995.

EGGEN, A.; BAHRI-DARWICH, I.; MERCIER, D. et al. Assignment of bovine synteny group U2 to chromosome 9. Animal Genetics, v. 25, p. 183-185, 1994.

EMERY, A. E. H.; MALCON, S. An introduction to recombinant DNA in medicine. Chichester: John Willey, 1995. 205p.

EPSTEIN, $\mathrm{H}$. The origen of the domesticated animals of Africa. New York: African Publ., 1971. 1, p. 256.

EPSTEIN H.; MASON, I. L. Cattle. In: MASON, I. L. (Ed) Evolution of domesticated animals. London: Longman, 1984. p 6- 27.

ERLICH, H. A.; GELFAND, D. H.; SAIKI, R. K. Specific DNA amplification. Nature, V. 331, p. 461-462, 1988.

EUCLIDES FILHO, K. E. Resultados de cruzamentos em gado de corte no CNPGC. In: SIMPÓSIO NACIONAL DE MELHORAMENTO ANIMAL, 1., Ribeirão Preto, 1996. Anais. Viçosa: Sociedade Brasileira de Melhoramento Animal, 1996. p. 240242.

FERREIRA, M. E.; GRATTAPALIA, D. Introdução ao uso de marcadores RAPD e RFLP em análise genética. Brasília: EMBRAPA-CENARGEN, 1995, 220p.

FLORES, R.; RICHARDSON, T. Genetic engineering o the caseins to modify the behavior of milk during processing: a review. Journal of Dairy Science, v. 71, p. 2640-2654, 1988.

FRIES, R. Mapping the bovine genome: methodological aspects and strategy. Animal Genetics, v. 24, p. 111-116, 1993.

FRIES R.; EGGEN, A.; WOMACK, J.E. The bovine genome map. Mammalian Genome, v. 4, p. 405-428, 1993.

FRIES R.; EGGEN, A.; STRANZINGER, G. The bovine genome contains polymorphic microsatellites. Genomics, v. 8, p. 403-406, 1990

FRIES, R.; BECKMANN, J. S.; GEORGES, M. et al. The bovine gene map. Animal Genetics, v. 20, p.3, 1989. 
GELDERMANN, H.; PIEPER, U.; WEBER, W. E. Effect of misidentification on the estimation of breeding value and heritability in cattle. Journal of Animal Science, v. 63, p. 1759- 1768, 1986.

GEORGES, M.; MASSEY, J. M. Velogenetics, or the synergistic use of marker assisted selection and germ-line manipulation. Theriogenology, v. 35, p. 151-159, 1991.

GEORGES, M.; DIETZ, A. B.; MISHRA, A. et al. Microsatellite mapping of the gene causing weaver disease in cattle will allow the study of an associated quantitative triat locus. Proceedings of the National Academy of Science, v. 90, p. 1058-1062, 1993a.

GEORGES, M.; DRINKWATER, R.; KING, T. et al. Microsatellite mapping of the gene affecting horn development in Bos taurus. Nature Genetics, v. 4, p. 206-208, 1993 b.

GEORGES, M.; LATHOROP, M.; BOUQUET, Y. et al. Linkage relationships among 20 genetics markers in cattle. Evidence for linkage between two pairs of blood group systems: B-Z and S-F/V respectively. Animal Genetics, v. 21, p. 95-105, 1990.

GEORGES, M.; LEQUARRE, A. S.; CASTELLI, M. et al. DNA fingerprinting in domestical animals using four diferent minisatellite probes. Cytogenetics and Cell Genetics, v. 47, p. 127-131, 1988.

GEORGES, M.; NIELSEN, D.; MACKINNON, M. et al. Mapping quantitative trait loci controling milk production in dairy cattle by exploiting progeny testing. Genetics, v. 132, n. 2, p. 907-920, 1994.

GJERTSON, D.W.; MORRIS, J.W. Assessing probability of paternity and the product rule in the DNA systems. Genetica, v. 96, p. 89-98, 1995.

GJERTSON, D. W.; MICKEY, M. R.; HOPFIELD, J. et al. Calculation of probability of paternity using DNA sequences. American Journal of Human Genetics, v. 43, p. 860-869, 1988.

GLOWATSKI-MULliS, M. L.; GAILlARD, C.; WIGGER, G. et al. Microsatellitebased parentage control. Animal Genetics, v. 26, p. 7-12, 1995.

GRAML, R.; OHMAYER, G.; PIRCHNER. et al. Biomechanical polymorphism in Egyptian Baladi cattle and their relationship with other breeds. Animal Genetics, v. 17, p. 61-76, 1986. 
GREEN, R. D.; COCKETT, N. E.; MLLER, M. F. et al. Characterization of Taq I polymorphisms in the bovine calpastatin gene. In: WORLD CONGRESS ON GENETICS APPLIED TO LIVESTOCK PRODUCTION, 5., Guelph, 1994. Proceedings. Guelph: University of Guelph, Dept ${ }^{\circ}$ Animal and Poultry Science, 1994. v. 21, p.450- 453.

GRIGSON, G. The craniology and relationships of four species of Bos. Bos indicus $L$. Journal of Archaeological Science, v. 7, p. 3-32, 1980.

GÚERIN, G.; EGGEN., A.; VAIMAN, D. et al. Further characterization of somatic cell hybrid panel: ten new assigments to the bovine. Animal Genetics, v. 25, p. 31-35, 1994.

HABERFELD A.; DUNNINGTON, E. A.; SIEGEL, P. B. et al. Heterosis and DNA fingerprinting in chickens. Poultry Science, v. 75, p. 951- 953, 1996.

HAFEZ, I. S. E. Reprodução animal. 4. ed. São Paulo: Manole, 1988. 720 p.

HAMADA, H.; PETRINO, M.; KAKUNAGA, T. A novel repeated element with ZDNA. Proceedings of the National Academy of Science, v. 79, v. 6465-6469, 1982.

HAMMOND, H. A.; REDMAN, J. B.; CASKEY, C. T. In utero paternity testing following alleged sexual assault. A comparison of DNA-based methods. Journal of the American Medical Association, v. 273, p. 1774-1777, 1995.

HANSET, R.; MICHAUX, C. On the genetic determinism of muscular hypertophy in the Belgian White and Blue cattle breed. Il. Population data. Genetics Selection and Evolution, v. 17, n. 3, p. 269-386, 1985.

HART, G. L.; BASTIANSEN, J.; DENTINE, M. R. et al. Detection of a four-alele single strand conformation polymorphism (SSCP) in the bovine prolactin gene. Animal Genetics, v. 24, p. 149, 1993.

HEALY, P. J.; DENNIS, J. A. Inherited diseases in beef cattle in Australia. In: WORLD CONGRESS ON GENETICS APPLIED TO LIVESTOCK PRODUCTION, 5., Guelph, 1994. Proceedings. Guelph: University of Guelph, Dept ${ }^{\circ}$ Animal and Poultry Science, 1994. v. 21, p. 185- 186.

HENDERSON, C. R. Use of an average numerator relationship matrix for multiple sire joining. Journal of Animal Science, v. 66, p. 1614-1621, 1988.

HILLEL, J.; SCHAAP, T.; HABERFIELD, A. et al. DNA fingerprints applied to genome introgression in breeding programes. Genetics, v. 124, p. 783- 789, 1990. 
HOESCHELE, I.; MEINERT, T.R. Association of genetic defects with yield and type traits: the weaver locus effect on yield. Journal of Dairy Science, v. 73, p. 2503$2515,1990$.

HOHENHÖRST, J.; FRIES, R.; VÖGELI. E. et al. Use of microsatellites for parentage control in pigs. In: CONFERENCE OF THE INTERNATIONAL SOCIETY FOR ANIMAL GENETICS, 24., Prague, 1994. Proceedings. Animal Genetics, v. 25, p. 33, dec.1994, Suplement 2.

HOJ, S.; FREDHOLM, M.; LARSEN, N. J. et al. Growth hormone gene polymorphism associated with selection for milk fat production in lines of cattle. Animal Science, v. 24, p. 91-96, 1993.

HOLMES, N. G. Microsatellite markers and the analysis of genetic disease. British Veterinary Journal, v. 150, p. 411-421, 1994.

HUGHES, A. L.; NEI, M. Pattern of nucleotide substitution at major histocompatibility complex class I loci reveals overdominant selection. Nature, v. 335, p. 167-170, 1988.

HUGHES, A. L.; NEI, M. Nucleotide substitution at major histocompatibility complex class II loci: evidence for overdominance selection. Proceedings of the National Academy of Science, v. 86, p. 958-962, 1989.

INNIS, M. A.; GELFAND, D. H.; SNINSKY, J. J. et al. PCR protocols- a guide to methods and applications. San Diego: Academic Press, 1989. p. 482.

JAMIELSON, A. The effectiveness of using co-dominant polymorphic allelic series for (1) checking pedigrees and (2) distinguishing full-sib pair members. Animal Genetics, v. 25 , p. $37-44,1994$. Suplement 1.

JAMIELSON, A. The genetics of transferrins in cattle. Heredity, v. 20, p. 419-441, 1965.

JEFFREYS, A. J.; TURNER, M.; DEBENHAN, P. The efficiency of multilocus DNA fingerpriting probes for individualization and establishment of family relationships, determinaed from extensive casework. Americam Journal of Human Genetics, v. 48, p. 824-840, 1991.

JEFFREYS, A. J.; WILSON, V.; THEIN S. L. Hypervariable minisatellite regions in the human DNA. Nature, v. 314, p. 67-73, 1985 a.

JEFFREYS A. J.; WILSON, V.; THEIN, S. L. Individual specific "fingerprints" of human DNA. Nature, v. 316 , p. $76-79,1985$ b. 
JOLLĖS, P.; JOLLÈS, J. What's new in lysozyme research? Always a model sistem, today as yesterday. Molecular and Cellular Bioquemistry, v. 63, p. 165-189, 1984.

JOSAKIAN, L. A. ABCZ- Novas direções do programa de melhoramento genëtico de zebuïnos. In: SIMPÓSIO NACIONAL DE MELHORAMENTO ANIMAL, 1., Ribeirão Preto, 1996. Anais. Viçosa: Sociedade Brasileira de Melhoramento Animal, 1996. p. 199- 203.

KAUFMAN, J.; SKJODT, K.; SOLOMONSEN, A. et al. MHC like molecules in some nonmammalian vertebrates can be detected by some cross-reactive xenoantisera. The Journal of Immunology, v. 144, p. 2258-2272, 1992.

KEHRLI, M. E. J.; ACKERMANN, M. R.; SHUSTER, D. E. et al. Bovine leukocyte adhesion deficiency. In: WORLD CONGRESS ON GENETICS APPLIED TO LIVESTOCK PRODUCTION, 5., Guelph, 1994. Proceedings. Guelph: University of Guelph, Dept ${ }^{\circ}$ Animal and Poultry Science, 1994. v. 21, p.157- 164.

KELLY, T. J.; SMITH, H. O. A restriction enzime from Haemophilus influenzae. IIbase sequence of the recognition site. Journal of Molecular Biology, v. 51, p. 393409, 1970.

KEMENES, P. A. A quantificação das frequêencias dos alelos " $A$ " e "B" dos genes Kappa-caseína e $\beta$-lactoglobulina em algumas raças bovinas. Piracicaba, 1996. 85p. Dissertação (Mestrado) - Escola Superior de Agricultura "Luiz de Queiroz", Universidade de São Paulo.

KEMP, S. J.; HISHIDA, O.; WAMBUGU, J. et al. A panel of polymorphic bovine, ovine and caprine microsatellite markers. Animal Genetics, v. 26, p. 299-306, 1995.

KIEFFER, N. M.; CARTWRIGTH, T. C. Sex chromosome polymorphism in domestic cattle. Journal of Heredity, v. 59, p. 35-37, 1968.

KINGHORN, B. P.; KENNEDY, B. W.; SMITH, C. A method of screening for genes of major effect. Genetics, v. 134, p. 351-360, 1993.

KIRKPATRICK, B. W. Diallelic single-strand conformation polymorphism in the bovine inuslin-like growth factor- 1 third intron. Animal Genetics, v. 24, p. 144, 1993.

KIRKPATRICK, B. W.; HART, G. L. Conformation polymorphisms and targeted marker development. Animal Genetics, v. 25, p. 77-82, 1994.

KIRKPATRICK, B. W; HUFF, B. M.; CASAS-CARRILO, E. Double-strand DNA conformation polymorphism as a source of highly polymorphic genetic markers. Animal Genetics, v. 24, p. 155-161, 1993 
KUMAR, S.; RZHETSKY, A. Evolutionary relationships of eukaryotic kingdons. Journal of Molecular Evolution, v. 42, p. 183-193, 1996.

LAGSIEL, A.; LIPKIN, E.; SOLLER, M. Association between SSCP haplotypes at the bovine growth hormone gene and milk protein percentage. Genetics, v. 142, p. 945951, 1996.

LANDER, E. S.; BOTSTEIN, D. Mapping mendelian factors underlying quantitative traits using RFLP linkage maps. Genetics, v. 121, p. 185-199, 1989.

LITT, M; LUTY, J. A. A hypervariable microsatellite revealed by "in vitro" amplification of a dinucleotide within the cardiac muscle actin gene. American Jounal of Human Genetics, v. 44, p. 397-401, 1989.

LIU, Q.; SOMMER, S. S. Restriction endonuclease fingerprinting (REF): A sensitive method for screening mutations in long continuous segments of DNA. Biotechniques, v. 18 , p. $470-477,1995$.

LÔBO, R. B. Programa de melhoramento genético da raça Nelore: parceria Universidade- Criador. In: SIMPÓSIO NACIONAL DE MELHORAMENTO ANIMAL, 1., Ribeirão Preto, 1996. Anais. Viçosa: Sociedade Brasileira de Melhoramento Animal, 1996. p. 176- 184.

LOFTUS, R.T.; MACHUGH, D.E.; BRADLEY, D. G. et al. Evidence for two independent domestications of cattle. Proceedings of the National Academy of Science, v. 91, p. 2757-2761, 1994a.

LOFTUS, R. T.; MACHUGH, D.E.; NGERE, L. O. et al. Mitochondrial genetic variation in European, African and Indian cattle populations. Animal Genetics, v. 25: p. $265-271,1994 b$.

LUCY, M. C.; HAUSER, S. D.; EPPARD, P. J. et al. Variants os somatotropin in cattle: gene frequences in major dayri breeds and associated milk production. Domesticated Animals Endocrinology, v. 10, p. 325-333, 1993.

LUSH, I. E. The biochemical genetics of vertrebrates except man: Frontiers of Biology. Amsterdan: North Holland. 1966, v. 3, 119p.

LUTY, J. A.; GUO, Z.; WILLARD H. F. et al. Five polynorphic microsatellite VNTRs on the human X chrmossome. American Journal of Human Genetics, v. 46, p. 776, 1990.

MACHUGH, D. P.; LOFTUS, R. T.; BRADLEY, D. G. et al. Microsatellite DNA variation within and among european cattle breeds. Proceedings of the Royal Society of London, v. 256, p. 25-31, 1994. 
MANWELL, C.; BAKER, C. M. A. Chemical classification of cattle 2. Phylogenetic tree and specific status of zebu. Animal Blood Groups and Biochemical Genetics, v. 11, p. $151-162,1980$.

MARKET, C. L.; MOLLER, F. Multiple forms of enzimes: Tissue, ontogenetic, and species-specific patterns. Proceedings of the National Academy of Science, v. 45, p. 753-763, 1959.

MASSEY, J.M.; GEORGES, M. Genmark's approach to marker assisted selection. Animal Biotechnology, v. 3, n. 1, p. 95-110, 1992.

MEDJUGORAC, I.; KUSTERMANN, W.; LAZAR, P. et al. Marker-derived phylogeny of European cattle supports demic expansion of agriculture. Animal Genetics, v. 25, p. 19-27, 1994. Suplement 1.

MEDRANO, J. F.; CORDOBA, E. A. Genotyping of bovine kappa-casein loci following DNA sequence amplification. Biotechnology, v. 8, p. 144-146, 1990a.

MEDRANO, J. F.; CORDOBA, E. A. Polymerase chain reaction amplification of bovine $\beta$-lactoglobulin genomics sequences and identificatoin of genetics variants by RFLP analysis. Animal Biotechnology, v. 1, p. 73-77, 1990 b.

MEJDELL, C. M.; LIE, O.; SOLBU, H. et al. Association of major histocompatibility complex antigens (BOLA-A) with AI bull progeny test results for mastitis, Ketosis and fertility in Norwegian cattle. Animal Genetics, v. 25, p. 99-104, 1994.

MIESFELD, R.; KRYSTAL, M; ARNHEIM, N. A member of new repeated sequence family wich is conserved throughout eucaryotic evolution is found between the human $\delta$ - and $\beta$-globulin genes. Nucleic Acids Research, v. 9, p. 5931, 1981.

MODI, W. S.; GALLAGHER, D. S.; WOMACK, J. E. Evolurionary histories f highly repeated DNA families mong the Artiodactyla (Mammalia). Journal of Molecular Evolution, v. 42, p. 337-349, 1996.

MOODY, D. E.; POMP, D.; NEWMAN, S. et al. Characterization of DNA polymorphisms in three populatoins of Herefrd cattle and their associations with growth and maternal EPD in line 1 Herefords. Journal of Animal Science, v. 74, p. 1784-1793, 1996.

MOORE, S. S.; BYRNE, K.; BERGER, K. T. et al., Characterization of 65 bovine microsatellite. Mammalian Genome, v. 5, p. 84-90, 1994. 
MOORE, S. S.; SARGEANT, L. L.; KING, T. J. et al. The conservation of dinucleotide microsatellites among mammalian genomes allows the use of heterologous PCR primer pairs in closely related species. Genomics, v. 10, p. 654-660, 1991.

MULLIS, K. B. The unusual origin of the polimerase chain reaction. Scientific American, v. 262, p. 6-42, 1990.

NAIK, S. N. Origen and domestication of the zebu cattle (Bos indicus). Journal of Human Evolution, v. 7, p. 23-30, 1978.

NAKAMURA, Y.; LEPPERT, M.; O'CONNEL, P. et al. Variable number of tanden repeat (VNTR) markers for human gene mapping. Science, v. 235, p. 1616-1622, 1987.

NEI, M. Genetic distances between populations. American Naturalist, v. 106, p. 283$292,1972$.

NIKOH, N.; HAYASE, N.; IWABE, N. et al. Phylogenetic relationships of Kingdons Animalia, Plantae and Fungi as inferred fron 23 different protein species. Molecular Biology and Evolution, v. 11, p. 762-768, 1994.

NOTT, C. F. G.; ROLLINS, W. Effect of the mh gene for muscular hypertrophy on birth weigth and growth to one year of age in beef cattle. Growth, v. 43, p. 221, 1979.

NOTTER, A. S. M. Genetic improvment of fertility using correlated traits and molecular markers. In: WORLD CONGRESS ON GENETICS APPLIED TO LIVESTOCK PRODUCTION, 5., Guelph, 1994. Proceedings. Guelph: University of Guelph, Dept ${ }^{\circ}$ Animal and Poultry Science, 1994. v. 18, p. 177- 182.

NOWAK, R. M.; PARADISO, J. L. Walker's mammals of the world. Baltimore: Johns Hopkins University. Press, 1983. p. 1232-1255.

O'BRIEN, S.J.; GRAVES, J. A. M. Report of the committee on comparative gene mapping. Cytogenetics and Cell Genetics, v. 58, p. 1124-1151, 1991

OLERUP, O.; ZETTERQUIST, H. HLA-DR typing by PCR amplification with sequence-specific primers (PCR-SSP) in 2 hours: An alternative to serological DR typing in clinical practice including donor-recipient matching in cadaveric transplantation. Tissue Antigens, v. 39, p. 225-235, 1992.

OLSAKER, I.; MEJDELL, C. M.; SORENSEN, A. et al. High lysozyme activity in a Norwegian bovine family co-segregates with a restriction fragment length polymorphism. Animal Genetics, v. 24, p. 421-425, 1993. 
ORITA, M.; SUSUKI, Y.; SEKIYA, T. et al. Rapid and sensitive detection of points of mutations and DNA polymorphisms using the polymerase chain reaction. Genomics, v. 5, p. 874-879, 1989.

PENA, S. D. J.; CHAKRABORTY, R. Paternity in the DNA era. Trends In Genetics, v. 6, p. 204-209, 1994.

PÉPIN, L.; AMIGUES, Y.; LÉPINGLE, A. et al. Sequence conservation of microsatellite between Bos taurus (cattle), Capra hircus (cabra) and related species. Examples of use in parentage testing and and phylogy analysis. Heredity, v. 74, p. 53-61, 1995.

PIPER, L.R.; BINDON, B.M. The genetics and endocrinology of the Booroola sheep F gene. In: WEIR, B.S.; EISEN, E.J.; GOODMAN M.M. et al. International Conference on Quantitative Genetics Sinauer Associates, Inc., Sunderland, MA, 1988, p270.

PÖTER, V. J. Programa Delta- G. In: SIMPÓSIO NACIONAL DE MELHORAMENTO ANIMAL, 1., Ribeirão Preto, 1996. Anais. Viçosa: Sociedade Brasileira de Melhoramento Animal, 1996. p. 167- 171.

PURGLY, J. Geneplan- Programa de seleção genética do Nelore CFM. In: SIMPÓSIO NACIONAL DE MELHORAMENTO ANIMAL, 1., Ribeirão Preto, 1996. Anais. Viçosa: Sociedade Brasileira de Melhoramento Animal, 1996. p. 164- 166.

QUASS, R. L.; POLLACK, E. J. Mixed model methodology for farm and ranch beef cattle testing programs. Journal of Animal Science, v. 51, p. 1277-1287, 1980.

RAMPILLI, M; CAROLI, A.; BOLLA, P. et al. Relazioni tra gnotip lattoproteici, composizione caseinica e attitudine alla coagulazione del latte nel corso della lattazione. Scienza e Tecnica Lattiero-Casearia, v. 39, p. 262-279, 1988.

RASMUNSEN, B. A.; CHRISTIAN, L. L. H blood types in pigs as predictors of stress suscetibility. Science, v. 191, p. 947, 1976.

RAZOOK, A. G.; FIGUEIREDO, L. A.; NETO, L. M. B. et al. O programa de seleção da Estação Experimental de Zootecnia de Sertãozinhio: resultados em 14 anos de progênies. In: SIMPÓSIO NACIONAL DE MELHORAMENTO ANIMAL, 1., Ribeirão Preto, 1996. Anais. Viçosa: Sociedade Brasileira de Melhoramento Animal, 1996. p.204- 208.

REED, C. A. The beginnings of the animal domestication. In: MASON, I. L. (Ed). Evolution of domesticated animals. London: Longman, 1984. p 1-6.

REGITANO, L. C. A. Polimorfismo de proteínas e de DNA em equínos. Piracicaba, 1991. 85p. Dissertação (Mestrado) - Escola Superior de Agricultura "Luiz de Queiroz", Universidade de São Paulo. 
REICHMANN, K. G.; DRINKWATER, R. D.; HETZEL, D. J. S. et al. Generalised glycogenosis (Pompe's disease) in Brhman cattle. A review of the Syndrome and its control in Australia. In: WORLD CONGRESS ON GENETICS APPLIED TO LIVESTOCK PRODUCTION, 5., Guelph, 1994. Proceedings. Guelph: University of Guelph, Dept ${ }^{\circ}$ Animal and Poultry Science, 1994. v. 21, p.165- 168.

ROBINSON, J. L.; HEALY, P. J. Detection of a deletion in the last intron of bovine factor XI. In: WORLD CONGRESS ON GENETICS APPLIED TO LIVESTOCK PRODUCTION, 5., Guelph, 1994. Proceedings. Guelph: University of Guelph, Dept ${ }^{\circ}$ Animal and Poultry Science, 1994. v. 21, p.183- 184.

ROCHA, J. L.; BAKER, J. F.; WOMACK, J. E. et al. Statistical associations between restriction fragment length polymorphisms and quantitative traits in beef cattle. Journal of Animal Science, v. 70, p. 3360-3370, 1992.

ROCHA, J. L.; SANDERS, J. O.; TAYLOR, J. F. Genetic markers to manipulate QTL: The additive illusion. In: ANNUAL MEETING OF THE AMERICAN SOCIETY OF ANIMAL SCIENCE, 72., Minneapolis, 1994. Proceedings. Journal of Animal Science, v. 72 , p. 250, 1994. Suplemento 1.

RON, M.; BAND, M.; WYLER A. et al. Unequivocal determination of sire allele origin for multialleleic microsatellites when only sire and progeny are genotyped. Animal Genetics, v. 24, p. 171-176, 1993.

RON, M.; BLANC, Y.; BAND, M. et al. Misidentification rate in the Israeli dairy cattle population and its implications for genetic improvement. Journal of Dairy Science, v. 79, p. 676-681, 1995.

ROTHSCHILD, M.F.; JACOBSON, C.; VASKE, D.A. et al. A major gene for litter size in pigs. In: WORLD CONGRESS ON GENETICS APPLIED TO LIVESTOCK PRODUCTION, 5., Guelph, 1994. Proceedings. Guelph: University of Guelph, Dept ${ }^{\circ}$ Animal and Poultry Science, 1994. v. 21, p.225- 228.

ROYLE, N. J.; CLARKSON, R. E.; WONG, Z. et al. Clustering of hipervariable minisatellites in the proterminal regions of human autossomes. Genomics, v. 3, p. 352360, 1988.

SAIKI, R. K.; GELFAND, D. H.; STOFFEL, S. et al. Primer-directed enzymatic amplification of DNA with a termostable DNA polimerase. Science, v. 230, p. 13501354, 1988.

SALARU, N. N. R. Paternity investigation among known false trios: $A B O, R h, M N S s$, Duffy, kidd, and HLA systems. Journal of Forensic Sciences, v. 38, p. 1482-1487, 1993. 
SAMBROOCK, J.; FRITSCH, E. F.; MANIATIS, T. Molecular cloning: a laboratory manual. Nova Yok: Cold Spring Harbor, 1989. v. 1.

SAntiago, A. A. A epopéia do Zebu. São Paulo: Empresa Gráfica Carioca. 1960. $559 \mathrm{p}$.

SANTIAGO, A. A. O Zebu na Índia, no Brasil e no Mundo. Campinas: Instituto Campineiro de Ensino Agrícola, 1985. 774p.

SANTOS, R. A saga do Zebu e seus pioneiros. Uberara: Agropecuária Tropical, 1991. p. 167- 202.

SANTOS, R. Nelore: a vitória brasileira. Uberaba: Agropecuária Tropical,1995. v. 2, 392p.

SAX, F. The association of size differences with seed-coat pattern and pigmentation in Phaseolus vulgaris. Genetics, v. 8, p. 552-560, 1923.

SCHLEE, P.; GRAML, R.; SCHALENBERGER, E. et al. Growth hormone and insulinelike growth factor I concentrations in bulls of various growth hormone genotypes. Theoretical and Applied Genetics, v. 88, p. 497-500, 1994.

SCHMUTZ, S. M.; MARQUESS, F. L. S.; BERRYERE, T. G. et al. DNA markerassisted selection of the polled condition in Charolais cattle. Mammalian Genome, v. 6, p. 710-713, 1995.

SCHULER, G.D.; BOGUSKI, M. S.; STEWART, E. A. et al. A gene map of the human genome. Science, v. 274, p. 540- 548, 1996.

SCHWENGER, B.; SCHÓBER, S.; SIMON, D. DUMPS cattle carry a point mutation in the uridine monophosphate synthase gene. Genomics, v. 16, p. 241-244, 1993.

SCHWERIN, M.; BROCKMANN, G.; VANSELOW, J. et al. Perspectives of molecular genome analysis in livestock improvemen- An overview. Animal Research and Development, v. 42, p. 15-26, 1995.

SHANKS, R. D.; HUANG, Y. C.; ROBINSON, J. L. Citrullinemia, marker for economically important traits. In: WORLD CONGRESS ON GENETICS APPLIED TO LIVESTOCK PRODUCTION, 5., Guelph, 1994. Proceedings. Guelph: University of Guelph, Dept ${ }^{\circ}$ Animal and Poultry Science, 1994. v. 19, p.319- 322.

SHUSTER, D.E.; KEHRLI, M.E.; ACKERMANN, M.R. et al. A prevalent mutation responsible for leukocyte adhesion deficiency in Holstein cattle. Proceedings of the National Academy of Science, v. 89, p. 9925-9929, 1992. 
SILVA, L. O. C. Programa de avaliação de touros jovens. In: SIMPÓSIO NACIONAL DE MELHORAMENTO ANIMAL, 1., Ribeirão Preto, 1996. Anais. Viçosa: Sociedade Brasileira de Melhoramento Animal, 1996. p.172- 175.

SIMPSON, G. G. Artiodactyls. In: ANDERSON, S. E JONES, J. K., JR (Ed). Orders and families of recent mammals of the word. New York: John Wiley, 1984. p. 563588 .

SIMPSON, E.R.; MAHENDROO, M.S.; MEANS, G.D. et al. Aromatase cytochrome P450, the enzyme responsible for extrogen biosynthesis. Endocrine Reviews, v. 15, p. 342-355, 1994.

SMITH, C. A. B. Chi-squared tests with small numbers. Human Genetics, v. 50, p. 163-167, 1986.

SMITH, C.; SMITH, D. B. The need for close linkages in marker-assisted selection for economic merit in livestock. Animal Breeding Abstracts, v. 61, n. 4, p. 197-204, 1993.

SOLLER, M. Genetic mapping of the bovine genome using deoxyribonucleic acid-level markers to identify loci affecting quantitative traits of economic importance. Jounal of Dairy Science, v. 73, p. 2628-2646, 1990.

SOLLER, M.; BECKMAN, J. S. Genetic polymorphism in varietal identification and genetic improvement. Theoretical and Applied Genetics, v. 67, p. 25-33, 1983.

SOURTHERN, E. M. Detection of specific sequences among DNA fragments separated by gel electrophoresis. Journal of Molecular Biology, v. 98, p. 503-517, 1975.

STEFFEN, P.; EGGEN, A.; DIETZ, A.B. et al. Isolation and mapping of polymorphic microsatellites in cattle. Animal Genetics, v. 24, p. 121-124, 1993.

TAKAHATA, N.; NEI, M. Allelic genealogy under overdominant and frequencydependent selection and polymorphism of major histocompatibility complex loci. Genetics, v. 124, p. 967-978, 1990.

TANKSLEY, S. D. Mapping Polygenes. Annual Review of Genetics, v. 27, p. 205233, 1993.

TANKSLEY, S. D.; RICK, C. M. Isozymic gene linkage map of the tomato: applications in genetics and breeding. Theoretical and Applied Genetics, v. 57, p. 161-170, 1980.

TAUTZ, D. Hypervariability of simple sequences as a general source for polymorphic DNA markers. Nucleic Acids Research, v. 17, p. 6463-6471, 1989. 
TEALE, A.J.; WAMBUGU, J.; GWAKISA, P.S. et al. A polymorphism in randomly amplified DNA that differentiates the Y chromosomes of Bos indicus and Bos taurus. Animal Genetics, v. 26, p. 243-248, 1995.

THREADGILLL, D. W.; WOMACK, J. E. Synteny mapping of human chromossome 8 loci in cattle. Animal Genetics, v. 22, p. 117-122, 1994.

THUE, T. D.; SCHMUTZ, L. Localization of somatostatin to bovine chromosome 1q23q25 by in situ hybridization. In: WORLD CONGRESS ON GENETICS APPLIED TO LIVESTOCK PRODUCTION, 5., Guelph, 1994. Proceedings. Guelph: University of Guelph, Dept ${ }^{\circ}$ Animal and Poultry Science, 1994. v. 21, p. 60- 62.

USHA, A. P.; SIMPSON, S. P.; WILLIANS, J. L. Probability of randon sire exclusion using microsatellites markers for parentage verification. Animal Genetics, v. 26, p. 155-161, 1995.

VAIMAN, D.; MERCIER, D.; MOAZAMI-GOUDARZI, K. et al. A set of 99 cattle microsatéllite: characterization, synteny mapping and polymorphism. Mammalian Genome, v. 5, p. 288-297, 1994.

VAIMAN, D.; EGGEN, A.; MERCIER, D. et al. A genetic and physical map of bovine chromosome 3. Animal Genetics, v. 26, p. 21-25, 1995.

VANKAN, D. M.; MOORE, S. S.; BELL, K. et al. Evaluation of DNA microsatellites for parentage and paternity testing in cattle. In: CONFERENCE OF THE INTERNATIONAL SOCIETY FOR ANIMAL GENETICS, 24., Prague, 1994. Proceedings. Animal Genetics, v. 25, p. 41, dec.1994, Suplement 2.

VAN VLECK, L. D. Misidentification and sire evaluation. Journal of Dairy Science, v. 53, p. 1697-1703, 1970.

VELMALA, R.; VILKKI, J.; ELO, K. et al. Casein haplotypes and their association with milk production traits in the Finnish Ayrshire cattle. Animal Genetics, v. 26, p. 419425, 1995.

XU, A.; VAN EIJK.; PARK, C. et al. Polymorphism in BoLA-DRB 3 exon 2 correlates with resistance to persistent lynphocytosis caused by bovine leukemia virus. Journal of Immunology, v. 151, p. 6977-6988, 1993.

WAINRIGTH, P. O.; HINKLE, G.; SOGIN, M. L. et al. Monophyletic origen of metazoa evolutionary link with fungi. Science, v. 260, p. 340-342, 1993. 
WEBER J. L.; MAY, P. E. Abundant class of human DNA polymorphisms which can be typed using the polymerase chain reaction. American Journal of Human Genetics, v. 44 , p. $389-396,1989$.

WEIR, B. S. Genetic data analysis: methods for discrete population genetic data. Massachussets: Sinauer Associates, 1990. 377p.

WELLER, J. I.; KASHI, Y ; SOLLER, M. Power of "daughter" and "granddaughter" designs for determining linkage between marker loci and quantitative trait loci in dairy cattle. Journal of Dairy Science, v. 73, p. 252-2537, 1990.

WELSH, J.; McCLELLAND, M. Fingerprinting genomes using PCR with arbitrary primers. Nucleic Acids Research, v. 18, p. 7213-7218, 1990.

WILLIAMS, J.G.K; KUBELIK, A.R.; LIVAK, K.J. et al. DNA polymorphisms amplified by arbitrary primers are useful as genetic markers. Nucleic Acids Research, v. 18, p. 6531-6535, 1990.

WOMACK, J. E.; MOLL, Y. D. Gene map of the cow: conservation of linkage with mouse and man. The Journal of Heredity, v. 77, p. 2-7, 1986.

WONG, Z; WILSON, V.; JEFFREYS, A. J. et al. Cloning a selected fragment from a human DNA "fngerprinting": isolation of highly polymorphic minisatellite. Nucleic Acids Research, v. 14, p. 4605-4616, 1986.

YOUNG, V. R. Genes, molecules and the manipulation of animal growth: A role for bioquemistry and physiologu. Journal of Animal Science, v. 65, p. 107-127, 1987.

ZAFINDRAJAONA, P. S.; LAUVERGNE, J. J. Comparaison de populations de zébu malgache à l'áide des distances génétiques. Genetics Selection and Evolution, v. 25, p. 373-395. 1993

ZHANG, Y; REDAELLI, L.; CASTIGLIOLI, B. et al. Five polymorphic bovine microsatellite loci: IDVGA-62A, IDVGA-71, IDVGA-82, IDVGA-88, IDVGA-90. Animal Genetics, v. 26, p. 365-367, 1995. 